NBER WORKING PAPER SERIES

\title{
CANARY IN A COAL MINE: \\ INFANT MORTALITY, PROPERTY VALUES, AND TRADEOFFS ASSOCIATED WITH MID-20TH CENTURY AIR POLLUTION
}

\author{
Karen Clay \\ Joshua Lewis \\ Edson Severnini \\ Working Paper 22155 \\ http://www.nber.org/papers/w22155 \\ NATIONAL BUREAU OF ECONOMIC RESEARCH \\ 1050 Massachusetts Avenue \\ Cambridge, MA 02138 \\ April 2016, Revised February 2022
}

We thank Martha Bailey, Antonio Bento, Claudia Goldin, Michael Greenstone, Walker Hanlon, Matthew Kahn, Brian Kovak, Nicolai Kumino, Gary Libecap, Granger Morgan, Joseph Shapiro, Lowell Taylor, and seminar participants at Carnegie Mellon, Oxford, LSE, RAND, UCLA, Warwick, U.S. EPA, Yale, the 2015 NBER Summer Institute (Children, DAE), 3rd Northeast Workshop on Energy Policy and Environmental Economics, 10th Meetings of the Urban Economics Association, 15th Occasional Workshop in Environmental and Resource Economics at UCSB, 27th Conference of the ISEE, 50th Meetings of the CNEH, 3rd Economics of We thank Martha Bailey, Antonio Bento, Janet Currie, Claudia Goldin, Walker Hanlon, Rick Hornbeck, Matthew Kahn, Brian Kovak, Nicolai Kuminoff, Gary Libecap, Granger Morgan, Joseph Shapiro, Lowell Taylor, and seminar participants at Bowdoin, Carnegie Mellon, Oxford, LSE, RAND, UCLA, Vanderbilt, Warwick, Yale, U.S. EPA, the 2015 NBER Summer Institute (Children, DAE), 3rd Northeast Workshop on Energy Policy and Environmental Economics, 10th Meetings of the Urban Economics Association, 15th Occasional Workshop in Environmental and Resource Economics at UCSB, 27th Conference of the ISEE, 50th Meetings of the CNEH, 3rd Economics of Low-Carbon Markets Workshop at USP, 37th Meetings of the Brazilian Econometric Society, the 61th North American Meetings of the RSAI, and the 2015 PAA Meetings for valuable comments and suggestions. The authors gratefully acknowledge financial support from the Center for Electricity Industry Studies, Heinz College, and the Berkman fund at Carnegie Mellon University, from the National Science Foundation Grant SES-1627432, and from the University of Montreal. The views expressed herein are those of the authors and do not necessarily reflect the views of the National Bureau of Economic Research.

NBER working papers are circulated for discussion and comment purposes. They have not been peer-reviewed or been subject to the review by the NBER Board of Directors that accompanies official NBER publications.

(C) 2016 by Karen Clay, Joshua Lewis, and Edson Severnini. All rights reserved. Short sections of text, not to exceed two paragraphs, may be quoted without explicit permission provided that full credit, including $\odot$ notice, is given to the source. 
Canary in a Coal Mine: Infant Mortality, Property Values, and Tradeoffs Associated with

Mid-20th Century Air Pollution

Karen Clay, Joshua Lewis, and Edson Severnini

NBER Working Paper No. 22155

April 2016, Revised February 2022

JEL No. I18,N22,Q52,Q53

\begin{abstract}
Investments in local development and infrastructure projects often generate negative externalities such as pollution. Previous work has either focused on the potential for these investments to stimulate local economic activity or the health costs associated with air pollution. This paper examines the tradeoffs associated with the historical expansion in coal-fired electricity generation in the United States, which fueled local development but produced large amounts of unregulated air pollution. We focus on a highly responsive measure of health tradeoffs: the infant mortality rate. Our analysis leverages newly digitized data on all major coal-fired power plants for the period 1938-1962, and two complementary difference-in-differences strategies based on the opening of power plants and new generating units at existing sites. We find that coal-fired power plants imposed large negative health externalities, which were partially offset by the benefits from local electricity generation. We uncover substantial heterogeneity in these tradeoffs, both across counties and over time. Expansions in coal capacity led to increases in infant mortality in counties with high baseline access to electricity, but had no effect in low-access counties. Initial expansions in coal capacity led to decreases in infant mortality, but subsequent additions led to increases in infant mortality. These evolving tradeoffs highlight the importance of accounting for both current and future payoffs when designing environmental regulation.
\end{abstract}

\author{
Karen Clay \\ Heinz College \\ Carnegie Mellon University \\ 5000 Forbes Avenue \\ Pittsburgh, PA 15213 \\ and NBER \\ kclay@andrew.cmu.edu \\ Joshua Lewis \\ University of Montreal \\ Département de sciences économiques \\ 3150 rue Jean-Brillant \\ Montréal, QC, H3T 1N8 \\ joshua.lewis@umontreal.ca
}

Edson Severnini

H. John Heinz III College

Carnegie Mellon University

4800 Forbes Ave \#2114B

Pittsburgh, PA 15213

and NBER

ersevernini@gmail.com 


\section{Introduction}

Societal investments in local development and infrastructure projects can attract industry, create jobs, and increase local economic activity. But these projects can also generate negative externalities such as local air pollution. Empirical studies have either focused on the potential for these investments to stimulate economic activity or the health costs associated with air pollution. A theoretically grounded assessment of net value includes not only the potential of a project to produce the desired economic outcomes relative to the up-front costs, but also the externalities that are created. Policy analysis in this context can entail complex tradeoffs, since economic beneficiaries will typically differ from those bearing the external costs.

This paper examines the health tradeoffs associated with the historical expansion in coal-fired electricity generation in the United States. The mid-twentieth century witnessed a sharp rise in electricity generated by coal-fired power plants, which fueled local industrial activity, created jobs, and brought electricity to American households, but also produced large amounts of unregulated air pollution. This context provides a unique opportunity to evaluate the local health tradeoffs associated with a large scale investment project. We combine newly digitized detailed data on the location, year of opening, and characteristics of all major coal-fired power plants with annual county-level infant mortality rates for the period 1938-1962. Infants are acutely sensitive to contemporaneous environmental air pollution and the benefits arising from electricity access. Thus the infant mortality rate captures these health tradeoffs, with infants serving as the proverbial "canary in a coal mine".

Our empirical analysis relies on two complementary difference-in-differences estimation strategies. Our first strategy relies on the sharp change in local amenities resulting from new power plant openings in an event-study framework. We compare changes in infant mortality rates between exposed counties to changes in infant mortality rates in counties at slightly further distances that trended similarly along observable characteristics, but which were largely unaffected by either the increase in electricity generation or air pollution. Our 
second strategy relies on variation in local capacity from both new power plant openings and the openings of new generating units at existing sites. We compare relative changes in infant mortality rates across counties exposed to different capacity changes within the same state that trended similarly along a range of baseline observable characteristics.

We combine these two research strategies with several different sources of heterogeneity to shed light on the local health tradeoffs associated with coal-fired generation. First, we exploit heterogeneity in the benefits from coal capacity expansions by comparing the estimates across counties with different baseline access to electricity. Second, we exploit heterogeneity in the pollution costs from power plant emissions. We combine annual information on plant-level coal use with the AP3 air pollution model to measure the dispersion of ambient air pollution around coal-fired plants. ${ }^{1}$ We use these measures to compare the health tradeoffs across counties that benefited similarly from electricity access, but that were exposed to differing concentrations of power plant air pollution. Finally, we exploit the extended 25-year time horizon to examine how the marginal health impacts of new coal capacity installation varied as the existing stock of local generating infrastructure evolved over the sample period.

We find clear evidence of health tradeoffs associated with coal-fired generation. First, we uncover substantial treatment heterogeneity according to baseline electricity access. In counties with low baseline access to electricity, infant mortality was unaffected by coal capacity changes, consistent with the health benefits from increased generation having offset the health costs from air pollution. We also find that hydroelectric capacity - which expanded electricity access, but produced no emissions - led to decreases in infant mortality. In contrast, in high-access counties, coal capacity expansions increased infant mortality significantly.

Second, we find that the net health impacts of coal-fired power plant openings varied systematically with local exposure to plant emissions. In counties with low levels of plant-related

\footnotetext{
${ }^{1}$ The AP3 model links the marginal contribution of emissions in any source county to the ambient concentration in all destination counties (Muller and Mendelsohn, 2007, 2009). This model has been widely used by researchers in economics and environmental sciences (Michalek et al., 2011; Fowlie, Knittel and Wolfram, 2012; Sandler, 2012; Holland et al., 2016; Sanders and Barreca, 2021)
} 
air pollution, the net effect on infant mortality was negative, suggesting that the health benefits from increased electricity generation outweighed the pollution costs. In counties with high levels of plant-related air pollution, the net effect on infant mortality was positive, suggesting that the health costs from increased air pollution outweighed the benefits from electricity infrastructure. We apply the AP3 estimates to examine three counterfactual scenarios in which local exposure to power plant emissions was reduced: increased smokestack height, earlier development of hydro, and use of baghouses, which reduce emissions with fabric filters. All three scenarios would have resulted in a cost per infant life saved that was below the $\$ 1$ million value of a statistical life in 1940 (Costa and Kahn, 2004).

We find that the mid-twentieth century witnessed a remarkable reversal in the relationship between coal-fired generation and infant mortality. Initially, coal-fired generation was associated with net decreases in infant mortality. Later, coal-fired generation was associated with net increases in infant mortality. This reversal was largely driven by a change in the marginal health impact of coal capacity additions as the existing stock of local generating capacity expanded. These patterns are also consistent with health tradeoffs: as the marginal health benefits from further capacity expansions diminished over time, they were overwhelmed by the marginal health damage from unregulated power plant emissions.

We explore a variety of mechanisms that might account for these health tradeoffs, and find that the benefits arose from two channels: increased household access to electricity and increased local economic activity. In low access counties, coal capacity expansions led to increases in the fraction of homes with electricity, running water, and a modern stove. These patterns are consistent with previous research, which has documented the health benefits from electrification (Fishback and Kitchens, 2015; Lewis, 2018). In particular, the literature has emphasized the importance of improved sanitation through access to pumped water and other modern appliances, as well as decreases in household air pollution through the elimination of dirty cooking technologies and kerosene lighting. Indeed, we find that expansions in coal-fired capacity had differentially positive effects on infant health in locations where 
households were more reliant on coal for cooking in the baseline and where there was a higher incidence of sanitation-related mortality. ${ }^{2}$ To assess the second channel, we estimate the effects of coal capacity on a range of local economic outcomes. We find little evidence of a broad expansion in the local economy, as captured by employment, wages, or population demographics. Instead, the effects were concentrated in the manufacturing sector, where expansions in coal-fired capacity stimulated modest employment growth in low access counties, consistent with Kline and Moretti (2014). Taken together, the results suggest that both changes in household technology and local economic development may have contributed to improvements in infant health in low access areas.

Our study brings together and contributes to two distinct literatures - the effects of local economic development projects and the health externalities from air pollution. Previous research has studied the local economic impacts of major infrastructure projects - electricity, industrial development, railways, highways - and typically finds that these investments stimulate economic activity and generate local economic spillovers (Greenstone, Hornbeck and Moretti, 2010; Kline and Moretti, 2014; Donaldson and Hornbeck, 2016; Michaels, 2008). ${ }^{3}$ Nevertheless, the existing literature has focused almost exclusively on the economic impacts of these projects and largely overlooked the negative externalities that can arise, for example, from increased local air pollution. ${ }^{4}$ Our paper is one of the first to document health tradeoffs associated with a major local infrastructure investment: coal-fired power plants. In addition, whereas previous research has focused on estimating average treatment effects of infrastructure investments, we document quantitatively meaningful heterogeneity in net impacts both across counties with different levels of baseline electricity access and different exposure to power plant emissions, with potentially important implications for policy.

\footnotetext{
${ }^{2}$ These findings support evidence on the effects of indoor air pollution both historically and in the current developing countries context (Barreca, Clay and Tarr, 2014; Hanna, Duflo and Greenstone, 2016).

${ }^{3}$ See also Dinkelman (2011), Lipscomb, Mobarak and Barham (2013), Allcott, Collard-Wexler and O'Connell (2016), and Severnini (2014) on electricity; Haines and Margo (2008), Atack et al. (2010), and Donaldson (2018) on railways; and Baum-Snow (2007), and Faber (2014) on highways.

${ }^{4}$ One notable exception is Duflo and Pande (2007), who study the downstream benefits and upstream externalities associated with dam construction in India. They find that the economic benefits from dam construction in downstream districts were offset by higher poverty in upstream districts.
} 
Our paper also contributes to the literature on the health effects of air pollution. There is a well-established literature that documents substantial health costs associated with air pollution (Chay and Greenstone, 2003a; Currie and Neidell, 2005; Currie and Walker, 2011; Schlenker and Walker, 2016; Deryugina et al., 2016). Nevertheless, these studies do not account for potential health benefits associated with polluting activities. Indeed, researchers typically rely on identification strategies aimed at netting out any direct effects of polluting activities. Because major sources of air pollution such as industrial activity and electricity generation may transform local economic conditions and local amenities, it is essential to incorporate any associated benefits when assessing their overall impact on population health. Our paper is among the first to account for these direct benefits when evaluating the effects of a major polluting activity on health. In particular, the mid-twentieth century expansion in coal-fired generation allows us to contrast the benefits from local electricity infrastructure against the costs from unregulated pollution. ${ }^{5}$

The paper proceeds as follows: Section 2 discusses the tradeoffs from mid-twentieth century coal-fired generation. Section 3 describes our data. Section 4 presents our empirical framework. Section 5 reports our findings. Section 6 discusses the AP3 model and the counterfactuals. Section 7 concludes.

\section{Costs and Benefits of Coal-fired Generation}

Coal-fired electricity generation rose substantially during the mid-twentieth century. Figure 1a shows that between 1938 and 1962, the U.S. experienced a seven-fold increase in electricity production, primarily driven by the expansion in coal-fired electricity generation. This expansion was associated with important local tradeoffs: the costs from exposure to unregulated power plant emissions, and the benefits from increased local generating capacity.

\footnotetext{
${ }^{5}$ Our findings complement research by Hanlon (2020), who shows that urban development during Englands Industrial Revolution was substantially constrained by air pollution externalities. Similarly, Bartik et al. (2019) find that the local economic benefits from hydraulic fracking were significantly offset by a deterioration in local amenities.
} 
In this section, we briefly discuss why infant health is a useful indicator of these tradeoffs, and then describe the costs and benefits associated with coal-fired generation in greater detail.

Our analysis of the tradeoffs associated with coal-fired electricity generation focuses on infant health as measured by the infant mortality rate. Infants are acutely sensitive to contemporaneous environmental conditions, and given their young age, concerns regarding unmeasured past exposure are largely mitigated. The infant mortality rate has been widely used to measure the effects of air pollution (Chay and Greenstone, 2003a,b; Currie and Neidell, 2005; Currie et al., 2014). ${ }^{6}$ There is also a growing literature that documents the numerous benefits of electricity access for infant health (Barron and Torero, 2017; Lewis, 2018). Although the costs and benefits of coal-fired generation may accrue to other age groups, the infant mortality rate provides a highly responsive summary measure of the local tradeoffs. $^{7}$

Coal-fired power plants were an important contributor to air pollution. ${ }^{8}$ Figure $1 \mathrm{~b}$ plots the share of domestic coal consumption by electric utilities from 1938 to 1962. The share increased from 15 to 54 percent, as other uses such as coal for home heating and coal for railways declined.

Air pollution from coal-fired power plants was locally concentrated. Figure 2 plots the differential concentration of airborne sulfates, as measured by the AP3 model based on annual coal consumption by coal-fired power plants observed in our data. ${ }^{9}$ The concentration of

\footnotetext{
${ }^{6}$ Infant health is affected by air pollution through both prenatal exposure (Currie and Walker, 2011), and postnatal exposure (Woodruff, Darrow and Parker, 2008; Arceo, Hanna and Oliva, 2016).

${ }^{7}$ Unlike effects on all-age mortality, which may be concentrated among individuals who were very ill (Spix et al., 1993; Lipfert and Wyzga, 1995), results found for infant mortality are also likely to represent meaningful impacts for life expectancy, which has been another outcome of interest in recent studies (Chen et al., 2013; Ebenstein et al., 2017).

${ }^{8}$ Monitoring of air pollution was rare before the $1950 \mathrm{~s}$, but sporadic readings during the first half of the twentieth century suggest that air pollution was severe and comparable to levels found in cities in developing countries today (see Appendix Table A.1). Data for a sample of 85 counties from 1957-1962 also show a strong relationship between local coal-fired capacity and TSP concentrations (Appendix Table A.4).

${ }^{9}$ Sulfur dioxide emissions are a marker for the pollution produced by coal-fired power plants. Sulfates are an important component of particulate matter, and are derived principally from atmospheric transformations of gaseous sulfur dioxide. See Appendix B.3 for details on the air quality modelling based on the AP3 model, as well as the data and the steps to obtain our measure of airborne sulfates.
} 
airborne sulfates declines gradually up to 30 miles from a power plant, drops sharply at this threshold, and remains at a similar level up to 90 miles. This dispersion pattern motivates our estimation strategy, which compares counties within 30 miles of a coal-fired plant to counties slightly farther away. ${ }^{10}$

Prior to the passage of the 1963 Clean Air Act, electric utilities did little to mitigate the consequences of air pollution. Experimentation with scrubbing did not begin until the late 1960s in the United States (Biondo and Marten, 1977). Figure A.2 shows that the height of power plant smokestacks - a key determinant of pollutant dispersion - was relatively constant from 1938 to 1962 and considerably below current levels. The sole mitigation of pollution came from siting larger plants farther from population centers, as advances in transmission technology allowed electricity to be shipped over longer distances.

Decisions regarding the siting of large coal-fired power plants were heavily influenced by local geographic conditions, and a desire to develop an interconnected power grid across multiple urban areas (Hughes, 1993; Casazza, 1993). ${ }^{11}$ New plant openings were opened primarily to meet industrial demand, whereas household electricity consumption represented only a small fraction of total plant generation. Nevertheless, proximity to power plants played a critical role in determining whether households electrified, due to the costs associated with extending services. ${ }^{12}$

Household access to electricity brought direct benefits to infant health (Lewis, 2018). Electric lights replaced kerosene lamps, which were highly polluting (Lam et al., 2012; Barron and Torero, 2017). The substitution of modern ranges for coal and wood cookstoves also contributed to a better household air quality. ${ }^{13}$ Although less harmful than open hearth

\footnotetext{
${ }^{10}$ Appendix Figure A.1 also plots the average density of PM2.5 by distance to the source, based on nine power plants in Illinois in 1988 (Levy et al., 2002). Virtually all exposure was concentrated within 30 miles of plant: the average resident within 30 miles was exposed to concentrations that were 11 times greater than the average resident located between 30 and 90 miles from a plant.This dispersion pattern is similar to more recent estimates conducted by the EPA (EPA, 2011).

${ }^{11}$ Hughes (1993, p.370) argues that the primary motivation in siting was "massing generating units near economical sources of energy and near cooling water, and transmitting electricity to load centers" using high voltage lines.

${ }^{12}$ Proximity to the grid was also a key determinant of loan approval under the REA.

${ }^{13}$ In 1940, only 5.4 percent of the households had electric ranges. That percentage increased considerably
} 
cooking, as is common in many developing countries today, properly ventilated coal and wood stoves still produce substantial amounts of residential air pollution (Evans et al., 2002; Hanna, Duflo and Greenstone, 2016).

Electricity also brought access to a range of new household technologies that indirectly benefited infant health. In rural areas, electric pumps brought access to indoor water, which improved household hygiene and greatly reduced the time-cost and physical ardor of housework. ${ }^{14}$ Modern appliances, such as vacuum cleaners, electric ranges, and washing machines also reduced the time required for basic housework, which allowed women to reallocate time to activities that promoted child health (Mokyr, 2000). Many modern technologies also brought improvements to home sanitation (Wilson, 1929; Meckel, 1990). The diffusion of washing machines led to more frequent laundering, including of diapers. Access to pumped water allowed for hygienic food preparation, increased hand washing, and sterilization of bottles. Refrigerators reduced exposure to food-borne bacteria.

Expansions in coal-fired electricity generation may have improved infant health indirectly through their impact on local economic conditions (Hoynes, Miller and Simon, 2015). Increased local electricity infrastructure may have stimulated growth in the manufacturing industry (Lipscomb, Mobarak and Barham, 2013; Kline and Moretti, 2014). Rural electrifiaction may have also increased higher agricultural revenue (Rud, 2012; Fishback and Kitchens, 2015; Lewis and Severnini, 2020).

Figure 3 illustrates the benefit-cost tradeoffs of increased coal-fired electricity generation as a function of current generating capacity. ${ }^{15}$ In the absence of pollution abatement, expansions in coal-fired capacity should have similar effects on local air quality, independent of pre-existing generating capacity. In contrast, as local generating capacity increases, the

to 15 in 1950 and 30.8 in 1960 (USBC, 1963, p. XL, Table U). This increase mirrored the decline of wood cookstoves, which decreased from 23.6 in 1940 to 9.9 in 1950 to 2.7 percent in 1960, and coal cookstoves, which decreased from 11.5 percent in 1940 to 7.8 percent in 1950 to 1.1 percent in 1960 (USBC, 1963, p. XL, Table U).

${ }^{14} \mathrm{~A}$ study of a half-million farm households found that without electricity, the average family used 1,400 gallons of well-drawn water per week, and spent more than 10 hours in water collection (Luff, 1940, p.9).

${ }^{15}$ In Appendix B.1, we present the microfoundations for this tradeoff. 
marginal benefits from further capacity additions should decrease as the scope to expand electricity access diminishes. Together, the constant marginal cost and decreasing marginal benefit curve result in the inverted-U relationship between coal-fired capacity and infant mortality: at low levels of local access, expansions in capacity should tend to decrease infant mortality; at high levels of access, expansions in capacity should tend to increase infant mortality.

This simple framework highlights two ways in which the effects of coal-fired capacity are expected to vary. First, comparing across localities, expansions in coal-fired capacity should have more negative or less positive effects on infant health in places that had more generating capacity in the baseline period. Second, comparing within localities, expansions in coal-fired capacity should have more negative or less positive effects on infant health over time, since the diminishing marginal benefits from continued expansion is more likely to be overwhelmed by the constant marginal pollution costs. We explore these two predictions in the empirical analysis.

\section{Data}

To study the effects of coal-fired power plants on infant mortality, we digitized annual information on location, nameplate capacity, electricity generation, fuel consumption, first year of operation, and other characteristics of power plants that operated during the period 1938 to 1962. In 1938, the Federal Power Commission began collecting detailed annual information on roughly 500 of the largest steam-electric power plants, representing over 90 percent of all coal-fired electricity generation nationwide (FPC, 1947, 1948-62, 1963). These data allow us to identify 270 coal-fired power plants that opened between 1938 and 1962, and more than 1,000 new generating unit openings at existing sites. For more detail on the power plant data construction, see Appendix B.2.

Our main outcome variable is the infant mortality rate per 1,000 live births. These 
data are drawn from annual volumes of the Vital Statistics of the United States. ${ }^{16}$ Figure A.7 displays trends in infant mortality, which decreased substantially from 1938 to 1962, particularly prior to 1950 .

The analysis includes controls for a range of county level characteristics. County-level data for decadal years 1940, 1950, and 1960 are from the Census of Housing and Population and the Census of Manufactures (Haines and ICPSR, 2010; USDOC and ICPSR, 2012). These data include total and manufacturing employment, total population, manufacturing and retail payroll per worker, median dwelling rent, percentage of whites, and percentage of population aged at least 25 years with a high school degree. Data on whether a county was recommended to receive a highway from the 1944 Interstate Highway System Plan are from Baum-Snow (2007) and Michaels (2008), and data on the total mileage of rail tracks in a county in 1911 are from Atack (2016). Data on annual county climatic conditions are from the National Oceanic and Atmospheric Administration (NOAA). These data include annual precipitation, average temperature, degree days below 10 degrees Celsius, and degree days above 29 degrees Celsius.

Summary statistics are reported in Appendix Tables A.2 and A.3.

\section{Empirical Strategy}

\subsection{Analysis based on Coal-fired Power Plant Openings}

The first research strategy is based on estimating average changes in infant mortality in counties 'near' a coal-fired power plant relative to changes in infant mortality in counties located slightly farther away before and after the plant opening. We define counties within 30 miles of a power plant as treatment counties, and counties 30 to 90 miles from a plant

\footnotetext{
${ }^{16}$ Fishback et al. (n.d.) generously provided the data from 1938-1951. We digitized additional data for the period 1952-1958 (USHEW, 1952-1958b), and assembled the available microdata at the county level for the period 1959-1962 from the NBER Public Use Data Archive. These data are now available at ICPSR (Bailey et al., 2016).
} 
as control counties, based on the dispersion of particulate matter around coal-fired power plants (see Figure 2). ${ }^{17}$

We estimate the following regression model:

$$
\begin{aligned}
\text { IMR }_{c p t} & =\alpha+\beta \cdot 1[\text { PPOperating }]_{p t}+\delta \cdot\left(1[\text { PPOperating }]_{p t} \times 1[\text { Near }]_{c p}\right) \\
& +\psi X_{c p t}+\theta \cdot\left(Z_{c p} \times t\right)+\eta_{c p}+\lambda_{s t}+\epsilon_{c p t}
\end{aligned}
$$

where $I M R_{c p t}$ denotes infant mortality rate in county $c$ associated with plant $p$ in year $t$. For each plant, there are two types of observations per year: treatment counties (within 30 miles of the plant) and control counties (30-90 miles from the plant). ${ }^{18}$ This is a "stacked difference-in-differences" approach in which each treatment area and timing are defined in isolation, but then all the event-specific data sets are stacked to run the analysis and obtain an average treatment effect across all plant openings. Each data set has both treatment and control groups, and only counties that were not treated within the sample window are allowed to be controls. ${ }^{19}$

The variable $1[\text { PPOperating }]_{p t}$ is an indicator for whether plant $p$ is operating in year $t$, and $1[\text { Near }]_{c p}$ is equal to one for counties within 30 miles of a plant site. The model includes a vector of county-plant pair fixed effects, $\eta_{c p}$, to control for time-invariant determinants of infant mortality at a given distance from each plant. ${ }^{20}$ It also includes a vector of state-by-year fixed effects, $\lambda_{s t}$, to control for state-level trends in infant mortality. The term $\left(Z_{c p} \times t\right)$ denotes a vector of time trends based on geographic characteristics (county-centroid

\footnotetext{
${ }^{17}$ Figure A.3 depicts the 1,969 counties that form the basis of the analysis, with the dark grey shade identifying treatment counties and white representing control counties.

${ }^{18}$ In the robustness checks, we exclude counties located 30 to 60 miles from a plant to alleviate concerns regarding spatial spillovers.

${ }^{19}$ Our approach is similar to Cengiz et al. (2019). Because it relies on a more stringent criteria for the inclusion control observations than the standard two-way fixed effects DD, the approach limits concerns regarding the identifying sources of variation discussed in Goodman-Bacon (2021). Specifically, each treatment event is estimated based on control observations that are never treated throughout the entire event-time horizon.

${ }^{20} \mathrm{In}$ practice, the treatment indicator, $1[\mathrm{Near}]_{c p}$, is collinear the county-plant pair fixed effects, $\eta_{c p}$, so it is suppressed from equation (1).
} 
longitude and latitude), baseline economic conditions (log of population, employment, and manufacturing employment, all measured in 1940), transportation infrastructure (an indicator for whether a county was recommended to receive a highway from the 1944 Interstate Highway System Plan, the total mileage of rail tracks in 1911), and the fraction of households with electric lighting in 1940. $X_{c p t}$ denotes a vector of time-varying controls for hydroelectric capacity, and climatic covariates that may have influenced the dispersion of pollutants including annual precipitation, average temperature, degree days below 10 degrees Celsius, and degree days above 29 degrees Celsius. Equation (1) includes two additional research design covariates: (i) A time trend based on the distance between the county centroid and power plant. This variable ensures that identification is based on sharp changes in infant mortality following a power plant opening, rather than differential trends in outcomes based on power plant distance. (ii) Annual nameplate capacity of each coal-fired power plant. This variable ensures that all estimates capture the impact of an average sized power plant opening, so that treatment heterogeneity cannot be attributed to differences in the size of plants that opened in different locations or at different points in times.

The coefficient of interest, $\delta$, captures the average change in the infant mortality rate following a coal-fired power plant opening in counties within 30 miles, relative to the average change in counties 30 to 90 miles away. The inclusion of the county-plant pair fixed effects, $\eta_{c p}$, ensures that $\delta$ is identified solely by the timing of the opening of power plants. Our identifying assumption is that infant mortality would have trended similarly in counties nearer and farther from a particular plant site in the absence of opening. In practice, this assumption must hold after allowing for differential trends according to baseline characteristics. We assess the validity of the approach in the next section.

The average treatment effect captured by $\delta$ may mask substantial treatment heterogeneity. Given the absence of abatement efforts, the local costs of coal-fired power plant emissions were likely to have been similar across localities. Nevertheless, the benefits from increased coal-fired generation may have differed based on pre-existing electricity infrastructure. To 
explore this potential treatment heterogeneity, we classify counties according to two measures of baseline electricity access: total baseline (coal and hydro) generating capacity within 30 miles in 1940, and the fraction of households with electricity in the baseline (reported in the 1940 census of population). We classify counties as either low (L) or high (H) access according to whether they had below- or above-median values. We then estimate generalized versions of equation (1), in which the effects of power plant openings $\left(\delta_{L}\right.$ and $\left.\delta_{H}\right)$ are allowed to differ across the two groups. These models allow us to explore underlying heterogeneity in the treatment effects according to pre-existing electricity infrastructure.

Two additional estimation details are worth nothing. First, all regressions are weighted by the number of live births. Second, robust standard errors are clustered at the county-level to adjust for heteroskedasticity and within-county serial correlation. ${ }^{21}$

\subsection{Analysis Based on Local Variation in Coal-fired Capacity}

Our second empirical strategy relies on local variation in coal-fired capacity driven by both new power plant openings and the opening of new generating units at existing facilities. This research approach offers several advantages over the 'event-study' design. Because the analysis relies on changes in coal-fired capacity due to both new power plant openings and openings of generating units at existing facilities, there is substantially more variation. The opening of new generating units at existing sites accounted for more than 80 percent of the nationwide expansion in coal-fired generating capacity from 1938 to 1962 (Figure 6a), and there were 10 times more capacity upgrades than new plant openings (Figure 6b). This additional variation allows us to identify effects over a larger sample of counties, rather than just those exposed to a plant opening. The richer variation in coal capacity also enables us to explore treatment dynamics over an extended 25-year time horizon. Figure A.4 displays the 2,027 sample counties within 90 miles of a coal-fired power plant by the end of our sample period. Counties are shaded according to the change in coal-fired capacity from 1938 to

\footnotetext{
${ }^{21}$ Similar results are found when standard errors are clustered at the plant level.
} 
1962, darker shades indicating larger increases in capacity.

We adopt a continuous difference-in-differences framework, comparing changes in outcomes in counties 'near' a capacity change to changes in outcomes in counties not exposed to a capacity change. Formally, we estimate the following regression model:

$$
I M R_{c t}=\alpha+\beta \cdot \text { CoalCapacity }_{c t}+\psi X_{c t}+\theta_{t} Z_{c}+\eta_{c}+\lambda_{t}+\epsilon_{c t} .
$$

where $I M R_{c t}$ denotes the infant mortality rate in county $c$ in year $t$. The model includes county fixed effects, $\eta_{c}$, and state-by-year fixed effects, $\lambda_{s t}$, to account for state-level trends in infant health. Both the time varying covariates, $X_{c t}$, and the time trends based on the invariant covariates, $Z_{c}$, are the same as those described in equation (1). The main explanatory variable, CoalCapacityct, denotes coal-fired capacity within 30 miles of the county centroid.

The coefficient of interest, $\beta$, captures the average change in the infant mortality rate in counties within 30 miles of a capacity change, relative to the average change in infant mortality in counties within the same state that did not experience a capacity change. We estimate both the average treatment effect, $\beta$, and the heterogenous treatment effects $\left(\beta_{L}\right.$ and $\beta_{H}$ ), based on generalized versions of equation (2) that allow for treatment heterogeneity according to baseline generating capacity, and baseline household electricity access. We also estimate the evolving treatment effects based on generalized versions of equation (2) that allow for heterogeneity according to the timing of the openings and expansions of electricity generating capacity.

The identifying assumption requires that counties within the same state with similar baseline characteristics would have experienced similar trends in infant mortality in the absence of coal capacity changes. The local exogeneity of coal-fired capacity is supported by the conclusions of historians of the power industry, who emphasize that geographical constraints and the incentive to develop an interconnected grid were the primary determinants of power 
plant investment decisions, rather than local demand. For example, Hughes (1993) argues that electric utilities were "massing generating units near economic sources of energy and near cooling water, and transmitting electricity to load centers" (p. 270) using high voltage transmission lines. We explore this question in more detail in the next section.

\section{Results}

\subsection{Coal-fired Power Plant Openings and Infant Mortality}

To motivate the regression analysis, and evaluate the validity of the common trends assumption of the difference-in-differences strategy, we first present event study graphs based on the timing of power plant openings. These graphs are based on a generalized version of equation (1), that allows the coefficients $\delta$ to vary with event time $t \in\{-10,6\} .{ }^{22}$ We distinguish three time periods: prior to power plant construction, $t \in\{-10,-5\}$, likely construction, $t \in\{-4,0\}$, and post-opening, $t \in\{1,6\} .{ }^{23}$ To examine both the costs of air pollution and the benefits of increased generating capacity, we report the estimates separately across counties that had above- and below-median generating capacity in 1940 .

Figures 5a and 5b report the event study graphs. The estimates support the underlying research design. In both high- and low-capacity counties, there is no evidence of differential pre-trends in infant mortality. ${ }^{24}$ Throughout the five-year period prior to plant construction, infant mortality rates trended similarly in both treatment and control counties. From $t \in$ $\{-4,0\}$, infant mortality rates rose modestly in treatment counties, consistent with increased air pollution from plant construction.

\footnotetext{
${ }^{22}$ Following Kline (2012), we estimate equation (1) for the period $t \in\{-11,7\}$ but suppress the endpoint coefficients, which place unequal weight on power plants that opened early or late in the sample period. Results based on a shorter time horizon are similar in both magnitude and significance.

${ }^{23}$ The Federal Power Commission reports cite construction times ranging from two to four years, although they do not specify the construction period by plant. During construction, local air quality was substantially impacted by dust, equipment exhaust, and burning emissions (EPA, 1999, p1-1). Since we lack information on the exact month of opening, period $t=0$ is assigned to the pre-opening period.

${ }^{24}$ Graphs for the overall effects, and by baseline household electricity access are reported in Figures A.5 and A.6, and show little evidence of pre-trends in infant mortality.
} 
Figures $5 \mathrm{a}$ and $5 \mathrm{~b}$ show striking differences in infant mortality rates post-opening. In counties with high baseline generation capacity, power plant openings are associated with increases in mortality. The relative infant mortality rate rose sharply in the first full year of power plant operation, and the gap widened with time. The timing of these increases coincides with the annual changes in power plant coal consumption post opening (Figure A.7). These results are consistent with the health costs from increased pollution having outweighed the marginal benefits from increased generating capacity. In contrast, in counties with low baseline generating capacity, there was a sharp decrease in infant mortality beginning two years after a plant opening, suggesting that the benefits from increased electricity generation overwhelmed the pollution costs.

Table 1 presents the regression estimates from the difference-in-differences estimation strategy based on new power plant openings. ${ }^{25}$ Column 1 includes county-plant pair fixed effects, state-by-year fixed effects, and geographic controls. Column 2 includes controls for 1940 manufacturing employment interacted with a time trend to allow for differential trends in mortality according to the initial size of the manufacturing sector, a competing source of air pollution. The last column includes the full set of controls in equation (1).

Power plant openings led to a net increase in infant mortality. Across all three specifications in Panel A, the point estimates are positive and statistically significant. The inclusion of county covariates reduces the estimates somewhat, consistent with trends in infant mortality according to initial manufacturing employment and local infrastructure over the 25-year period. ${ }^{26}$ Our preferred point estimates in column 3 imply that an operating power plant is associated with an increase of 0.6 additional infant deaths per 1,000 live births in 'nearby' counties per year of operation, a 2.1 percent increase in the infant mortality rate. ${ }^{27}$

\footnotetext{
${ }^{25}$ We conservatively set $t=-1$ as the reference year in all regressions. Given the modest rise in infant mortality during construction in Figures $5 \mathrm{a}$ and $5 \mathrm{~b}$, the coefficient estimates reflect a lower bound for the health damage attributable to power plant openings.

${ }^{26}$ The event study design exploits sharp changes in the immediate aftermath of a plant opening, rather than these long-run secular trends (see Figure A.5).

${ }^{27}$ This result was found by dividing the estimated coefficient by the average infant mortality rate in the 'nearby' counties in our 'event-study' sample $(2.1=0.609 / 29.1)$. For comparison, the current infant mortality rate in the United States is roughly 6 infant deaths per 1,000 live births.
} 
Next, we explore heterogeneity in the mortality tradeoffs according to initial county characteristics. We estimate generalized versions of equation (1) that allow the coefficient estimates to differ according to generating capacity in 1940 in Panel B, and the fraction of households with electricity in 1940 in Panel C. ${ }^{28}$ The results show that the impact of coal-fired power plant openings on infant mortality was larger in places with more preexisting electricity infrastructure. In low access counties, whether measured by baseline generating capacity or the fraction of households with electricity, power plant openings had no significant impact on mortality rates, and the point estimates are generally negative. These results are striking, given the sharp increase in coal-fired emissions post-opening and the strong link between air pollution and infant mortality. The findings are consistent with the health benefits from increased electricity generation having offset the pollution costs. In contrast, in counties with high baseline access, power plant openings are associated with large and significant increases in infant mortality, consistent with the pollution costs having overwhelmed the marginal health benefits from increased electricity generation. In all four specifications, the hypothesis that the coefficients are equal is rejected.

Appendix Table A.5 shows the results are robust to a range of alternative specifications. The effects are similar in regressions that are weighted by live births (col. 2) and regressions that exclude counites treated by multiple plant openings (col. 3). We next explore the sensitivity of the results to the 30-mile cutoff. Although pollution was locally concentrated, the benefits of increased electricity access likely extended beyond 30 miles. To explore this issue, column 4 reports estimates from regressions that exclude counties located 30 to 60 miles from a power plant. The results are similar, albeit somewhat less positive, suggesting that the benefits extended beyond the 30 mile radius. In columns 5-6, we further explore the sensitivity of the results to alternate distance cutoffs. The results are qualitatively similar. In column 7 , we find similar reuslts based on log infant mortality. In the final two columns we further evaluate whether air pollution is the underlying determinant of the mortality

\footnotetext{
${ }^{28}$ The cross-county correlation baseline generating capacity and the fraction of households with electricity in 1940 is 0.4 .
} 
increases. Column 8 allows the estimated impacts of plant openings to vary according to power plant size. The results show that the negative effects on infant health were driven by large power plants. ${ }^{29}$ In column 9, we allow the effects of power plant openings to vary according to whether counties were downwind from plants. The estimated effects are systematically larger in downwind counties. ${ }^{30,31}$

\subsection{Coal Capacity and Infant Mortality}

In this section, we use variation in both new plant openings and expansions at existing sites to identify the impact of coal-fired generation on infant mortality over a larger sample of counties, and to explore the evolving effects over an extended 25-year time horizon. Analogous to the 'event-study' design, the empirical approach compares changes in outcomes in counties 'near' a capacity change to changes in outcomes in counties not exposed to a capacity change.

The identifying assumption that infant mortality would have trended similarly in the absence of capacity additions is supported by two pieces of evidence. First, Figure 6b shows that the size of new generating units at existing sites was comparable to initial capacity at plant openings. This is an indication of the common features in the decision making process (Cirillo et al., 1977). It also suggests that the parallel trends assumption underlying the 'event-study' analysis will continue to hold. Second, there is little evidence that pre-trends

\footnotetext{
${ }^{29}$ Large power plants may also have differentially benefited infant health through greater electricity generation post-opening, although the amount of electricity required to meet household demand could easily have been met by the smaller plants.

${ }^{30}$ Appendix Table A.6 also reports the results of Oster tests to investigate the robustness of the significant estimates in Table 1, column 3 to omitted variables bias Oster (2019). We find $\delta$ estimates that are all negative, which implies that the covariance between observables and treatment status has the opposite sign as the covariance between unobservables and treatment status. Together the estimates imply that additional controls strengthen the effect magnitudes, suggesting that the significant effects cannot be attributable to omitted variables bias.

${ }^{31}$ We also conduct a Goodman-Bacon (2021) decomposition for the generalized difference-in-differences model without any control variables, and find that over 90 percent of the identifying variation comes from the comparison between ever treated and never treated units. Even when we include all the controls from our preferred specification, roughly one third of the identifying variation arises from ever treated versus never treated comparison. These findings suggest that the staggered nature of our treatment causes does not cause substantial biases.
} 
in county socioeconomic conditions predict subsequent capacity expansions. Table 2 reports the relationship between baseline county characteristics and within-state capacity changes from 1938 to 1962. Although capacity expansions appear to be related to 1940 levels of county socioeconomic conditions, changes in those socioeconomic conditions from 1930 to 1940 have very little predictive power for subsequent capacity changes. ${ }^{32}$

Table 3, Panel A, reports the net effects of coal capacity on infant mortality. Across all three specifications, the point estimates are positive and statistically significant. Our preferred estimates in column 3 imply that a one standard deviation increase in coal capacity is associated with roughly 2 additional infant deaths per 1,000 live births, a 6.5 percent increase in the infant mortality rate. ${ }^{33}$

The estimated effects in Table 3 are similar in magnitude to the results from the event study. Rescaling the 'event-study' estimates by the average amount of coal-fired capacity post-opening, we calculate that a 100 megawatt increase in coal capacity is associated with a 0.24 increase in infant mortality rate; an effect that compares similarly to the 0.188 average effect reported in Table 3. ${ }^{34}$ The similarity across the two different estimation strategies, each based on different sources of variation, provides additional confidence in the finding.

Table 3, Panels B and C, show substantial heterogeneity in the health effects according to baseline electricity infrastructure. The broad patterns support the 'event-study' results. In counties with high baseline electricity access, increases in coal-fired capacity are associated with higher infant mortality rates. In low access counties, where there was greater scope for expansions in electricity generation to benefit health, the point estimates are small and generally negative. These patterns are consistent with the converging overall trends in infant

\footnotetext{
${ }^{32}$ Consistent with the historical narrative of the power industry, coal-fired capacity expansions were concentrated in counties that were more urban, had larger manufacturing sectors, and higher wages and property values. Nevertheless, given the extended lifespan of these facilities, infrastructure investment decisions were largely unresponsive to contemporaneous trends in economic outcomes, consistent with the negligible Rsquared values reported in columns 3 and 4.

${ }^{33}$ The first result was found by multiplying the estimated coefficient by the standard deviation of coal capacity $(1.98=0.188 \times 10.55)$. The second result was found by dividing the 1.98 by the average infant mortality rate in our coal capacity sample $(6.5=1.98 / 30.4)$.

${ }^{34}$ This result was found by dividing the estimated coefficient by the average increase in coal capacity after the power plant openings in our 'event-study' sample $(0.24=0.609 / 2.55)$.
} 
mortality in Figure A.7.

Appendix Table A.7 shows the results in Table 3 are robust to a range of alternate specifications. The effects are similar in column 1 when all counties within 150 miles of a power plant at the end of our sample period are included in the analysis, and in column 2 when we restrict the sample to counties within 30 miles of a power plant. Notably, the latter set of results are based solely on within-county variation in the timing of capacity expansions, since all counties belong to the 'treatment' sample. Columns 3 and 4 show that the effects are similar, albeit smaller in magnitude, under alternate 50-mile and 100-mile treatment radii, consistent with the localized dispersion of pollutants around power plants. We also find qualitatively similar results in column 5 when the dependent variable is the logarithm of infant mortality. Finally, the last two columns report the results from regressions based on local hydroelectric capacity. Hydro capacity, which produced emissions-free electricity, is associated with net decreases in infant mortality. ${ }^{35}$

Next, we explore whether the net health impacts of coal-fired capacity evolved over the sample period. This period witnessed several important changes - massive increases in electricity infrastructure and the development of high voltage transmission - that may have altered the marginal health benefits from additional expansions in electricity infrastructure. Table 4, Panel A, reports the results from regressions that allow the effect of coal capacity to differ across the pre- and post-1950 periods, roughly the mid-point in sample period. The results show a striking reversal in the coal capacity-infant mortality relationship: in the first half of the sample period, coal-fired generation was associated with decreases in infant mortality; in the latter half of the sample period, coal-fired generation was associated with increases in infant mortality. ${ }^{36}$

To shed light on this reversal, Panel B allows the evolving effects of coal capacity to vary according to baseline generating capacity. The pre-1950 point estimates for coal capacity

\footnotetext{
${ }^{35}$ Given the limited number of hydroelectric power plant openings, there is not enough variation for us to estimate the results separately by baseline electricity access in Panels B and C.

${ }^{36}$ These dynamics run counter to a mechanism in which plant openings initially benefit industry and only later provide health benefits through household electricity access.
} 
are negative for both low-access and high-access counties. The magnitude and significance of the effects is larger in low-access counties, consistent with the increased ability to expand access in these areas relative to high-access counties. In high access counties, the coal capacity-infant mortality relationship becomes positive and statistically significant in the post-1950 period. In low access counties, the relationship remains negative but is statistically insignificant, and resembles the pre-1950 relationship in high-access counties. These results are consistent with the tradeoffs depicted in Figure 3: As the marginal benefits of additional capacity diminished, they were overwhelmed by the (constant) marginal health damage from power plant emissions. ${ }^{37}$ This shift appears to have occurred in both high and low access counties, albeit at different points along the cost-benefit curve.

The results in Table 4, Panels A and B, point to a broad decrease in net benefits from additional coal-fired capacity in the latter half of the sample period. ${ }^{38}$ This shift could reflect national-level changes, such as the expansion in high voltage transmission in the 1950s, that reduced the reliance on local generating infrastructure (Brown and Sedano, 2004). Alternatively, it could reflect a decline in the marginal benefits from capacity additions as the stock of local electricity infrastructure increased. ${ }^{39}$

To separate the role of national-level changes from evolution in the local benefits, we estimate within-county models that allow the effects of coal capacity expansions to differ based on whether they occurred in areas with or without previously established generating infrastructure. We re-estimate equation (2), allowing the effects of coal capacity to differ according to whether they occurred in a location in which a power plant had previously operated for at least ten years or not. Intuitively, these models capture the fact that marginal

\footnotetext{
${ }^{37}$ In fact, research on the relationship between ambient air pollution and mortality indicate that the concentration-response function is concave, so that the health damage from a marginal increase in power plant emissions was more severe pre-1950 (Goodkind, Coggins and Marshall, 2014; Pope III et al., 2015). We have explored the functional form of the dose response curve in the context of power plant-related air pollution and find that it is roughly linear over the range of pollution levels in the sample.

${ }^{38} \mathrm{It}$ is unlikely that the shift was related to changes in health costs from power plant emissions. In fact, to the extent that newly built plants were more efficient, we would expect the coal capacity-infant mortality relationship to become more negative in the post-1950 period, exactly the opposite of these findings.

${ }^{39}$ By 1950, 94 percent of American homes were electrified (Lebergott, 1976, p.279), and industrial access was universal.
} 
benefits from new capacity expansions may depend on whether they occurred in areas that already had an established stock of generating capacity.

Panel C shows that within the first ten years of power plant operations, coal capacity is associated with significant decreases in infant mortality, consistent with higher marginal benefits at lower levels of access. ${ }^{40}$ After ten years, additional expansions in coal capacity led to significant increases in infant mortality. Notably, these findings are unaffected by controls for changes in the coal capacity-infant mortality relationship before and after 1950 . Taken together these results suggest that the shift in the coal capacity-infant mortality relationship in the latter half of the sample period was primarily driven by local evolution in net benefits: as access to electricity infrastructure became widespread, the marginal benefits from subsequent additions diminished.

\subsection{Coal-fired Capacity, Household Technology, and Infant Health}

The previous results show that the health effects of coal-fired generation varied widely, both across counties and over time. Since efforts at pollution abatement were largely absent during this time period, this variation can largely be attributed to differences in the benefits associated with local coal-fired generation. In this section, we explore the extent to which electricity access and its effects on household technology can account for these heterogeneous benefits.

In Table 5, cols. 1-3, we estimate the effects of coal capacity on the percent of homes with various modern technologies. We find that in counties with low baseline electricity access, coal capacity expansions are associated with increases in household electrification, the fraction homes with running water, and the fraction of homes with a modern stove. In contrast, we find no significant effects on technology adoption in counties with high baseline electricity access. These patterns are consistent with expansions in coal-fired generation having benefited infant health through changes in household technology. In particular, the

\footnotetext{
${ }^{40}$ These effects are derived from variation in capacity due both to the initial plant opening and any subsequent expansions in capacity within the first ten years of operation.
} 
previous literature has emphasized the importance of improved sanitation through access to pumped water and other modern appliances, as well as decreases in household air pollution through the elimination of dirty cooking technologies and kerosene lighting.

To further explore the role of improved household hygiene, we evaluate how the relationship between coal-fired capacity and infant mortality varied according to baseline sanitation conditions. Using state-level data on mortality by cause, we calculate the fraction of infant deaths due to diarrhea and enteritis in $1930 .{ }^{41}$ These deaths are primary attributable to environmental factors, such as poor sanitation, poor hygiene, and unsafe drinking water (WHO, 2009, p.9). We use this measure to construct indicators for above- and below-median baseline hygiene-related mortality, and interact the main effects of coal capacity with these measures. ${ }^{42}$ Table 5 col. 4 shows that in low access counties, there were large differences in the effects of coal capacity according to baseline hygiene conditions. In counties with belowmedian hygiene mortality, the net effect on mortality is positive and statistically significant. In contrast, the infant mortality effects are significantly smaller in counties that had abovemedian baseline hygiene mortality, where there was greater scope for modern technologies to improve health.

We also find evidence of improved infant health through reductions in household air pollution, as coal stoves were replaced by modern stoves. Table 5 col. 5 shows that the effects on infant mortality are significantly more negative in counties that were initially more reliant on coal for cooking, where there was more scope to improve household air quality. Among counties with low access to electricity that were also heavily reliant on coal for cooking, increases in coal-fired generating capacity led to reductions in infant mortality, despite having contributed to local air pollution through power plant emissions. Although the amount of coal burned for home cooking was substantially less than for electricity generation,

\footnotetext{
${ }^{41}$ We compiled data on infant mortality by cause from USBC (1930). County by cause data for infant deaths are not currently available in digital form.

${ }^{42} \mathrm{By}$ focusing on the fraction of infant deaths due to diarrhea-enteritis rather than the overall infant diarrhea-enteritis mortality rate, this analysis relies on heterogeneity based on cause-of-death given a particular mortality rate, rather than differences across counties in the baseline infant mortality rate.
} 
the concentration of these emissions in residential neighborhoods increased exposure by a factor of ten (Smith, 1993; Evans et al., 2002).

\subsection{Coal-fired Capacity, Property Values, and Economic Activity}

Expansions in coal-fired generation may have influenced health indirectly through improvements in local economic conditions or changes in demographic composition. In this section, we explore the role of these non-household channels for infant mortality, and explore the extent to which the local tradeoffs were capitalized into property values (Chay and Greenstone, 2005; Mendelsohn and Olmstead, 2009).

Table 6 reports the estimated effects of coal-fired capacity on various outcomes, estimated separately by baseline access and by baseline capacity. All results are estimated for decadal years 1940, 1950, and 1960. ${ }^{43}$ For reference, column 1 reports the estimates for infant mortality based on the decennial sample. Column 2 shows that the effects in the housing market mirror those found for infant mortality. At low levels of access, coal-fired generation has positive effects on rental values. At high levels of baseline access, the effects are negative. Similarly, Panel C shows that initial expansions in coal-fired capacity led to increases in property values, while subsequent expansions led to decreases. ${ }^{44}$ Together, these findings suggest that local residents traded off the benefits of local generation against power plant emissions.

We find some evidence of residential sorting consistent with the housing market response (Banzhaf and Walsh, 2008; Davis, 2011). In columns 7 and 8, in low-access counties, coal capacity expansions are associated with modest increases in the percent of white residents and the percent with a high school diploma, while in high-access counties the effects are insignificant. These demographic changes are too small to explain the heterogeneous patterns

\footnotetext{
${ }^{43}$ All regressions are weighted by the number of live births to match the infant mortality analysis. Qualitatively similar results are found in unweighted regressions.

${ }^{44} \mathrm{We}$ focus on rental values because they reflect contemporaneous conditions, whereas housing values also capture the anticipated future discounted flow of benefits and costs (Banzhaf and Farooque, 2013). Qualitatively similar results are found based on dwelling values.
} 
of mortality reported in Table 3. Combining the estimated changes in racial and educational composition with underlying group differences in mortality, we calculate that just 9 to 19 percent of the observed heterogeneity in mortality can be attributed to sorting. ${ }^{45,46}$

Columns 3 and 4 show that coal capacity expansions stimulated employment growth in both low- and high-access counties. The effects on manufacturing employment were particularly low-access counties, consistent with electricity infrastructure fostering industrial activity in underdeveloped regions (Kline and Moretti, 2014). In contrast, in columns 5 and 6 , we find no evidence that coal capacity expansions increased local wages. The effects are small and statistically insignificant in low access counties, and negative in counties with high access. These patterns are in line with Hanlon (2020), who finds that air pollution during the Industrial Revolution had negative effects on worker productivity. ${ }^{47}$ Taken together, these results indicate that local economic development in low-access areas may also have contributed to improvements in infant health, in addition to the household channel.

\section{$6 \quad$ AP3 model and counterfactuals}

Our results demonstrate that there were important health tradeoffs associated with coalfired electricity generation in mid-twentieth century United States. In this section, we combine plant-level data on annual coal consumption with the AP3 air pollution model to better

\footnotetext{
${ }^{45}$ Changes in the racial composition account for 7 to 17 percent of the mortality gap, while sorting by education account for just 2 percent, consistent with the wide disparities in white/non-white infant mortality during this time period, gaps that dominated other socioeconomic indicator (Collins and Thomasson, 2005). To the extent that racial differences in mortality are partly attributable to educational differences, the sum of the two effects will overstate their combined influence.

${ }^{46}$ These estimates are derived by comparing the differential estimates in Table 3 (col. 3) to the differential estimates in Table 6 (col. 7 and 8) combined with overall differentials in infant mortality in 1950 by race and education. For example, the differential impact of coal capacity on the percent white is $-0.19=$ $(-0.051-0.139)$. Combined with a white versus non-white infant mortality rate differential of -17.7 in 1950 , the implied mortality difference is $0.034=(17.7 \times 0.0019)$, which accounts for $17 \%=0.034 /(0.195-0.001)$ of the mortality differential. Following Collins and Thomasson (2005), and assuming that the individuals with a high school diploma obtained four more years of education than those without it, we calculate a mortality differential of 4.7 across individuals with and without a high school diploma. Together with the estimates in Table 6 (col. 8), we calculate that $2 \%=(-0.014-0.099) / 100 \times 4.7 /(0.195-0.001)$ of the mortality gap can be attributed to sorting by education.

${ }^{47}$ Evidence on the impact of air pollution on labor productivity in recent years is provided by Graff Zivin and Neidell (2012), Chang et al. (2016), Chang et al. (forthcoming), and He, Liu and Salvo (forthcoming).
} 
understand the sources of these local tradeoffs. We apply these estimates to evaluate three counterfactual policies aimed at reducing local air pollution: 1) the replacement of coal-fired generation with nearby hydroelectric power, 2) the construction of tall smokestacks, and 3) the installation of baghouses, an abatement technology. We focus on these three counterfactuals, because the technology was available throughout our sample period. ${ }^{48}$ For additional details on the AP3 model and the counterfactuals, see Appendix B.3.

To measure local air pollution arising from power plant emissions, we use the AP3 pollution model, which links emissions in any source county to the ambient concentration in all destination counties (Muller and Mendelsohn, 2007, 2009). ${ }^{49}$ In this context, the model is used to link power plant sulfur dioxide emissions with destination air pollution. ${ }^{50}$ Annual power plant sulfur dioxide emissions are computed based on total coal consumption and the type of coal being burned, adjusted by the emissions factor for coal-fired power plants in the 1960s (Smith and Gruber, 1966). Plant-level emissions along with information on power plant smokestack heights are inputs into the AP3 model. The model then produces estimates of coal-fired power plants' contribution to ambient air pollution concentrations in origin and destination counties. In Appendix B.3, we show that the AP3 model-based estimates of pollution concentrations, which are derived based on modern environmental conditions, align closely with historical measures of pollution.

To assess the local health tradeoffs associated with coal-fired power plants, we estimate a generalized version of equation (1), in which we include both the main effect of plant openings and its interaction with our continuous AP3 measure of pollution. We redefine the variable 'Near' as an indicator for counties within 60-miles radius of a power plant

\footnotetext{
${ }^{48}$ The use of scrubbers at coal fired power plants occurred after our sample period (Biondo and Marten, 1977).

${ }^{49}$ The AP3 model has been widely used by researchers in economics and environmental sciences (Michalek et al., 2011; Fowlie, Knittel and Wolfram, 2012; Sandler, 2012; Holland et al., 2016; Sanders and Barreca, 2021)

${ }^{50}$ Sulfur dioxide emissions are a marker for the pollution produced by coal-fired power plants. In 1970, 57 percent of U.S. S02 emissions were produced by fossil fuel power plants. Gaseous S02 emissions are transformed into atmospheric sulfates - an important component of particulate matter that is particularly harmful to human health.
} 
to account for potential benefits of local electrification that may have extended up to a distance of 60 miles (Lewis, 2018). In this specification, the main effect, 'Near $\times$ Post Plant Opening', captures the effect of a plant opening when county pollution concentrations are zero. Meanwhile, the interaction term, 'Near $\times$ Post Plant Opening $\times$ Local Pollution', identifies how this effect varies as exposure to plant-related air pollution increases. Thus, the two terms capture the health benefits of electrification and the health costs of power plant emissions. Notably, separate identification of these two effects stems from the complex geoclimatic and atmospheric processes embedded in the AP3 model that determine how ambient air pollution is dispersed after a plant opens.

Figure 7 plots the sum of main effect and interaction effect by the county's percentile plant-related air pollution concentrations. ${ }^{51}$ At the median, the health benefits from electrification and the health costs from plant emissions roughly offset. For counties with air pollution concentrations below the 20th percentile, the net effect of plant openings on infant mortality is negative and statistically significant, suggesting that the health benefits from increased electricity generation outweighed the pollution costs. For counties above the 80th percentile in air pollution, the net effect on infant mortality is positive and statistically significant, suggesting that the health costs from increased air pollution outweighed any benefits from electrification. Interestingly, although the relationship is roughly linear across lower percentiles of air pollution, the health costs rise substantially in the top quartile. ${ }^{52}$ Thus, the overall net negative health effect of plant openings on health appears to stem from the particularly elevated rates of infant mortality in the most heavily polluted counties.

We apply these estimates to assess three counterfactual policies aimed at reducing local air pollution. The first counterfactual considers the displacement of coal-fired electricity generation to nearby hydroelectric sites that were subsequently developed after the end of sample period, from 1962 to 1990. The primary costs associated with this policy were

\footnotetext{
${ }^{51}$ Figure 7 is based on estimates in Panel A of Table 7.

${ }^{52}$ Further analysis reveals that this nonlinearity is a result of particularly elevated air concentrations, which rise exponentially in the top quartile.
} 
increased transmission costs, since electricity would need to be shipped from distant hydroelectric resources. Next, we consider a counterfactual policy mandating the installation of smokestacks that were at least 200 meters in height. The 200-meter height is more than double the average height in the period of our analysis, but the technology to build them had already been developed by the late 1940s (see Appendix Figure A.2). The third counterfactual considers the installation of baghouses, an abatement technology that reduced point source emissions from coal-fired power plant. Although experimentation with scrubbing did not begin until the mid-1960s, fabric filtration systems - known as 'baghouses' - were in use by mid-century and were effective at removing substantial amounts of particulate matter (Silverman, 1950).

Panel B in Table 7 shows that all three counterfactuals achieve substantial sulfate reductions, save large numbers of infant lives per year, and do so at a cost per infant life saved

that is less than the $\$ 1$ million (1990 USD) value of statistical life estimates for the period (Costa and Kahn, 2004). Baghouses would be the most cost effective of the three choices at $\$ 170,000$ per infant life saved. It is important to emphasize that this analysis only focuses on infants and the costs to power plants. Health benefits through decreased morbidity and mortality to other parts of the population, including the elderly and other individuals sensitive to pollution, are not included. Non-health benefits and costs beyond the costs to power plants are also not included. Including these benefits and costs would likely lower the cost per life saved.

\section{Conclusion}

Economic development is often powered by polluting industries. While it is imperative to understand how the health externalities should be weighed against the benefits of the polluting activity along the process of development, empirical evidence on the subject is scarce. This paper represents a first step toward understanding these issues, focusing on 
the local health tradeoffs associated with coal-fired power plants in mid-twentieth century America, large scale investment projects that stimulated local development and produced massive amounts of pollution. We combine a research design that leverages new power plant openings and upgrades at existing facilities with a newly digitized dataset on all major coal-fired power plants.

Expansions in coal-fired generating capacity are estimated to have imposed substantial health costs through local emissions, but also brought significant benefits through increased local electricity infrastructure. The health benefits appear to have arisen primarily through household access to a range of new technologies that improved hygiene and reduced sources of indoor air pollution. Although coal-fired generation initially improved infant health, as the stock of local generating capacity expanded the marginal benefits from subsequent installations diminished, and by the 1950s the pollution costs outweighed the benefits of increased electricity access. Despite the negative impact on health, it took several decades for restrictions on power plant emissions to emerge, with thousands of infant lives lost in the interim.

Our counterfactuals suggest that by mid-20th century, there were cost-effective policies that could have mitigated the health hazards of unregulated plant emissions while maintaining the benefits associated with local electricity infrastructure. The U.S. experience highlights how environmental regulation can be slow to respond to these evolving tradeoffs. Given the longevity of power plants, and the high costs of retrofitting abatement technology, our findings highlight how current decisions over energy mix can have long-lasting health effects.

This paper raises broader questions about the role of air pollution in the process of economic development. As developing countries such as China and India industrialize, with corresponding effects on both income levels and air quality, these challenges become ever more urgent. Since the period of our study, there have been major advances in point source emissions control systems, high voltage transmission, and renewables. These developments 
provide greater scope for regulators to enact policies that foster the economic benefits of local generation while limiting the associated harms to human health. Understanding how best to implement environmental policies that limit emissions without unduly inhibiting development is a critical area for future research. 


\section{References}

Allcott, Hunt, Allan Collard-Wexler, and Stephen D O'Connell. 2016. "How do electricity shortages affect industry? Evidence from India." The American Economic Review, 106(3): 587-624.

Almond, Douglas, Yuyu Chen, Michael Greenstone, and Hongbin Li. 2009. "Winter Heating or Clean Air? Unintended Impacts of China's Huai River Policy?" American Economic Review, 99(2): 184-90.

Arceo, Eva, Rema Hanna, and Paulina Oliva. 2016. "Does the effect of pollution on infant mortality differ between developing and developed countries? Evidence from Mexico City." The Economic Journal, 126(591): 257-280.

Atack, Jeremy. 2016. "Historical Geographic Information Systems (GIS) Database of U.S. Railroads for 1911." Available at https://my.vanderbilt.edu/jeremyatack/datadownloads/.

Atack, Jeremy, Fred Bateman, Michael Haines, and Robert A. Margo. 2010. "Did Railroads Induce or Follow Economic Growth? Urbanization and Population Growth in the American Midwest, 1850-1860." Social Science History, 34(2): 171-197.

Bailey, Martha, Karen Clay, Price Fishback, Michael Haines, Shawn Kantor, Edson Severnini, Anna Wentz, and Inter-university Consortium for Political \& Social Research ICPSR. 2016. "U.S. County-Level Natality and Mortality Data, 1915-2007." Ann Arbor, MI:Inter-university Consortium for Political and Social Research.

Banzhaf, H. Spencer, and Omar Farooque. 2013. "Interjurisdictional Housing Prices and Spatial Amenities: Which Measures of Housing Prices Reflect Local Public Goods?" Regional Science and Urban Economics, 43(4): 635-648.

Banzhaf, H. Spencer, and Randall P. Walsh. 2008. "Do People Vote with Their Feet? An Empirical Test of Tiebout." American Economic Review, 98(3): 843-863.

Barreca, Alan, Karen Clay, and Joel Tarr. 2014. "Coal, Smoke, and Death: Bituminous Coal and American Home Heating." NBER Working Paper \#19881.

Barron, Manuel, and Maximo Torero. 2017. "Household Electrification and Indoor Air Pollution." Journal of Environmental Economics and Management, 86: 81-92.

Baum-Snow, Nathaniel. 2007. "Did Highways Cause Suburbanization?" Quarterly Journal of Economics, 122(2): 775-805.

Biondo, S. J., and J. C. Marten. 1977. "A History of Flue Gas Desulphurization Systems Since 1850." Journal of the Air Pollution Control Association, 27(10): 948-961.

Brown, Matthew H., and Richard P. Sedano. 2004. Electricity Transmission: A Primer. Denver, CO:National Council on Electricity Policy (NCEL). 
Cavender, James H, David S Kircher, and Alan J Hoffman. 1973. Nationwide Air Pollutant Emission Trends, 1940-1970. US Environmental Protection Agency, Office of Air Quality Planning and .

Cengiz, Doruk, Arindrajit Dube, Attila Lindner, and Ben Zipperer. 2019. "The Effect of Minimum Wages on Low-Wage Jobs." Quarterly Journal of Economics, 134(3): 1405-1454.

Chang, Tom Y., Joshua Graff Zivin, Tal Gross, and Matthew Neidell. 2016. "Particulate Pollution and the Productivity of Pear Packers." American Economic Journal: Economic Policy, 8(3): 141-69.

Chang, Tom Y., Joshua Graff Zivin, Tal Gross, and Matthew Neidell. forthcoming. "The Effect of Pollution on Worker Productivity: Evidence from Call Center Workers in China." American Economic Journal: Applied Economics.

Chay, Kenneth Y., and Michael Greenstone. 2003a. "The Impact of Air Pollution on Infant Mortality: Evidence from Geographic Variation in Pollution Shocks Induced by a Recession." Quarterly Journal of Economics, 118(3): 1121-1167.

Chay, Kenneth Y., and Michael Greenstone. 2003b. "Air Quality, Infant Mortality, and the Clean Air Act of 1970." NBER Working Paper \#10053.

Chay, Kenneth Y., and Michael Greenstone. 2005. "Does Air Quality Matter? Evidence from the Housing Market." Journal of Political Economy, 113(2): 376-424.

Chen, Yuyu, Avraham Ebenstein, Michael Greenstone, and Hongbin Li. 2013. "Evidence on the impact of sustained exposure to air pollution on life expectancy from Chinas Huai River policy." Proceedings of the National Academy of Sciences of the United States of America (PNAS), 110(32): 12936-12941.

Cirillo, R.R., T.D. Wolsko, R.O. Mueller, P.A. Dauzvardis, M.J. Senew, K. Camauf, and D.A. Seymour. 1977. "An Evaluation of Regional Trends in Power Plant Siting and Energy Transport." Argonne National Laboratory, Energy and Environmental Systems Division. Available at osti.gov/servlets/purl/6654924.

Cohen, Aaron J., H. Ross Anderson, Bart Ostro, Kiran Dev Pandey, Michal Krzyzanowski, Nino Knzli, Kersten Gutschmidt, C. Arden Pope III, Isabelle Romieu, Jonathan M. Samet, and Kirk R. Smith. 2004. "Urban Air Pollution." In Comparative Quantification of Health Risks: Global and Regional Burden of Disease Attributable to Selected Major Risk Factors, ed. Majid Ezzati, Alan D. Lopez, Anthony Rodgers and Christopher J.L. Murray, Vol. 2. Geneva:World Health Organization.

Collins, William J., and Melissa A. Thomasson. 2005. "The Declining Contribution of Socioeconomic Disparities to the Racial Gap in Infant Mortality Rates, 1920-1970." Southern Economic Journal, 70(4): 746-776.

Costa, Dora L., and Matthew E. Kahn. 2004. "Changes in the Value of Life, 1940-1980." Journal of Risk and Uncertainty, 29(2): 159-180. 
Currie, Janet, and Matthew Neidell. 2005. "Air Pollution and Infant Health: What Can We Learn From California's Recent Experience?" Quarterly Journal of Economics, 120(3): 1003-1030.

Currie, Janet, and W. Reed Walker. 2011. "Traffic Congestion and Infant Health: Evidence from E-ZPass." American Economic Journal: Applied Economics, 3(1): 65-90.

Currie, Janet, Joshua Graff Zivin, Jamie Mullins, and Matthew Neidell. 2014. "What Do We Know About Short- and Long-Term Effects of Early-Life Exposure to Pollution?" Annual Review of Resource Economics, 6(1): 217-247.

Davis, Lucas W. 2011. "The Effect of Power Plants on Local Housing Values and Rents." Review of Economics and Statistics, 93(4): 1391-1402.

Deryugina, Tatyana, Garth Heutel, Nolan H Miller, David Molitor, and Julian Reif. 2016. "The Effect of Pollution on Health and Health Care Utilization: Evidence from Changes in Wind Direction."

Dinkelman, Taryn. 2011. "The Effects of Rural Electrification on Employment: New Evidence from South Africa." American Economic Review, 101(7): 3078-3108.

Donaldson, Dave. 2018. "Railroads of the Raj: Estimating the Impact of Transportation Infrastructure." American Economic Review, 108(4-5): 899-934.

Donaldson, Dave, and Richard Hornbeck. 2016. "Railroads and American Economic Growth: A "Market Access" Approach." Quarterly Journal of Economics, 131(2): 799858.

DuBay, Shane G, and Carl C Fuldner. 2017. "Bird specimens track 135 years of atmospheric black carbon and environmental policy." Proceedings of the National Academy of Sciences, 114(43): 11321-11326.

Duflo, Esther, and Rohini Pande. 2007. "Dams." Quarterly Journal of Economics, 122(2): 601-646.

Ebenstein, Avraham, Maoyong Fan, Michael Greenstone, Guojun He, and Maigeng Zhou. 2017. "New evidence on the impact of sustained exposure to air pollution on life expectancy from Chinas Huai River Policy." Proceedings of the National Academy of Sciences of the United States of America (PNAS), 114(39): 10384-10389.

EPA, U.S. Environmental Protection Agency. 2011. "Final Response to Petition From New Jersey Regarding SO2 Emissions From the Portland Generating Station; Final Rule." Federal Register, 76(215): 69051-69077.

Evans, John S., Scott K. Wolff, Kanchanasak Phonboon, Jonathan I. Levy, and Kirk R. Smith. 2002. "Exposure Efficiency: An Idea Whose Time Has Come?" Chemosphere, 49: 1075-1091. 
Faber, Benjamin. 2014. "Trade Integration, Market Size, and Industrialization: Evidence from China's National Trunk Highway System." Review of Economic Studies, 81(3): 10461070 .

Fishback, Price, and Carl Kitchens. 2015. "Flip the Switch: The Impact of the Rural Electrification Administration 1935-1940." Journal of Economic History, 74(4): 11611195.

Fishback, Price, Michael Haines, Shawn Kantor, and Joseph Cullen. n.d.. "County and City Mortality Data, 1921 to 1950." Available at econ.arizona.edu/faculty/fishback.asp.

Fowlie, Meredith, Christopher R Knittel, and Catherine Wolfram. 2012. "Sacred cars? Cost-effective regulation of stationary and nonstationary pollution sources." American Economic Journal: Economic Policy, 4(1): 98-126.

FPC, U.S. Federal Power Commission. 1947. "Steam-Electric Plant Construction Cost and Annual Production Expenses, 1938-1947." Washington, DC:U.S. Federal Power Commission.

FPC, U.S. Federal Power Commission. 1948-62. "Steam-Electric Plant Construction Cost and Annual Production Expenses (Annual Supplements)." Washington, DC:U.S. Federal Power Commission.

FPC, U.S. Federal Power Commission. 1963. "Principal Electric Power Facilities in the United States (Map)." Washington, DC:U.S. Federal Power Commission.

FPC, US Federal Power Commission. 1964. The National Power Survey, pt. 1. Washington, DC: Government Printing Office.

Gartner, Scott Sigmund, et al. 2006. In Historical Statistics of the United States, ed. Susan B. Carter, Scott Sigmund Gartner, Michael R. Haines, Alan L. Olmstead, Richard Sutch and Gavin Wright. New York, NY:Cambridge University Press.

Goodkind, Andrew L., Jay S. Coggins, and Julian D. Marshall. 2014. "A Spatial Model of Air Pollution: The Impact of the Concentration-Response Function." Journal of the Association of Environmental and Resource Economists, 1(4): 451-479.

Goodman-Bacon, Andrew. 2021. "Difference-in-differences with variation in treatment timing." Journal of Econometrics.

Graff Zivin, Joshua, and Matthew Neidell. 2012. "The Impact of Pollution on Worker Productivity." American Economic Review, 102(7): 3652-3673.

Greenstone, Michael, and B. Kelsey Jack. 2015. "Envirodevonomics: A Research Agenda for an Emerging Field." Journal of Economic Literature, 53(1): 5-42.

Greenstone, Michael, Richard Hornbeck, and Enrico Moretti. 2010. "Identifying Agglomeration Spillovers: Evidence from Winners and Losers of Large Plant Openings." Journal of Political Economy, 118(3): 536-598. 
Haines, Michael, and Robert A. Margo. 2008. "Railroads and Local Economic Development: The United States in the 1850s." In Quantitative Economic History: The Good of Counting, ed. Joshua L. Rosenbloom, pp. 78-99. London, UK:Routledge.

Haines, Michael R., and Inter-university Consortium for Political \& Social Research ICPSR. 2010. Historical, Demographic, Economic, and Social Data: The United States, 1790-2002. Ann Arbor, MI:Inter-university Consortium for Political and Social Research, icpsr.org.

Hales, Jeremy M. 1976. "Tall Stacks and the Atmospheric Environment." EPA Publication, No. EPA-450/3-76-007.

Hanlon, W Walker. 2020. "Coal smoke, city growth, and the costs of the industrial revolution." The Economic Journal, 130(626): 462-488.

Hanna, Rema, Esther Duflo, and Michael Greenstone. 2016. "Up in Smoke: The Influence of Household Behavior on the Long-Run Impact of Improved Cooking Stoves." American Economic Journal: Economic Policy, 8(1): 80-114.

He, Jiaxiu, Haoming Liu, and Alberto Salvo. forthcoming. "Severe Air Pollution and Labor Productivity: Evidence from Industrial Towns in China." American Economic Journal: Applied Economics.

Holland, Stephen P, Erin T Mansur, Nicholas Z Muller, and Andrew J Yates. 2016. "Are there environmental benefits from driving electric vehicles? The importance of local factors." American Economic Review, 106(12): 3700-3729.

Hoynes, Hilary, Doug Miller, and David Simon. 2015. "Income, the Earned Income Tax Credit, and Infant Health." American Economic Journal: Economic Policy, 7(1): 172211.

Hughes, Thomas. 1993. Networks of Power: Electrification in Western Society, 18801930. Baltimore, MD:Johns Hopkins University Press.

Ives, James Edmund, Rollo H. Britten, David William Armstrong, Wirt Alvin Gill, and Frederick Herbert Goldman. 1936. "Atmospheric Pollution of American Cities for the Years 1931 to 1933 with Special Reference to the Solid Constituents of the Pollution." U.S. Treasury Department, Public Health Bulletin No 224, Washington, DC:Government Printing Office.

Kline, Patrick. 2012. "The Impact of Juvenile Curfew Laws on Arrests of Youth and Adults." American Law and Economics Review, 14(1): 44-67.

Kline, Patrick, and Enrico Moretti. 2014. "Local Economic Development, Agglomeration Economies, and the Big Push: 100 Years of Evidence from the Tennessee Valley Authority." Quarterly Journal of Economics, 129(1): 275-331. 
Lam, Nicholas L., Kirk R. Smith, Alison Gauthier, and Michael N. Bates. 2012. "Kerosene: A Review of Household Uses and Their Hazards in Low- and Middle-income Countries." Journal of Toxicology and Environmental Health - Part B: Critical Reviews, 15(6): 396-432.

Lave, Lester, and Eugene Seskin. 1972. "Air Pollution, Climate, and Home Heating: Their Effects on U.S. Mortality Rates." American Journal of Public Health, 62: 909-916.

Lebergott, Stanley. 1976. The American Economy: Income, Wealth and Want. Princeton, NJ:Princeton University Press.

Levy, Jonathan I., John D. Spengler, Dennis Hlinka, David Sullivan, and Dennis Moon. 2002. "Using CALPUFF to Evaluate the Impacts of Power Plant Emissions in Illinois: Model Sensitivity and Implications." Atmospheric Environment, 36: 1063-1075.

Lewis, Joshua. 2018. "Infant Health, Women's Fertility, and Rural Electrification in the United States." Journal of Economic History, 78(1): 118-154.

Lewis, Joshua, and Edson Severnini. 2020. "Short-and long-run impacts of rural electrification: evidence from the historical rollout of the US power grid." Journal of Development Economics, 143: 102412.

Lipfert, Frederick W., and Ronald E. Wyzga. 1995. "Air Pollution and Mortality: Issues and Uncertainties." Journal of the Air $\&$ Waste Management Association, 45(12): 949-966.

Lipscomb, Molly, Mushfiq A. Mobarak, and Tania Barham. 2013. "Development Effects of Electrification: Evidence from the Topographic Placement of Hydropower Plants in Brazil." American Economic Journal: Applied Economics, 5(2): 200-231.

Luff, Willard J. 1940. "Water Systems and Bathrooms for Farm Homes." Rural Electrification News, September.

Meckel, Richard A. 1990. Save the Babies: American Public Health Reform and the Prevention of Infant Mortality, 1850-1929. Ann Arbor, MI:University of Michigan Press.

Mendelsohn, Robert, and Sheila Olmstead. 2009. "The Economic Valuation of Environmental Amenities and Disamenities: Methods and Applications." Annual Review of Environment and Resources, 34: 325-347.

Michaels, Guy. 2008. "The Effect of Trade on the Demand for Skill: Evidence from the Interstate Highway System." Review of Economics and Statistics, 90(4): 683-701.

Michalek, Jeremy J, Mikhail Chester, Paulina Jaramillo, Constantine Samaras, Ching-Shin Norman Shiau, and Lester B Lave. 2011. "Valuation of plug-in vehicle life-cycle air emissions and oil displacement benefits." Proceedings of the National Academy of Sciences, 108(40): 16554-16558. 
Mokyr, Joel. 2000. "Why "More Work for Mothers?" Knowledge and Household Behavior, 1870-1945." Journal of Economic History, 60(1): 1-41.

Muller, Nicholas Z, and Robert Mendelsohn. 2007. "Measuring the damages of air pollution in the United States." Journal of Environmental Economics and Management, 54(1): 1-14.

Muller, Nicholas Z, and Robert Mendelsohn. 2009. "Efficient pollution regulation: getting the prices right." American Economic Review, 99(5): 1714-39.

Newman, L. 1980. "Atmospheric oxidation of sulfur dioxide as viewed from power plant and smelter plume studies." Brookhaven National Lab., Upton, NY (USA).

NRC, National Research Council. 1975. Air Quality and Stationary Source Emission Control: A Report. US Government Printing Office.

Oster, Emily. 2019. "Unobservable Selection and Coefficient Stability: Theory and Evidence." Journal of Business $\&$ Economic Statistics, 37(2): 187-204.

Pope III, C. Arden, Maureen Cropper, Jay Coggins, and Aaron Cohen. 2015. "Health Benefits of Air Pollution Abatement Policy: Role of the Shape of the Concentration-Response Function." Journal of the Air $\&$ Waste Management Association, 65(5): 516-522.

Rud, Juan Pablo. 2012. "Electricity and Industrial Development: Evidence from India." Journal of Development Economics, 92(2): 352-367.

Sanders, Nicholas J, and Alan Barreca. 2021. "Adaptation to Environmental Change: Agriculture and the Unexpected Incidence of the Acid Rain Program." Forthcoming, American Economic Journal: Economic Policy.

Sandler, Ryan. 2012. "Clunkers or junkers? Adverse selection in a vehicle retirement program." American Economic Journal: Economic Policy, 4(4): 253-81.

Schlenker, Wolfram, and W. Reed Walker. 2016. "Airports, Air Pollution, and Contemporaneous Health." Review of Economic Studies, 83(2): 768-809.

Severnini, Edson. 2014. "The Power of Hydroelectric Dams: Agglomeration Spillovers." IZA Discussion Paper \#8082.

Silverman, Leslie. 1950. "Filtration Through Porous Materials." American Industrial Hygiene Association Quarterly, 11(1): 11-20.

Smith, Kirk R. 1993. "Fuel Combustion, Air Pollution Exposure, and Health: The Situation in Developing Countries." Annual Review of Energy and the Environment, 18: 529566.

Smith, Walter S, and Charles W Gruber. 1966. Atmospheric emissions from coal combustion: An inventory guide. US Division of Air Pollution. 
Spix, Claudia, Joachim Heinrich, Douglas Dockery, Joel Schwartz, Gisela Volksch, Kurt Schwinkowski, Christel Collen, and H. Erich Wichmann. 1993. "Air Pollution and Daily Mortality in Erfurt, East Germany, 1980-1989." Environmental Health Perspectives, 101(6): 518-526.

Thomas, FW, SB Carpenter, and FE Gartrell. 1963. "Stacks - How High?" Journal of the Air Pollution Control Association, 13(5): 198-204.

Trimble, David C. 2011. "Air Quality: information on tall smokestacks and their contribution to interstate transport of air pollution." United States Government Accountability Office, GAO 11-473.

Turner, JH, JD McKenna, JC Mycock, AB Nunn, and WM Vatavuk. 1998. "Baghouses and filters." In EPA Air Pollution Cost Control Manual: Section 6: Particulate Matter Controls1-59. United States Environmental Protection Agency, Research Triangle Park, USA.

USBC, U.S. Bureau of the Census. 1930. "Mortality Statistics." US Department of Commerce, Bureau of the Census.

USBC, U.S. Bureau of the Census. 1963. "1960 Census of Housing - Volume I, States and Small Areas (Part 1, United States Summary)." US Department of Commerce, Bureau of the Census.

USDOC, U.S. Department of Commerce Bureau of the Census, and Interuniversity Consortium for Political \& Social Research ICPSR. 2012. "County and City Data Book (United States) Consolidated File: County Data, 1947-1977." Ann Arbor, MI:Inter-university Consortium for Political and Social Research, ICPSR07736-v2.

USEIA, US Energy Information Administration. 2011. Annual energy review. Washington, DC: Government Printing Office.

USEIA, U.S. Energy Information Association. 2021. "Levelized Costs of New Generation Resources in the Annual Energy Outlook 2021." US Department of Energy.

USEPA, US Environmental Protection Agency. 2004. "The particle pollution report: Current understanding of air quality and emissions through 2003."

USHEW, U.S. Department of Health, Education \& Welfare. 1952-1958b. "Marriage, Divorce, Natality, Fetal Mortality and Infant Mortality Data." Vital Statistics of the United States (Volume I), Washington, DC:Government Printing Office.

USHEW, U.S. Department of Health, Education \& Welfare. 1958a. "Air Pollution Measurements of the National Air Sampling Network: Analyses of Suspended Particulates, 1953-1957." Public Health Service Publication No. 637, Washington, DC:Government Printing Office. 
USHEW, U.S. Department of Health, Education \& Welfare. 1968. "Tall Stacks, Various Atmospheric Phenomena and Related Aspects: An Annotated Bibliography and Discussion." Public Health Service, Consumer Protection and Environmental Health Service, Washington, DC:Government Printing Office.

USHEW, U.S. Department of Health, Education \& Welfare. 1969. "Control Techniques for Particulate Air Pollution." Public Health Service Protection and Environmental Health Service, Washington, DC:Government Printing Office.

Wilson, Maud. 1929. "Present Use of Time in Households and by Homemakers: Complete Report of Purnell Study." Oregon State Agricultural Experiment Station.

Woodruff, Tracey, Lyndsey Darrow, and Jennifer Parker. 2008. "Air Pollution and Postneonatal Infant Mortality in the United States, 1999-2002." Environmental Health Perspectives, 116(1): 110-115. 


\section{Tables and Figures}

Table 1: The Effect of Coal-fired Power Plant Openings on Infant Mortality, 1938-1962

\begin{tabular}{|c|c|c|c|}
\hline & \multicolumn{3}{|c|}{ Dependent variable: Infant Mortality Rate } \\
\hline & $(1)$ & $(2)$ & $(3)$ \\
\hline \multicolumn{4}{|l|}{ Panel A: Overall effects } \\
\hline 1(Plant Operating $) \times$ Near & $\begin{array}{c}0.877^{* * *} \\
(0.215)\end{array}$ & $\begin{array}{c}0.780^{* * *} \\
(0.215)\end{array}$ & $\begin{array}{c}0.609^{* * *} \\
(0.192)\end{array}$ \\
\hline R-squared & 0.673 & 0.673 & 0.679 \\
\hline \multicolumn{4}{|c|}{ Panel B: Effects by Generating Capacity in 1940: Below vs. Above median } \\
\hline $\begin{array}{l}\text { 1(Plant Operating }) \times \text { Near } \\
\quad \times \text { Below }\end{array}$ & $\begin{array}{r}-0.620^{*} \\
(0.366)\end{array}$ & $\begin{array}{l}-0.540 \\
(0.354)\end{array}$ & $\begin{array}{l}-0.194 \\
(0.319)\end{array}$ \\
\hline $\begin{array}{l}1 \text { (Plant Operating }) \times \text { Near } \\
\quad \times \text { Above }\end{array}$ & $\begin{array}{c}1.303^{* * *} \\
(0.252)\end{array}$ & $\begin{array}{c}1.197^{* * *} \\
(0.266)\end{array}$ & $\begin{array}{c}0.870^{* * *} \\
(0.236)\end{array}$ \\
\hline P-value: Test $\beta_{\text {Below }}=\beta_{\text {Above }}$ & 0.000 & 0.001 & 0.007 \\
\hline R-squared & 0.673 & 0.673 & 0.679 \\
\hline \multicolumn{4}{|c|}{ Panel C: Effects by Household Electricity Access in 1940: Below vs. Above median } \\
\hline $\begin{array}{l}1 \text { (Plant Operating }) \times \text { Near } \\
\quad \times \text { Below }\end{array}$ & $\begin{array}{l}-0.437 \\
(0.325)\end{array}$ & $\begin{array}{l}-0.396 \\
(0.315)\end{array}$ & $\begin{array}{c}0.018 \\
(0.291)\end{array}$ \\
\hline $\begin{array}{l}1 \text { (Plant Operating }) \times \text { Near } \\
\times \text { Above }\end{array}$ & $\begin{array}{c}1.525^{* * *} \\
(0.268)\end{array}$ & $\begin{array}{c}1.419^{* * *} \\
(0.292)\end{array}$ & $\begin{array}{c}0.936^{* * *} \\
(0.265)\end{array}$ \\
\hline P-value: Test $\beta_{\text {Below }}=\beta_{\text {Above }}$ & 0.000 & 0.000 & 0.021 \\
\hline R-squared & 0.673 & 0.673 & 0.679 \\
\hline Observations & 132,000 & 132,000 & 132,000 \\
\hline County-plant pairs & 5,280 & 5,280 & 5,280 \\
\hline Counties & 1,969 & 1,969 & 1,969 \\
\hline County-Plant FE & $\mathrm{Y}$ & $\mathrm{Y}$ & $\mathrm{Y}$ \\
\hline State-by-Year FE & $\mathrm{Y}$ & $\mathrm{Y}$ & $\mathrm{Y}$ \\
\hline Research Design Variables & $\mathrm{Y}$ & $\mathrm{Y}$ & $\mathrm{Y}$ \\
\hline Geographic Variables & $\mathrm{Y}$ & $\mathrm{Y}$ & $\mathrm{Y}$ \\
\hline 1940 Mfg Emp x Year & & $\mathrm{Y}$ & $\mathrm{Y}$ \\
\hline All Other Controls & & & $\mathrm{Y}$ \\
\hline
\end{tabular}

Notes: This table reports the 'event-study' estimates from equation (1). Each column in each panel reports the point estimates from a different regression. The infant mortality rate is per 1,000 live births. Near is an indicator equal to one if the county-centroid distance to the power plant is less than 30 miles, and zero if the county-centroid is from 30 to 90 miles from the plant. 'Research Design Variables' include a time trend based on county-centroid distance to the coal-fired power plant, and annual nameplate capacity of the plant to ensure that identification relies solely on the timing of power plant openings. 'Geographic Variables' include time trends based on county longitude and latitude, annual precipitation, average temperature, degree days below $10^{\circ} \mathrm{C}$ and degree days above $29^{\circ} \mathrm{C}$. 'All Other Controls' include annual hydropower capacity within 30 miles of a county-centroid, and time trends based on a variety of baseline county characteristics - log population, log employment, and proportion of households with electricity access in 1940, mileage of rail tracks in the beginning of the twentieth century (1911), and an indicator for whether a county was recommended to receive a highway from the 1944 Interstate Highway Plan. All regressions are weighted by live births. Standard errors are clustered at the county-level. $* * *, * *, *$ denote significance at the $1 \%, 5 \%$, and $10 \%$ level, respectively. 
Table 2: Predictors of Coal Capacity Changes, 1938-1962

\begin{tabular}{|c|c|c|c|c|}
\hline & \multicolumn{4}{|c|}{ Dependent variable: $\Delta$ Coal Capacity, 1938-1962 } \\
\hline & \multicolumn{4}{|c|}{ Explanatory variables measured in } \\
\hline & \multicolumn{2}{|c|}{ Levels, 1940} & \multicolumn{2}{|c|}{ Changes, 1930-1940 } \\
\hline & $(1)$ & $(2)$ & $(3)$ & $(4)$ \\
\hline Above vs. below median capacity, 1940 & Above & Below & Above & Below \\
\hline \multicolumn{5}{|l|}{ Panel A: Economic variables } \\
\hline Log(total employment) & $\begin{array}{c}2.7652^{* * *} \\
(0.6994)\end{array}$ & $\begin{array}{c}0.3061^{* * *} \\
(0.0997)\end{array}$ & $\begin{array}{c}3.0965 \\
(1.9710)\end{array}$ & $\begin{array}{l}0.5720^{*} \\
(0.2892)\end{array}$ \\
\hline R-squared & 0.153 & 0.0069 & 0.0090 & 0.0019 \\
\hline Manufacturing employment share & $\begin{array}{c}0.0996^{* *} \\
(0.0469)\end{array}$ & $\begin{array}{c}0.0136 \\
(0.0131)\end{array}$ & $\begin{array}{c}0.1054 \\
(0.0729)\end{array}$ & $\begin{array}{c}0.0071 \\
(0.0125)\end{array}$ \\
\hline R-squared & 0.0264 & 0.0020 & 0.0051 & 0.0002 \\
\hline Manufacturing payroll per worker & $\begin{array}{c}0.4318^{* *} \\
(0.1970)\end{array}$ & $\begin{array}{l}-0.0001 \\
(0.0011)\end{array}$ & $\begin{array}{c}0.0664 \\
(0.2295)\end{array}$ & $\begin{array}{l}-0.0004 \\
(0.0010)\end{array}$ \\
\hline R-squared & 0.0306 & 0.0000 & 0.0005 & 0.0000 \\
\hline Retail payroll per worker & $\begin{array}{c}2.5954^{* * *} \\
(0.7333)\end{array}$ & $\begin{array}{c}0.0032 \\
(0.0024)\end{array}$ & $\begin{array}{c}-0.1216 \\
(0.3157)\end{array}$ & $\begin{array}{c}0.0028 \\
(0.0025)\end{array}$ \\
\hline R-squared & 0.1490 & 0.0001 & 0.0002 & 0.0000 \\
\hline Railroad miles, 1911 & $\begin{array}{c}0.0151 \\
(0.0098)\end{array}$ & $\begin{array}{c}0.0007 \\
(0.0021)\end{array}$ & & \\
\hline R-squared & 0.0158 & 0.000190 & & \\
\hline Predicted interstate highway, 1944 & $\begin{array}{c}3.0331^{* * *} \\
(0.8033)\end{array}$ & $\begin{array}{c}0.1947 \\
(0.2020)\end{array}$ & & \\
\hline R-squared & 0.0357 & 0.0012 & & \\
\hline \multicolumn{5}{|l|}{ Panel B: Demographic variables } \\
\hline Infant mortality rate & $\begin{array}{c}-0.0461 \\
(0.0304)\end{array}$ & $\begin{array}{c}-0.0003 \\
(0.0053)\end{array}$ & $\begin{array}{c}-0.0223 \\
(0.0232)\end{array}$ & $\begin{array}{l}-0.0052^{*} \\
(0.0028)\end{array}$ \\
\hline R-squared & 0.0066 & 0.0000 & 0.0024 & 0.0017 \\
\hline Percent urban & $\begin{array}{c}0.0757^{* * * *} \\
(0.0245)\end{array}$ & $\begin{array}{c}0.0077^{* *} \\
(0.0031)\end{array}$ & $\begin{array}{c}0.0643 \\
(0.0543)\end{array}$ & $\begin{array}{c}-0.0174^{* *} \\
(0.0083)\end{array}$ \\
\hline R-squared & 0.0671 & 0.0037 & 0.0025 & 0.0015 \\
\hline Percent white & $\begin{array}{l}-0.0687 \\
(0.0647)\end{array}$ & $\begin{array}{l}-0.0019 \\
(0.0030)\end{array}$ & $\begin{array}{c}0.0660 \\
(0.0543)\end{array}$ & $\begin{array}{c}0.0016 \\
(0.0030)\end{array}$ \\
\hline R-squared & 0.0046 & 0.0001 & 0.0008 & 0.0000 \\
\hline Log(median dwelling rent) & $\begin{array}{c}8.1441^{* * *} \\
(1.9627)\end{array}$ & $\begin{array}{c}0.4132 \\
(0.3698)\end{array}$ & $\begin{array}{c}0.7269 \\
(3.4226)\end{array}$ & $\begin{array}{c}0.5472 \\
(0.4772)\end{array}$ \\
\hline R-squared & 0.1590 & 0.0028 & 0.0002 & 0.0015 \\
\hline
\end{tabular}

Notes: This table reports estimates from the analysis exploring the predictive power of levels and pre-trends of baseline county characteristics in explaining changes in coal-fired electricity generating capacity over the period 1938-1962. Each cell reports the estimates from a single regression of the change in coal capacity from 1938 to 1962 on the indicated county characteristic, conditional on state fixed effects and weighted by live births. Standard errors are clustered at the county-level; $* * *, * *, *$ denote significance at $1 \%, 5 \%$, and $10 \%$, respectively. 
Table 3: The Effect of Coal Capacity on Infant Mortality, 1938-1962

\begin{tabular}{|c|c|c|c|}
\hline & \multicolumn{3}{|c|}{ Dependent variable: Infant Mortality Rate } \\
\hline & $(1)$ & $(2)$ & $(3)$ \\
\hline \multicolumn{4}{|l|}{ Panel A: Overall effects } \\
\hline Coal capacity & $\begin{array}{c}0.213^{* * *} \\
(0.030)\end{array}$ & $\begin{array}{c}0.222^{* * *} \\
(0.025)\end{array}$ & $\begin{array}{c}0.188^{* * *} \\
(0.027)\end{array}$ \\
\hline R-squared & 0.639 & 0.675 & 0.679 \\
\hline \multicolumn{4}{|c|}{ Panel B: Effects by Generating Capacity in 1940: Below vs. Above median } \\
\hline Coal capacity $\times$ Below & $\begin{array}{c}-0.146^{* * *} \\
(0.051)\end{array}$ & $\begin{array}{l}-0.094^{*} \\
(0.049)\end{array}$ & $\begin{array}{l}-0.040 \\
(0.058)\end{array}$ \\
\hline Coal capacity $\times$ Above & $\begin{array}{c}0.215^{* * *} \\
(0.027)\end{array}$ & $\begin{array}{c}0.229^{* * *} \\
(0.025)\end{array}$ & $\begin{array}{c}0.203^{* * *} \\
(0.028)\end{array}$ \\
\hline \multirow{2}{*}{$\begin{array}{l}\text { P-value: Test } \beta_{\text {Below }}=\beta_{\text {Above }} \\
\text { R-squared }\end{array}$} & 0.000 & 0.000 & 0.000 \\
\hline & 0.640 & 0.676 & 0.680 \\
\hline \multicolumn{4}{|c|}{$\begin{array}{l}\text { Panel C: Effects by Household Electricity Access in 1940: Below vs. Above median } \\
\end{array}$} \\
\hline Coal capacity $\times$ Below & $\begin{array}{c}-0.145^{* * *} \\
(0.043)\end{array}$ & $\begin{array}{l}-0.036 \\
(0.041)\end{array}$ & $\begin{array}{c}0.001 \\
(0.043)\end{array}$ \\
\hline Coal capacity $\times$ Above & $\begin{array}{c}0.214^{* * *} \\
(0.026)\end{array}$ & $\begin{array}{c}0.233^{* * *} \\
(0.025)\end{array}$ & $\begin{array}{c}0.195^{* * *} \\
(0.030)\end{array}$ \\
\hline \multirow{2}{*}{$\begin{array}{l}\text { P-value: Test } \beta_{\text {Below }}=\beta_{\text {Above }} \\
\text { R-squared }\end{array}$} & 0.000 & 0.000 & 0.000 \\
\hline & 0.640 & 0.676 & 0.680 \\
\hline \multirow{2}{*}{ Observations } & 50,675 & 50,675 & 50,675 \\
\hline & 2,027 & 2,027 & 2,027 \\
\hline \multirow{3}{*}{$\begin{array}{l}\text { County and Year FE } \\
\text { State-by-Year FE } \\
\text { All controls } \\
\end{array}$} & $\mathrm{Y}$ & $\mathrm{Y}$ & $\mathrm{Y}$ \\
\hline & & $\mathrm{Y}$ & $\mathrm{Y}$ \\
\hline & & & $\mathrm{Y}$ \\
\hline \multicolumn{4}{|c|}{$\begin{array}{l}\text { Notes: This table reports the difference-in-differences estimates from equation (2). Each } \\
\text { column in each panel reports the point estimates from a different regression. The infant } \\
\text { mortality rate is per } 1,000 \text { live births. The variable Coal capacity denotes total coal-fired } \\
\text { capacity within } 30 \text { miles of the county-centroid (measured in } 100 \text { s of megawatts). 'All } \\
\text { Controls' include time trends based on county longitude and latitude, annual precipita- } \\
\text { tion, average temperature, degree days below } 10^{\circ} \mathrm{C} \text { and degree days above } 29^{\circ} \mathrm{C} \text {, annual } \\
\text { hydropower capacity within } 30 \text { miles of a county-centroid, and time trends based on a } \\
\text { variety of baseline county characteristics - log population, log employment, and log man- } \\
\text { ufacturing employment in } 1940 \text {, mileage of rail tracks in the beginning of the twentieth } \\
\text { century (1911), and an indicator for whether a county was recommended to receive a high- } \\
\text { way from the } 1944 \text { Interstate Highway Plan. All regressions are weighted by live births. } \\
\text { Standard errors are clustered at the county-level. ***,**, denote significance at the } 1 \% \text {, } \\
5 \% \text {, and } 10 \% \text { level, respectively. }\end{array}$} \\
\hline
\end{tabular}


Table 4: Evolution in the Coal Capacity-Infant Mortality Relationship, 1938-1962

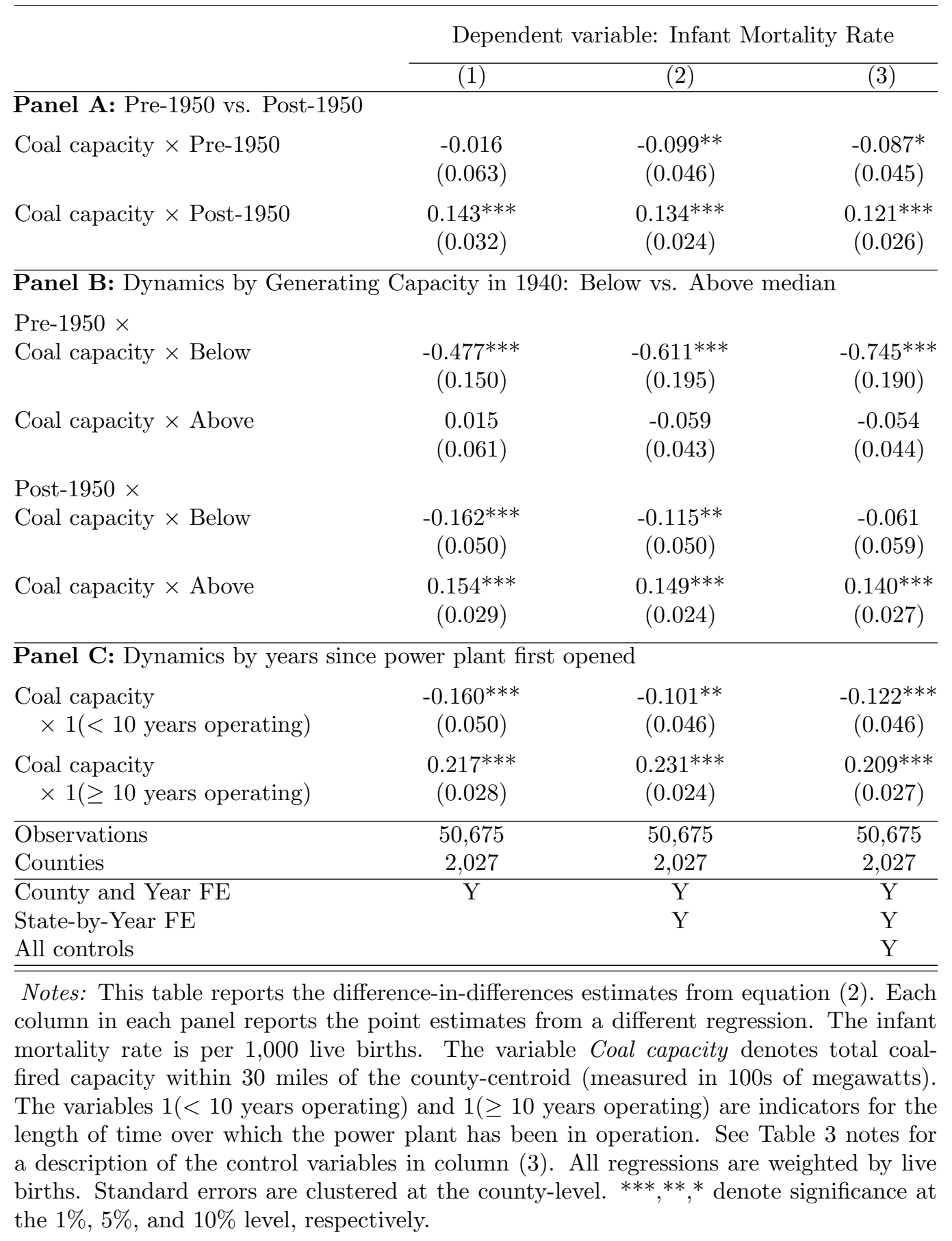




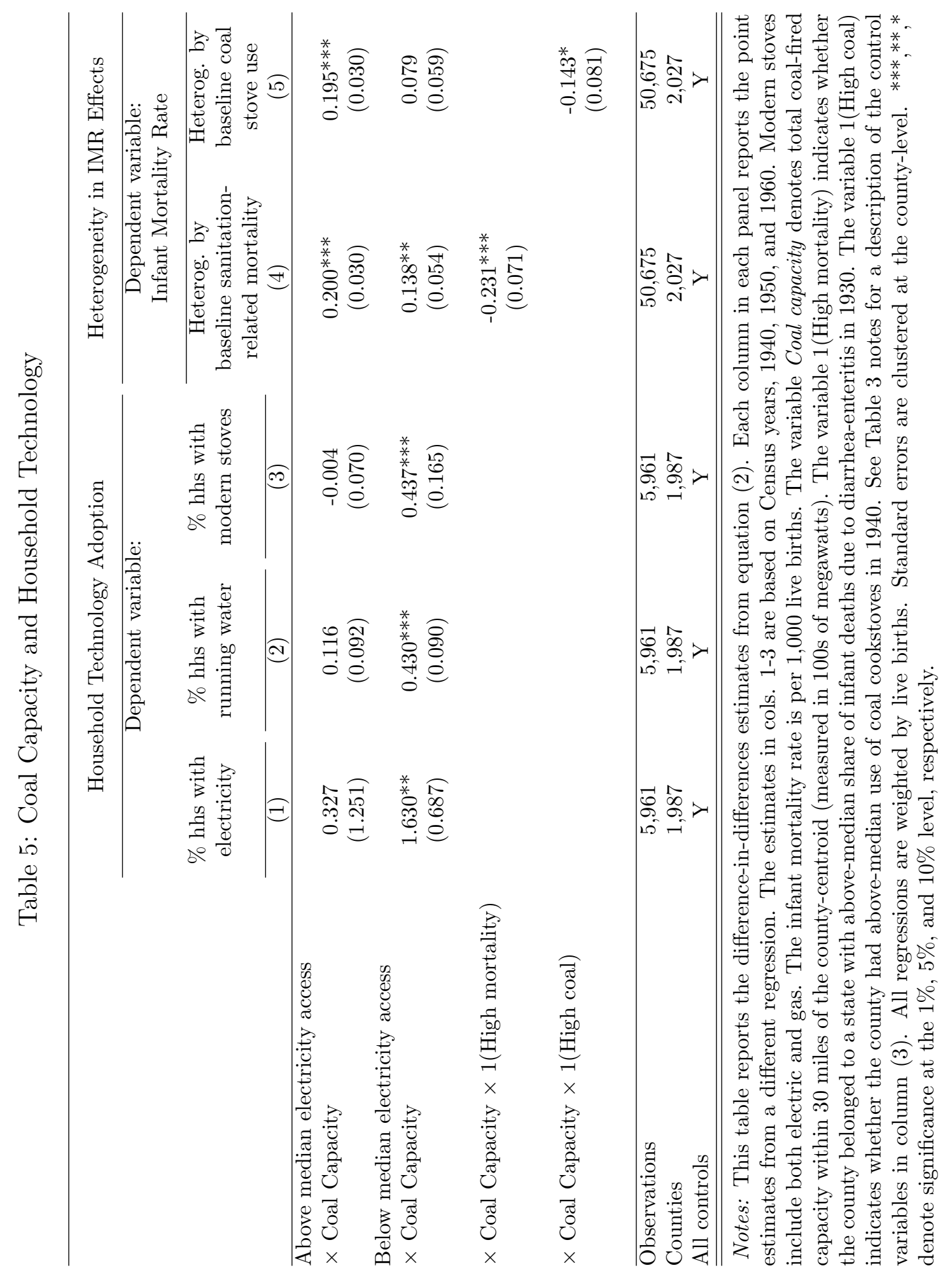




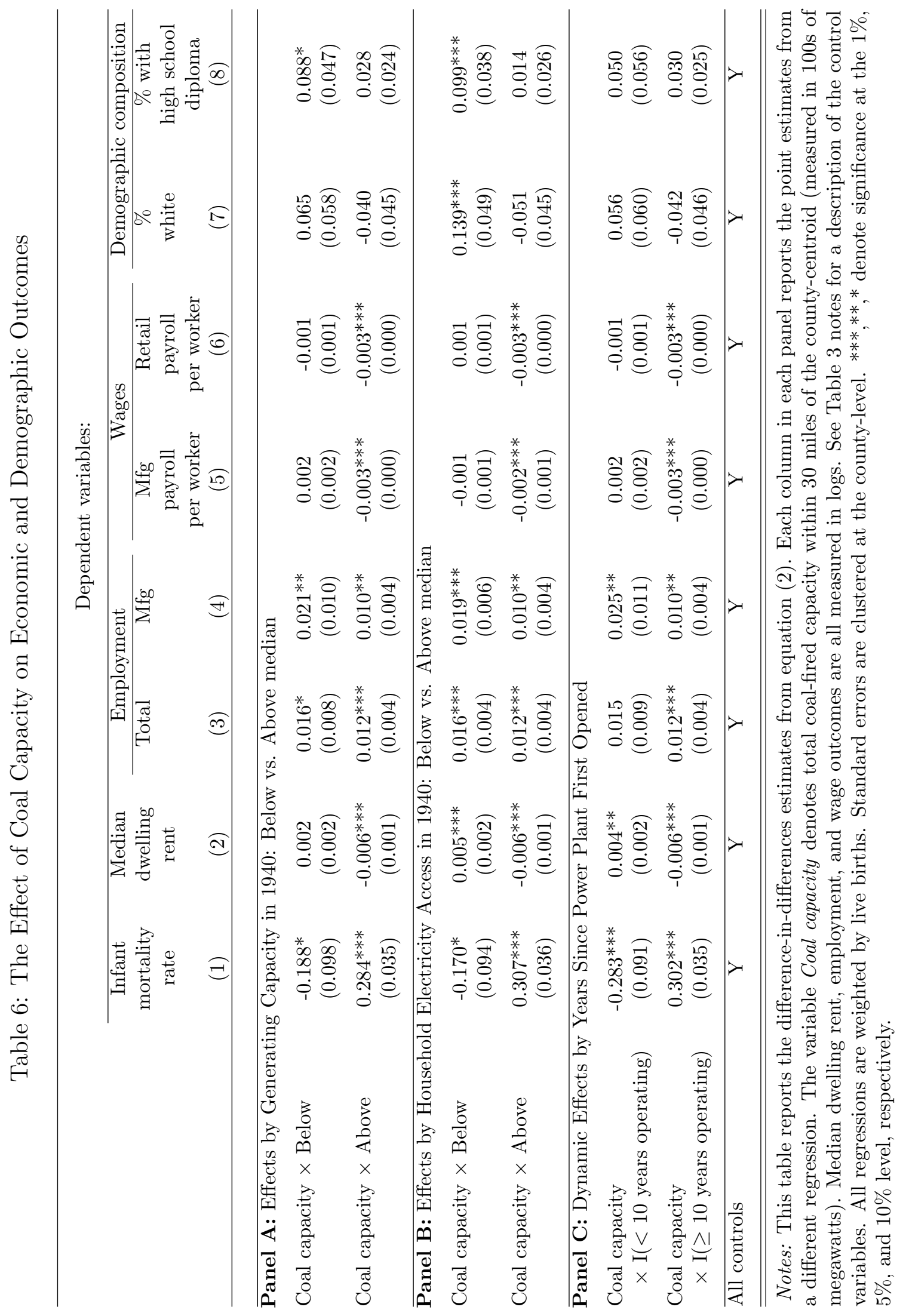


Table 7: Effects of Plant Openings by Pollution Exposure and Counterfactual Pollution Abatement Policies

\begin{tabular}{|c|c|c|c|}
\hline \multicolumn{4}{|c|}{ Panel A: Effects of plant openings, by AP3 estimated local air pollution } \\
\hline 1 (Plant Operating $) \times$ Near & \multicolumn{3}{|c|}{$\begin{array}{c}-0.499^{* *} \\
(0.236)\end{array}$} \\
\hline 1 (Plant Operating $) \times$ Near $\times$ & \multicolumn{3}{|c|}{$\begin{array}{c}0.441^{* * *} \\
(0.107)\end{array}$} \\
\hline $\begin{array}{l}\text { Observations } \\
\text { Counties } \\
\text { All Controls }\end{array}$ & & $\begin{array}{c}132,000 \\
1,969 \\
\mathrm{Y}\end{array}$ & \\
\hline \multicolumn{4}{|c|}{ Panel B: Counterfactual policies to reduce local air pollution } \\
\hline & $\begin{array}{l}\text { Installing Tall } \\
\text { Smoke Stacks }\end{array}$ & $\begin{array}{c}\text { Replacing Coal } \\
\text { with Hydro Capacity }\end{array}$ & Installing Baghouses \\
\hline$\%$ sulfate reduction & 95 & 100 & 99 \\
\hline Number of affected plants & 270 & 194 & 270 \\
\hline Infant lives saved per year & 1,709 & 1,035 & 1,781 \\
\hline Cost per life saved (1990 USD) & 520,000 & 670,000 & 170,000 \\
\hline
\end{tabular}

Notes: Panel A reports the estimates based on a generalized version of equation (1), in which we interact plant openings with local air pollution arising from plant emissions. The variable 'Near' is an indicator for counties within a 60 -mile radius of a plant, to capture the local benefits from electricity access (see Lewis, 2018). Estimates of local air pollution were obtained by combining annual power plant coal consumption with the AP3 air pollution model, which links the marginal contribution of emissions in a source county to ambient concentrations in every destination county (see Appendix B.3.1 and B.3.2 for details). Panel B reports the results from three counterfactual scenarios to reduce local exposure to plant emissions. The first is a mandate of tall smoke stacks for all coal-fired power plants (at least 200 meters in height), the second is the replacement of coal capacity with hydroelectric capacity that was built in the post-1962 period, and the third is a mandate that all coal-fired power plants install baghouses, a fabric filter technology available at the time that is still in use today. Implied decreases in infant deaths under each scenario are derived based on the AP3 results reported in Panel A (see Appendix B.3.3 for details). 
Figure 1: Trends in U.S. Electricity Generation and Coal Consumption

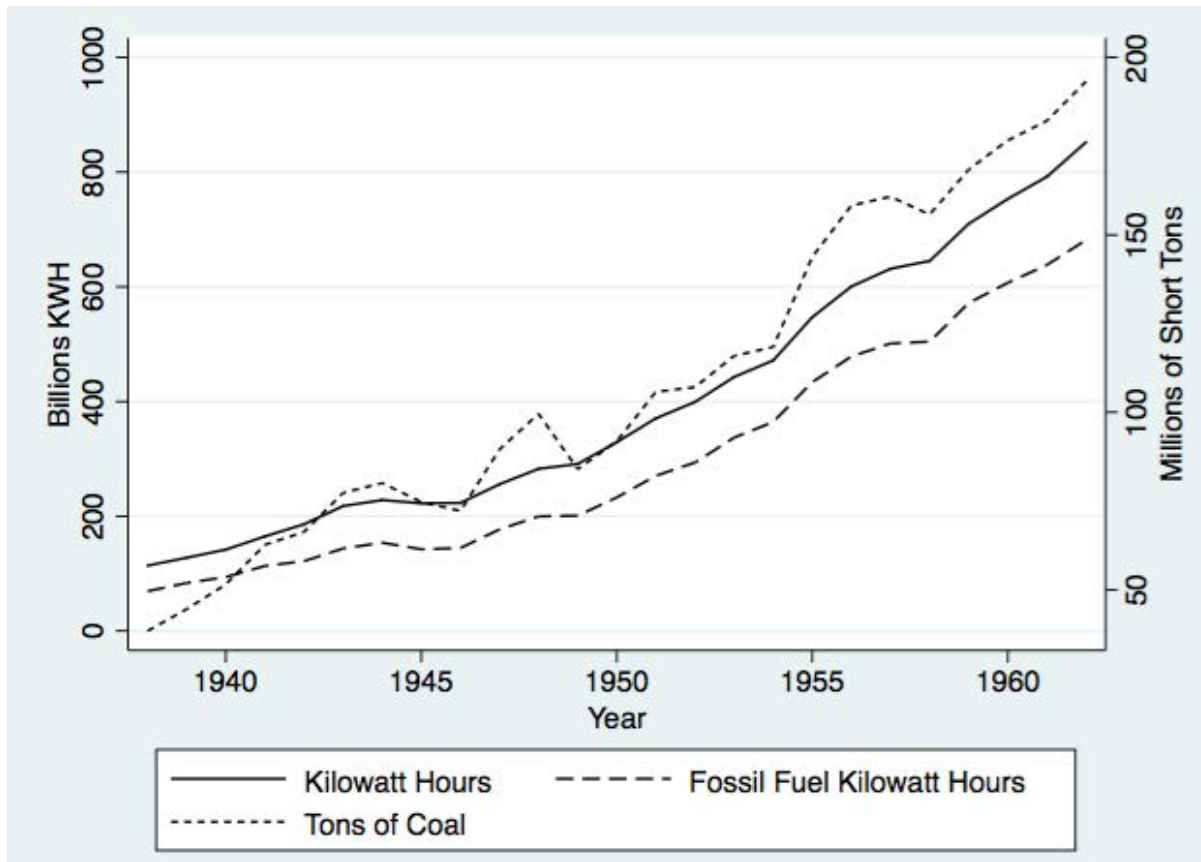

(a) Trends in Electricity Generation

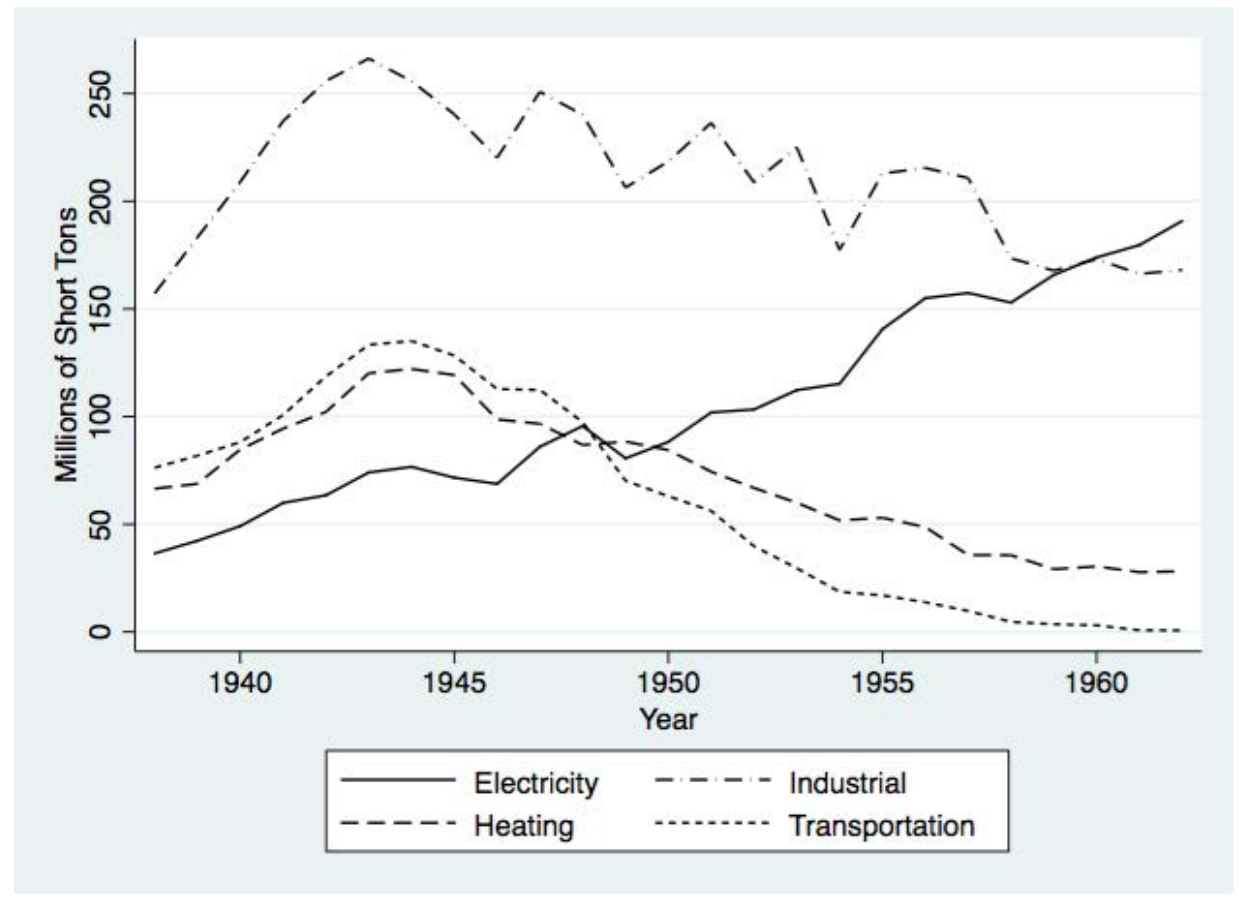

(b) Coal Consumption, by Source

Notes: (a) Data from Gartner (2006), Historical Statistics of the United States, Table Db218-227. Electric utilities-power generation and fossil fuel consumption by energy source: 1920-2000. (b) Data from United States Bureau of Mines, Minerals Yearbook (various years). 
Figure 2: Concentration of Airborne Sulfates By Distance to Coal-Fired Power Plants

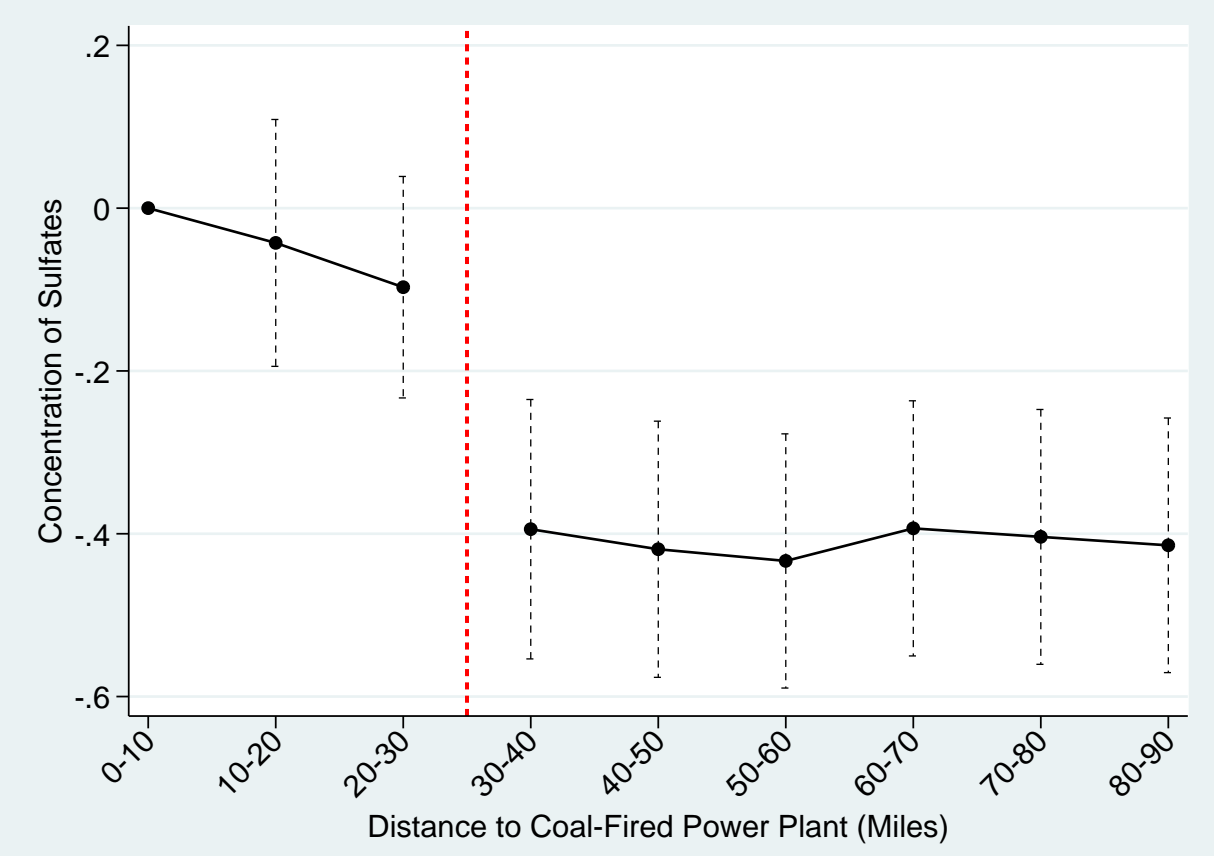

Notes: This figure plots the differential concentration of airborne sulfates, as measured by the AP3 model based on annual coal consumption by coal-fired power plants observed in our sample. These differentials are estimated by a simple regression of sulfates on indicators for distance ranges. 
Figure 3: Tradeoffs Associated with Coal-fired Electricity Generation

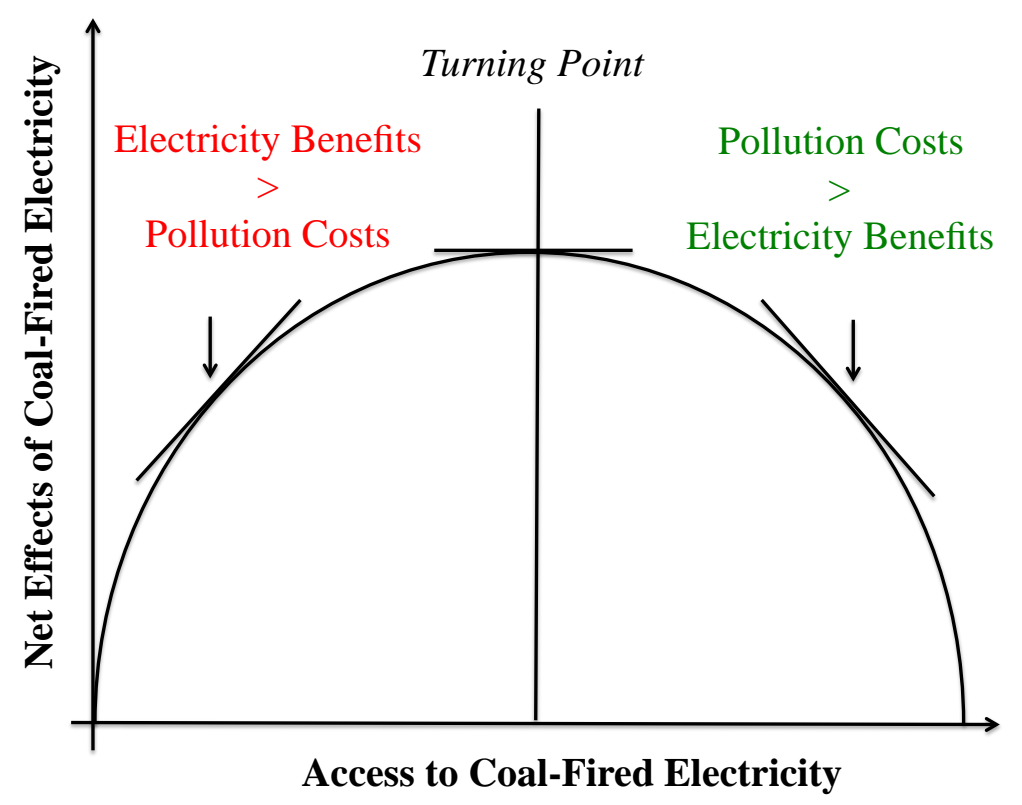

Notes: This figure illustrates the tradeoffs associated with the expansion of coalfired electricity access. Appendix B.1 provides a microfoundation for this invertedU shape. 
Figure 4: Power Plant Openings, Generating Capacity, and Coal Consumption

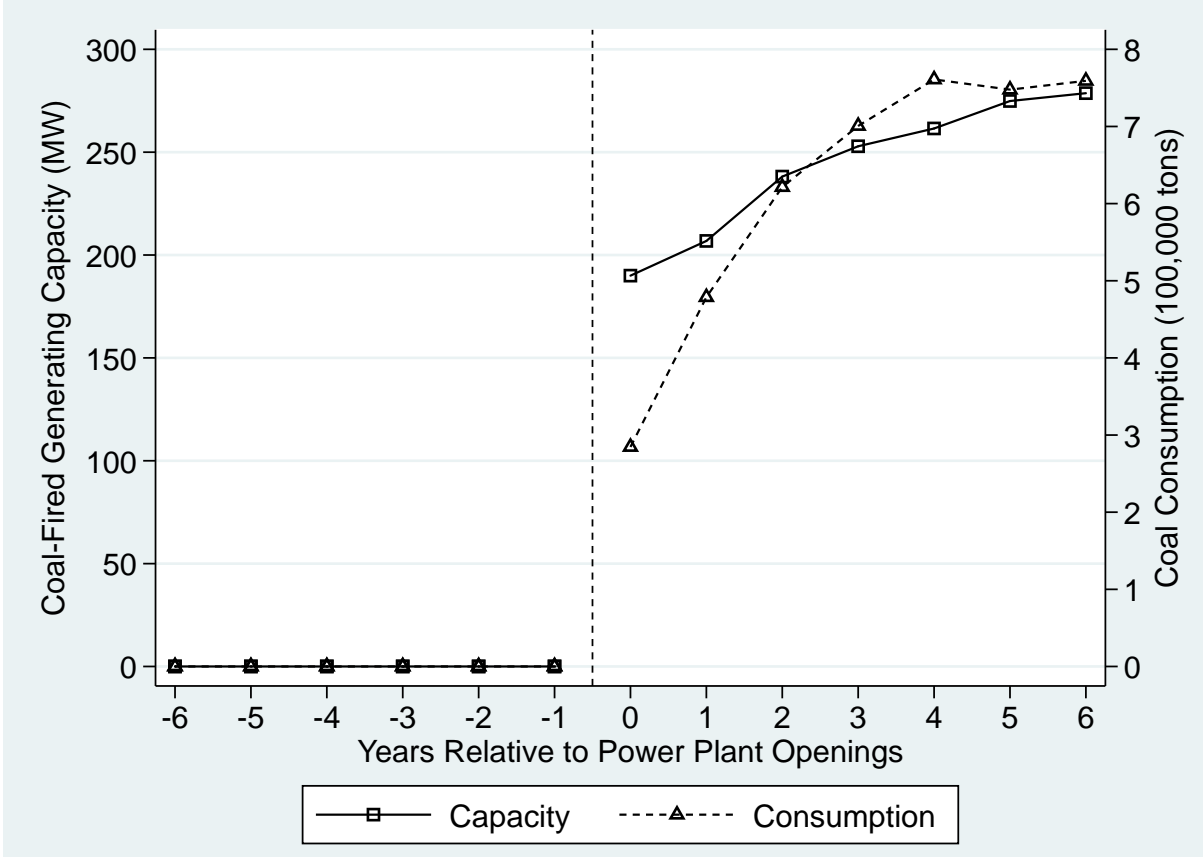

Notes: This figure reports coal-fired electricity generating capacity (in MWs) and coal consumption (in 100,000s of tons) for the 270 power plants that opened between 1938 and 1962 . 
Figure 5: Event Study: The Effect of Coal-Fired Power Plant Openings on Infant Mortality

(a) Below Median Generating Capacity in 1940

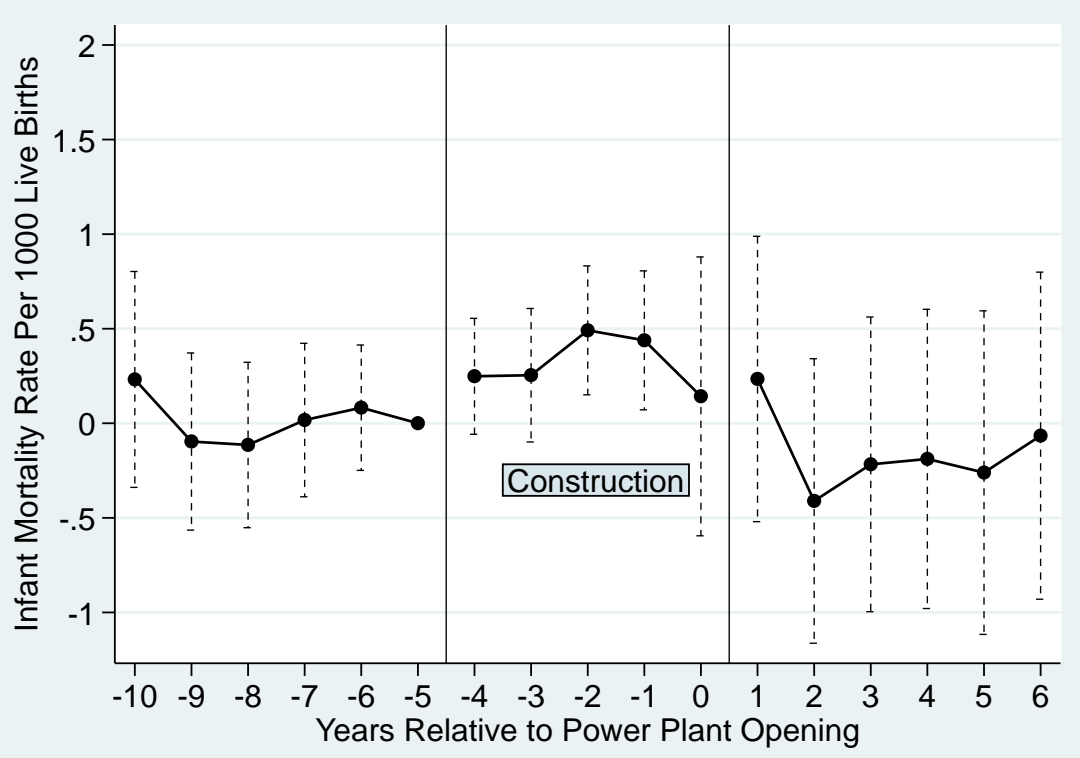

(b) Above Median Generating Capacity in 1940

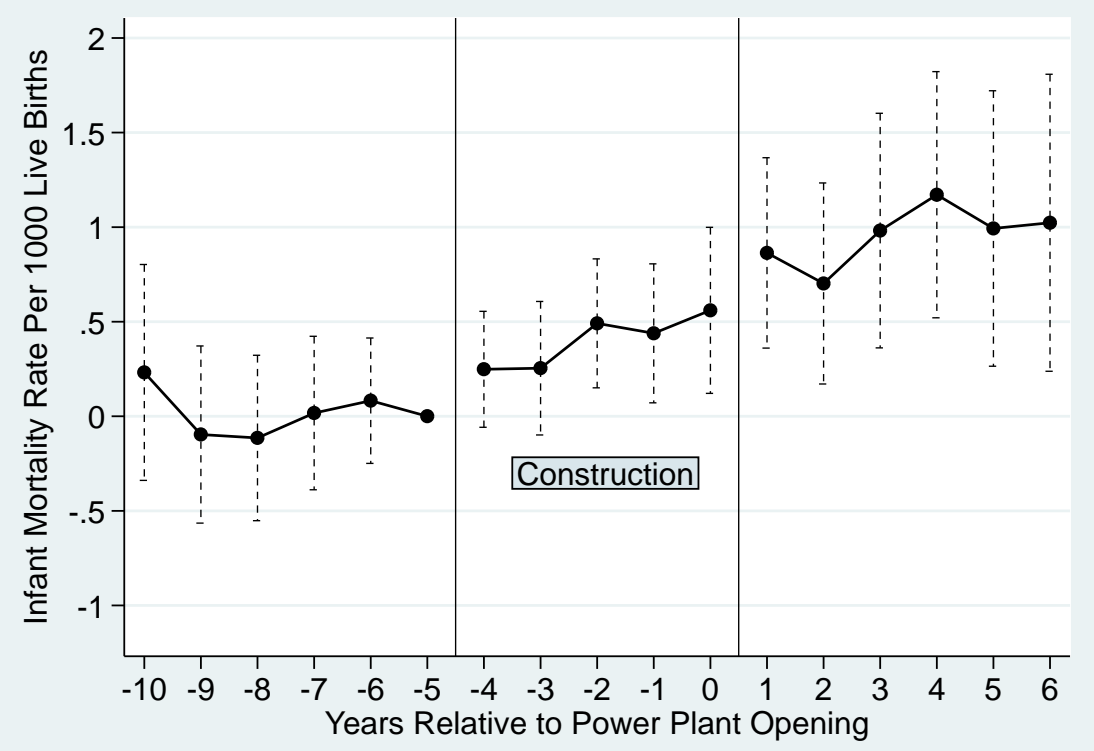

Notes: These figures report the event study estimates based on equation (1), in which the post-opening effects are allowed to differ across counties with below and above median generating capacity in 1940. The coefficients plot the time path of infant mortality in 'treatment' counties $(<30$ miles from a power plant) relative to 'control' counties (30-90 miles from a power plant). The period $t \in\{-10,-5\}$ identifies pre-construction, $t \in\{-4,0\}$ identifies likely construction, and $t \in\{1,6\}$ identifies post-opening. Following (Kline, 2012), we estimate the regression for the period $t \in\{-11,7\}$ and suppress the endpoint coefficients. Vertical dashed lines denote the $95 \%$ confidence intervals based on standard errors that are clustered at the county-level. 
Figure 6: Power Plant Openings and Installation at Existing Sites

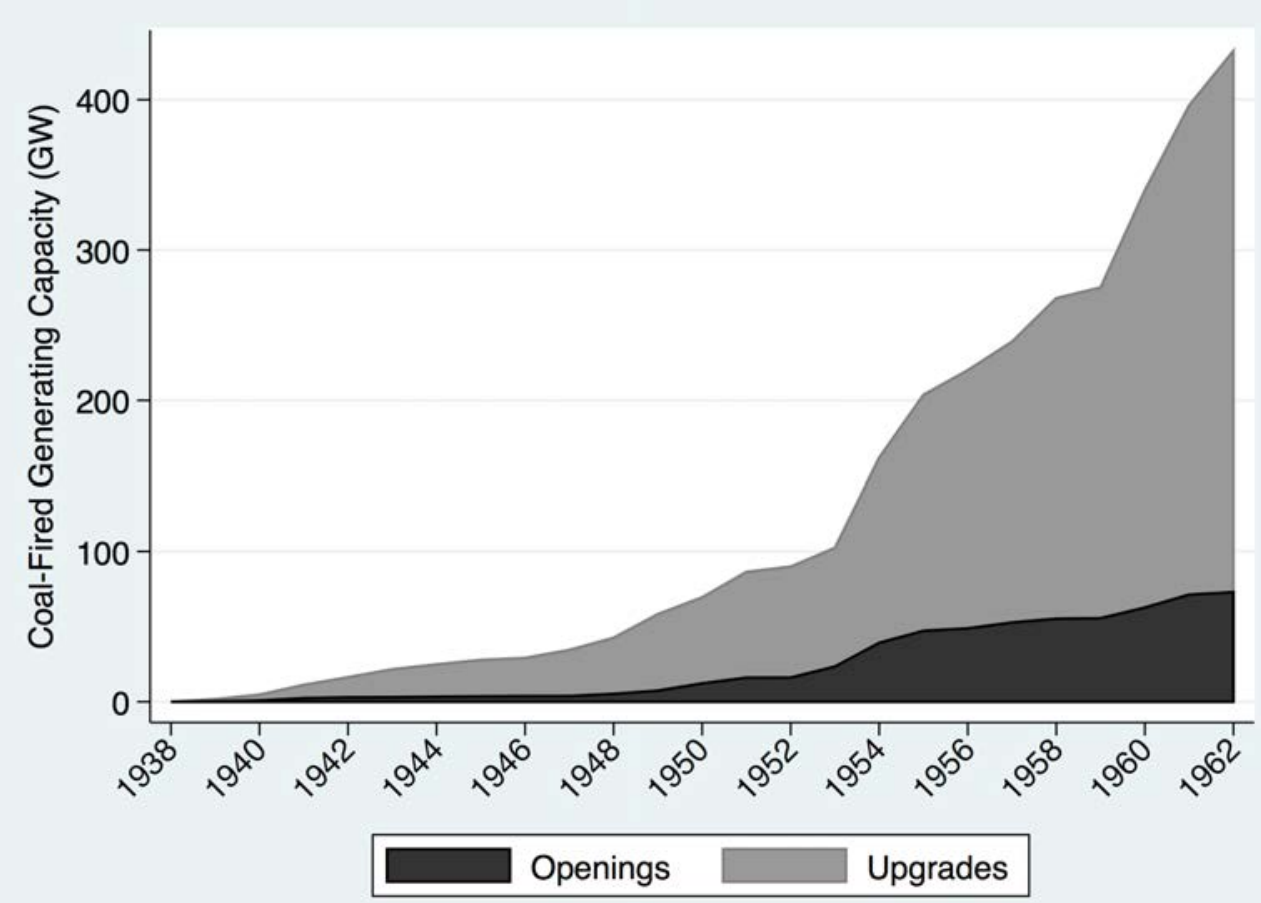

(a) Changes in generating capacity due to new openings and upgrades, 1938-1962
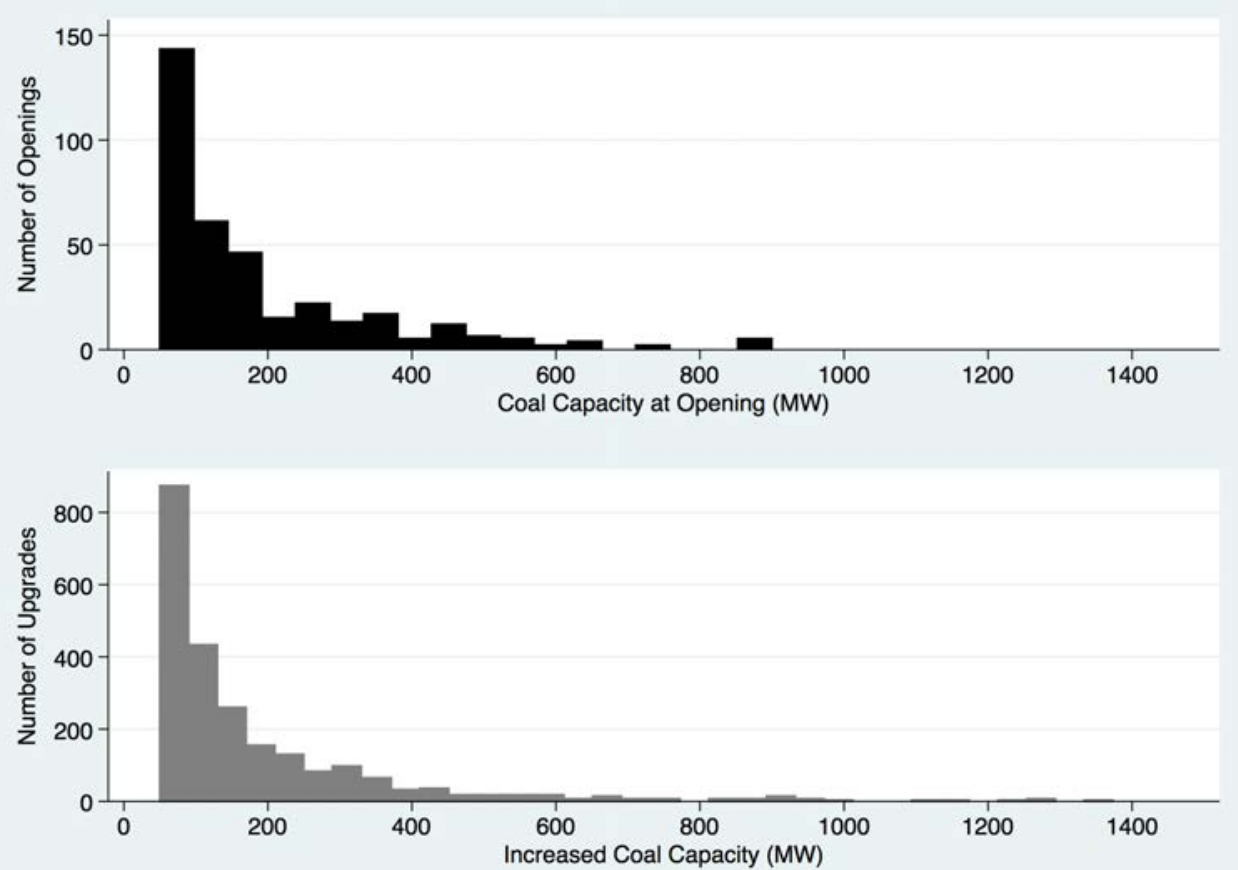

(b) Frequency of power plant openings and upgrades at existing sites, by size Notes: These figures depict the changes in coal-fired electricity generating capacity in our sample over the period 1938-1962, as well as the size distribution of new plant openings and upgrades at existing sites starting at 50MW. 
Figure 7: Effects of Plant Openings on Infant Mortality, by Air Pollution Concentration

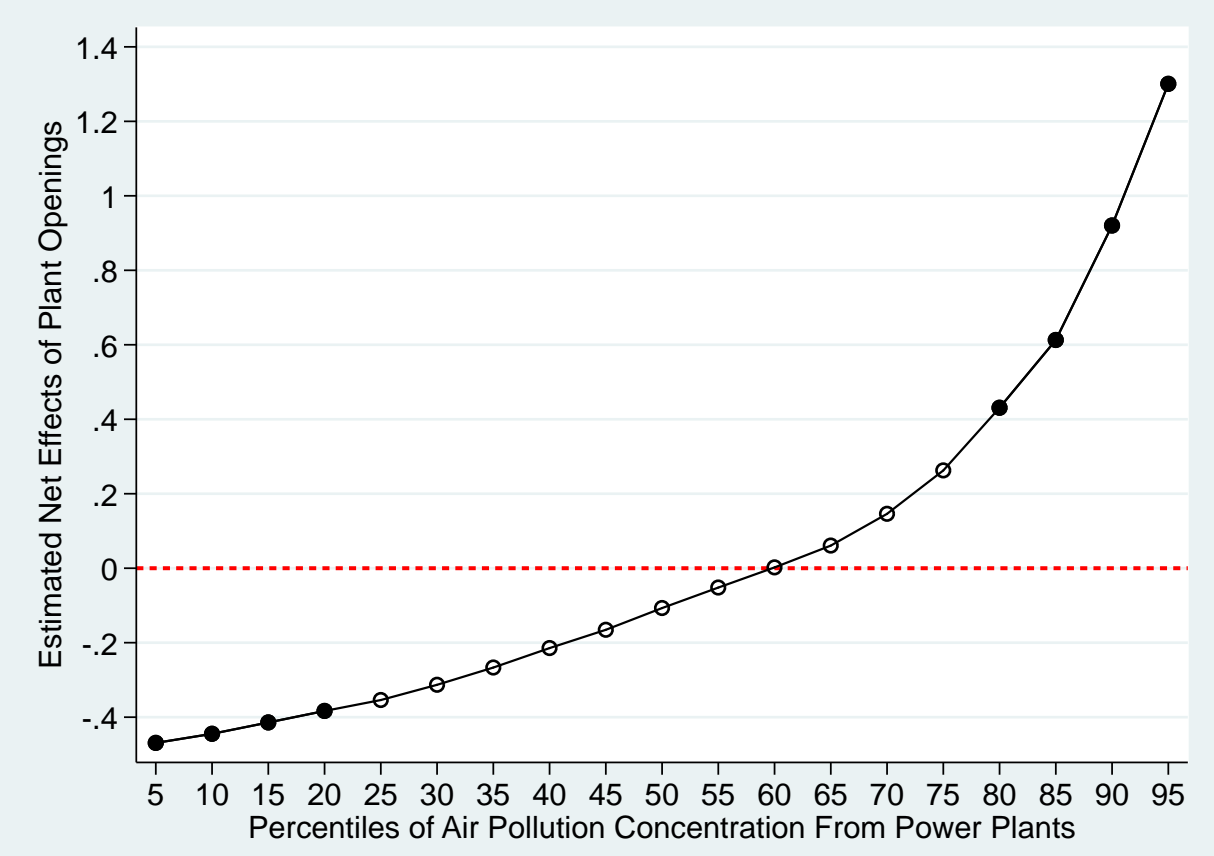

Notes: This figure plots the estimated net effects of coal-fired power plant openings on infant mortality by county percentiles of the air pollution concentrations. "Air pollution" means concentration of airborne sulfates, as measured by the AP3 model based on annual coal consumption by power plants observed in our sample. The solid circles denote significant net effects at 10 percent, the hollow circles represent effects that are not statistically significant. 


\section{A Appendix: Tables and Figures}

Table A.1: TSP Concentration in Various Years

\begin{tabular}{lccc}
\hline Location & Time & TSP & Source \\
\hline 14 Large US Cities & $1931-1933$, Winter & 510 & Ives et al. (1936) \\
US Urban Stations & $1953-1957$ & 163 & USHEW (1958a) \\
8 of 14 Large US Cities & 1954 & 214 & USHEW (1958a) \\
US Urban Stations & 1960 & 118 & Lave and Seskin (1972) \\
14 Large US Cities & 1960 & 143 & EPA data \\
& & & \\
US National Average & 1990 & 60 & Chay and Greenstone (2003a) \\
58 Chinese Cities & $1980-1993$ & 538 & Almond et al. (2009) \\
Worldwide & 1999 & 18\% of urban pop $>240$ & Cohen et al. (2004) \\
\hline \hline
\end{tabular}

Notes: The original measurements were in total suspended particulates (TSP) for all of the sources except for Cohen et al. (2004). Cohen et al., Figure 17.3 (World), indicates that 18\% of the urban population lived in locations where particulate matter (PM10) was greater than 100. We translated the PM10 values to TSP using the following formula: PM10/0.417, where 0.417 is the empirical ratio of PM10 to TSP in their world data (Table 17.4). The estimate for 1990 is from Chay and Greenstone (2003a), Figure 1. EPA data are authors' calculations based on EPA dataset for 1960. 
Table A.2: Characteristics of Power Plants and Surrounding Counties

\begin{tabular}{|c|c|c|c|c|}
\hline & \multicolumn{3}{|c|}{$\begin{array}{l}\text { Counties }<30 \text { miles } \\
\text { from power plant }\end{array}$} & \multirow{3}{*}{$\begin{array}{c}\text { Counties } \\
30-90 \text { miles } \\
\text { from } \\
\text { power plant } \\
(4) \\
\end{array}$} \\
\hline & \multirow{2}{*}{$\begin{array}{l}\text { All } \\
(1) \\
\end{array}$} & \multicolumn{2}{|c|}{$\begin{array}{c}\text { Above vs. below } \\
\text { median capacity, } 1940\end{array}$} & \\
\hline & & $\begin{array}{l}\text { Above } \\
(2)\end{array}$ & $\begin{array}{l}\text { Below } \\
(3)\end{array}$ & \\
\hline \multicolumn{5}{|c|}{ Panel A: Coal-fired power plant characteristics } \\
\hline Number & 270 & 96 & 174 & - \\
\hline Initial year of operation & 1952 & 1952 & 1952 & - \\
\hline Capacity (MWs) & 140.9 & 151.9 & 90.7 & - \\
\hline $\begin{array}{l}\text { Annual coal consumption } \\
\quad(100,000 \text { tons })\end{array}$ & 6.8 & 7.2 & 4.2 & - \\
\hline \multicolumn{5}{|l|}{ Panel B: County characteristics } \\
\hline Infant mortality rate & 29.1 & 28.6 & 31.4 & 31.1 \\
\hline Distance to power plant & 18.1 & 18.0 & 18.6 & 64.6 \\
\hline $\begin{array}{l}\text { Hydroelectric capacity } \\
<30 \text { miles (MWs) }\end{array}$ & 19 & 22 & 8 & 22 \\
\hline \multicolumn{5}{|l|}{ Baseline characteristics, 1940} \\
\hline Employment $(1,000 \mathrm{~s})$ & 320 & 395 & 26 & 34 \\
\hline$\%$ Manufacturing employment & 29.1 & 32.0 & 18.0 & 19.6 \\
\hline Population (1,000s) & 842 & 1,037 & 76 & 102 \\
\hline$\%$ Urban & 70.3 & 78.2 & 39.2 & 38.4 \\
\hline \% Households with electricity & 88.4 & 94.1 & 66.3 & 66.9 \\
\hline Railroad mileage, 1911 & 198.7 & 219.4 & 117.7 & 112.4 \\
\hline Predicted interstate highway, 1944 & 0.80 & 0.87 & 0.49 & 0.50 \\
\hline Counties & 734 & 251 & 483 & 1,235 \\
\hline $\mathrm{N}$ (plant-county pairs) & 1,056 & 469 & 587 & 4,224 \\
\hline Observations & 26,400 & 11,725 & 14,675 & 105,600 \\
\hline
\end{tabular}

Notes: This table reports summary statistics for the event-study sample. Panel A describes the mean characteristics of the 270 coal-fired power plants that opened between 1938 and 1962 . Panel B describes the sample means for the treatment and control counties. All means are weighted by the number of live births. 
Table A.3: Summary Statistics, Coal Capacity Analysis

\begin{tabular}{|c|c|c|c|}
\hline & \multirow[b]{2}{*}{$\begin{array}{c}\text { All } \\
\text { counties } \\
(1)\end{array}$} & \multicolumn{2}{|c|}{$\begin{array}{c}\text { Above vs. below } \\
\text { median capacity, } 1940\end{array}$} \\
\hline & & $\begin{array}{c}\text { Above } \\
(2)\end{array}$ & $\begin{array}{c}\text { Below } \\
(3)\end{array}$ \\
\hline \multicolumn{4}{|l|}{ Panel A: Outcome variables } \\
\hline $\begin{array}{l}\text { Infant mortality rate } \\
\quad \text { Mean } \\
\text { Change, 1962-1938 }\end{array}$ & $\begin{array}{c}30.4 \\
-19.82\end{array}$ & $\begin{array}{c}29.1 \\
-20.86\end{array}$ & $\begin{array}{c}32.0 \\
-19.54\end{array}$ \\
\hline $\begin{array}{l}\text { Median dwelling rent } \\
\text { per month, } 1990 \$\end{array}$ & 240.6 & 272.3 & 200.3 \\
\hline $\begin{array}{l}\text { Manufacturing payroll } \\
\text { per worker }\end{array}$ & 17.7 & 19.8 & 14.9 \\
\hline $\begin{array}{l}\text { Retail payroll } \\
\text { per worker }\end{array}$ & 12.5 & 13.3 & 11.3 \\
\hline$\%$ White & 89.1 & 89.9 & 88.2 \\
\hline$\%$ High School (age 25+) & 34.0 & 36.9 & 30.3 \\
\hline \multicolumn{4}{|l|}{ Panel B: Coal and hydro generation } \\
\hline $\begin{array}{l}\text { Coal capacity <30 miles (100 MWs) } \\
\text { Mean } \\
\text { Change, 1962-1938 }\end{array}$ & $\begin{array}{l}5.94 \\
3.33\end{array}$ & $\begin{array}{c}10.00 \\
9.38\end{array}$ & $\begin{array}{l}0.70 \\
1.69\end{array}$ \\
\hline $\begin{array}{l}\text { Coal consumption }<30 \text { miles }(100 \mathrm{~K} \\
\quad \text { Mean } \\
\text { Change, } 1962-1938\end{array}$ & $\begin{array}{l}10.24 \\
2.27\end{array}$ & $\begin{array}{c}17.35 \\
6.84\end{array}$ & $\begin{array}{l}1.05 \\
1.04\end{array}$ \\
\hline $\begin{array}{l}\text { Hydro capacity }<30 \text { miles }(100 \text { MW } \\
\quad \text { Mean } \\
\quad \text { Change, 1962-1938 }\end{array}$ & $\begin{array}{l}0.28 \\
0.15\end{array}$ & $\begin{array}{l}0.40 \\
0.21\end{array}$ & $\begin{array}{l}0.12 \\
0.14\end{array}$ \\
\hline \multicolumn{4}{|c|}{ Panel C: Baseline Characteristics, 1940} \\
\hline Population $(1,000 \mathrm{~s})$ & 456 & 835 & 69 \\
\hline$\%$ Urban & 52.0 & 70.5 & 33.1 \\
\hline Employment $(1,000 \mathrm{~s})$ & 171 & 316 & 23 \\
\hline \% Manufacturing Employment & 23.0 & 30.0 & 15.8 \\
\hline \% Households with Electricity & 74.8 & 89.2 & 60.3 \\
\hline Mileage of Railroads, 1911 & 155.7 & 201.0 & 109.5 \\
\hline Predicted Interstate Highway, 1944 & 0.63 & 0.83 & 0.42 \\
\hline Number of Counties & 2,027 & 431 & 1,596 \\
\hline
\end{tabular}

Notes: This table reports the characteristics for the sample of 2,027 counties used to estimate equation (2). Sample means are reported separately according to whether counties had above or below median generating capacity in 1940. All means are weighted by the number of live births. All dollar amounts are reported in 1990 dollars. 
Table A.4: Total Suspended Particulates (TSP) Concentration and Coal Capacity, 1957-1962

\begin{tabular}{|c|c|c|}
\hline & \multicolumn{2}{|c|}{$\begin{array}{c}\text { Dependent variable: } \\
\text { Total Suspended Particulates }\end{array}$} \\
\hline & $(1)$ & $(2)$ \\
\hline Coal capacity ( $\leq 30$ miles) & $\begin{array}{r}2.3245^{* *} \\
(1.0228)\end{array}$ & \\
\hline Coal capacity ( $\leq 50$ miles) & & $\begin{array}{c}2.2378^{* * *} \\
(0.6451)\end{array}$ \\
\hline Observations & 433 & 433 \\
\hline Counties & 85 & 85 \\
\hline R-squared & 0.723 & 0.753 \\
\hline Mean dep var in 1957 & & \\
\hline Mean dep var in 1962 & & \\
\hline State-by-Year FE & $\mathrm{Y}$ & $\mathrm{Y}$ \\
\hline Geographic Controls & $\mathrm{Y}$ & $\mathrm{Y}$ \\
\hline
\end{tabular}

Notes: This table reports the relationship between coal-fired electricity generating capacity and total suspended particulates (TSP), a measure of particulate matter collected by the EPA for the period 1957-1962. 


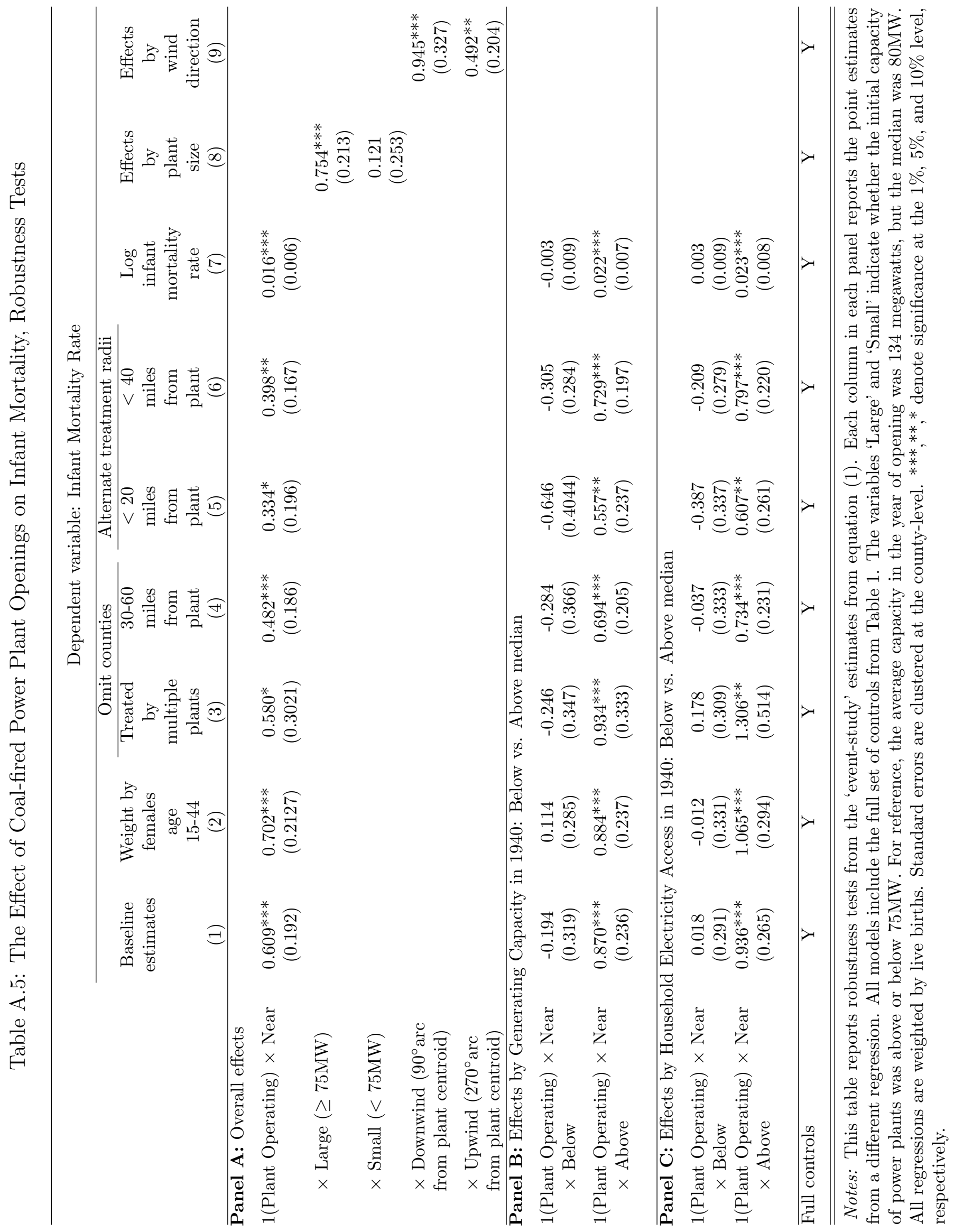


Table A.6: Oster Tests for Significant Coefficients in Table 1

\begin{tabular}{|c|c|c|c|c|}
\hline Variable of Interest & Estimate & $\begin{array}{l}\text { Maximum } \\
\quad \mathrm{R} 2\end{array}$ & Delta & $\begin{array}{c}\text { Coefficent Bounds } \\
{[\text { Delta }=0, \text { Delta }=1]}\end{array}$ \\
\hline \multicolumn{5}{|l|}{ Panel A: Overall effects } \\
\hline 1(Plant Operating $) \times$ Near & 0.609 & 0.883 & -0.111 & {$[0.609,14.190]$} \\
\hline \multicolumn{5}{|c|}{ Panel B: Effects by Generating Capacity in 1940: Below vs. Above Median } \\
\hline 1 (Plant Operating $) \times$ Near $\times$ Above & 0.87 & 0.883 & -0.341 & {$[0.870,4.030]$} \\
\hline \multicolumn{5}{|c|}{ Panel C: Effects by Household Electricity Access in 1940: Below vs. Above Median } \\
\hline $1($ Plant Operating $) \times$ Near $\times$ Above & 0.936 & 0.883 & -0.244 & {$[0.936,5.971]$} \\
\hline
\end{tabular}

Notes: This table presents the results of the Oster test. The first column reproduces the significant coefficients in Table 1, column 3. The second column reports the maximally attainable R2 of 1.3 times the R2 of the specification with all the controls Oster (2019). The third column shows the estimate of the parameter $\delta$, which indicates how much larger the selection on unobservables would have to be, compared to the selection on observables, for the true causal effect to be zero. The fourth column reports the estimated bounds of the main coefficients of interest for different values of the relative degree of the selection on observed and unobserved variables $(\delta)$. Following Oster (2019), we focus on $\delta=0$ corresponding to the original estimate, and $\delta=1$ as the upper bound under the assumption of equal selection between observed and unobserved variables. Both the estimated $\delta \mathrm{s}$ and the estimated upper bounds are relative to a generalized difference-in-differences model with no additional controls, i.e., a model that includes only county-plant-pair fixed effects and state-by-year fixed effects. 


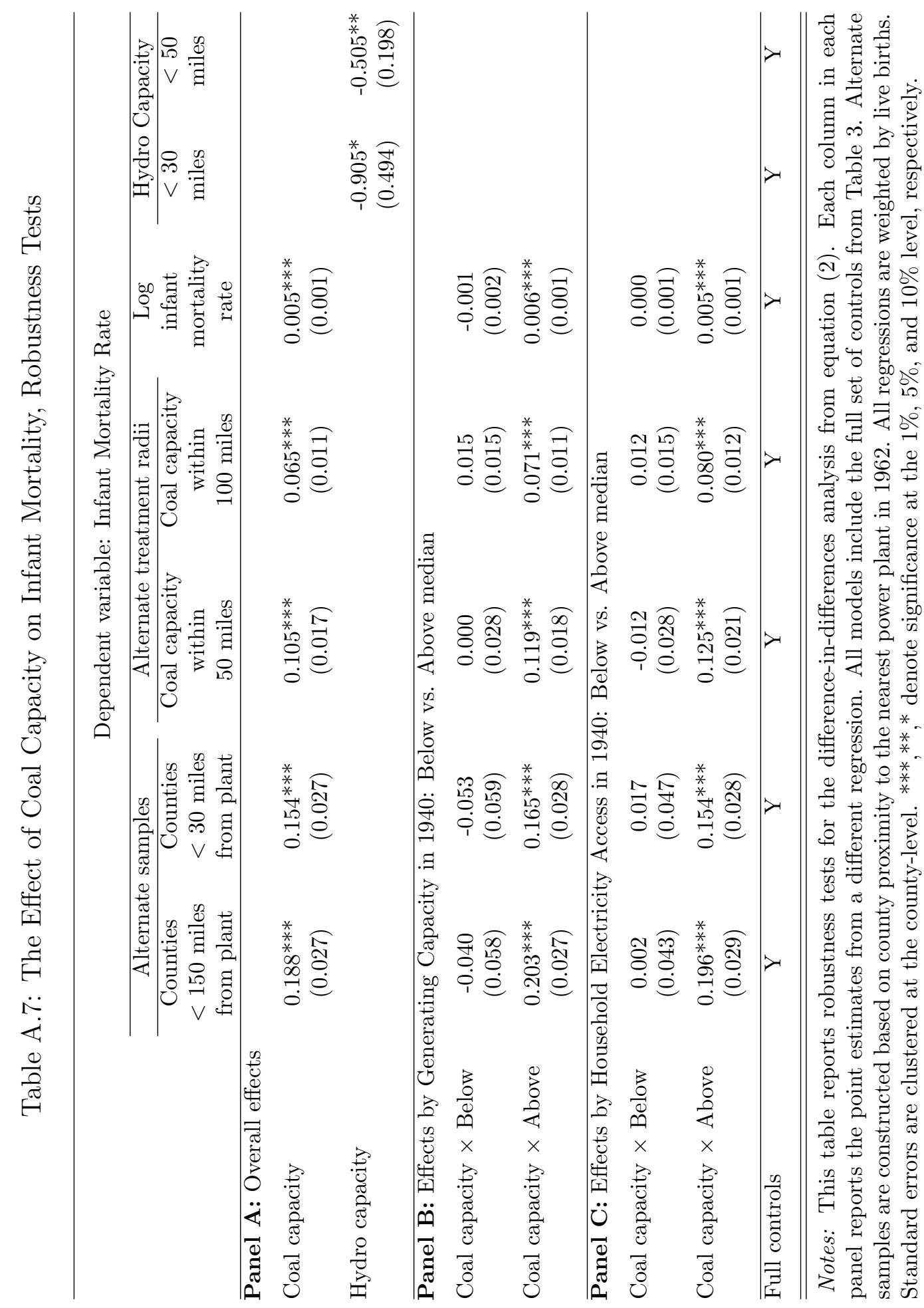


Figure A.1: Cumulative Dispersion of $\mathrm{PM}_{2.5}$ Around Large Coal-Fired Power Plants

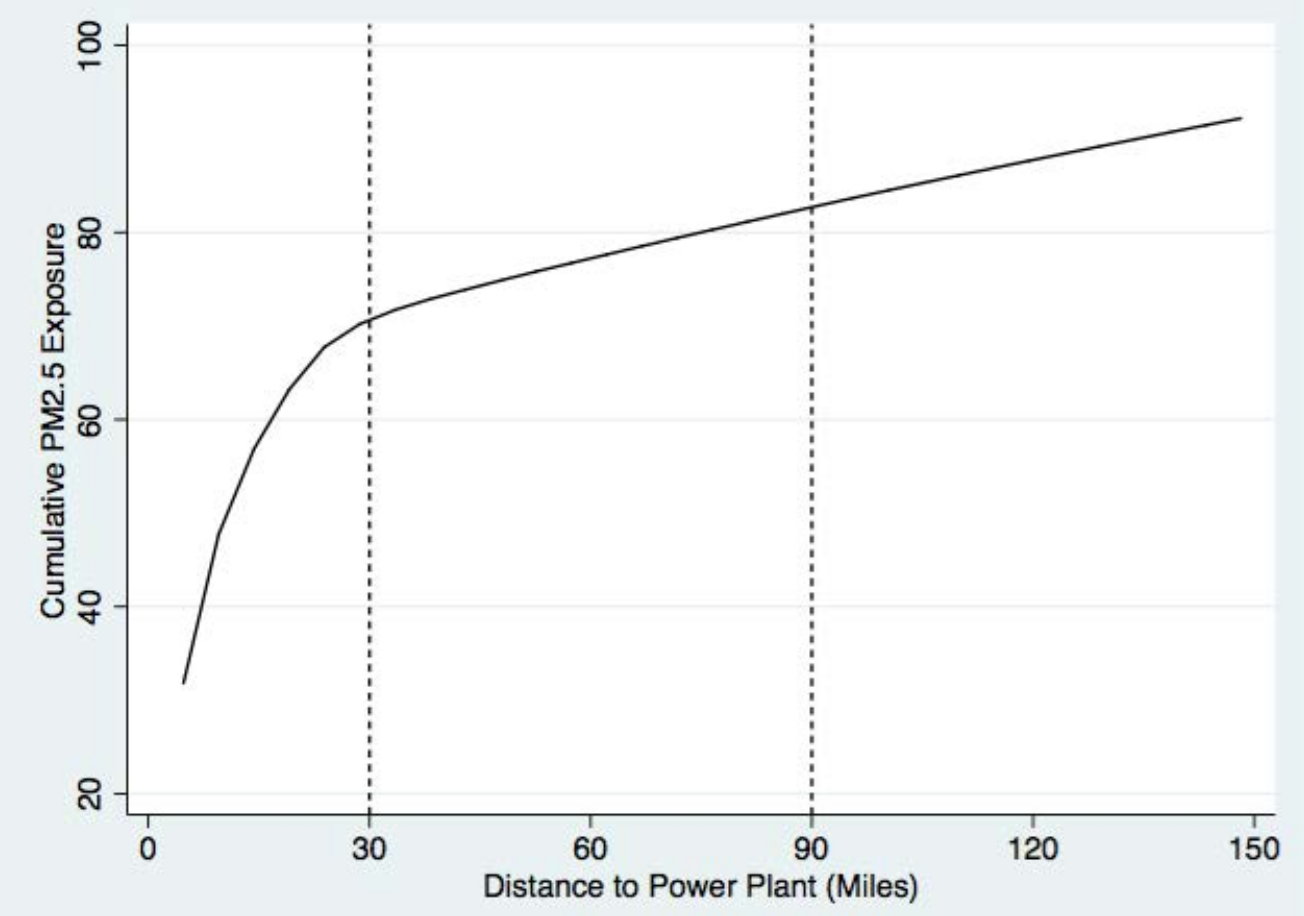

Notes: This figure shows the cumulative exposure to particulate matter by distance to large coal-fired power plants (Levy et al., 2002). 
Figure A.2: Trends in Power Plant Smoke Stack Height and Electrical Generating Capacity

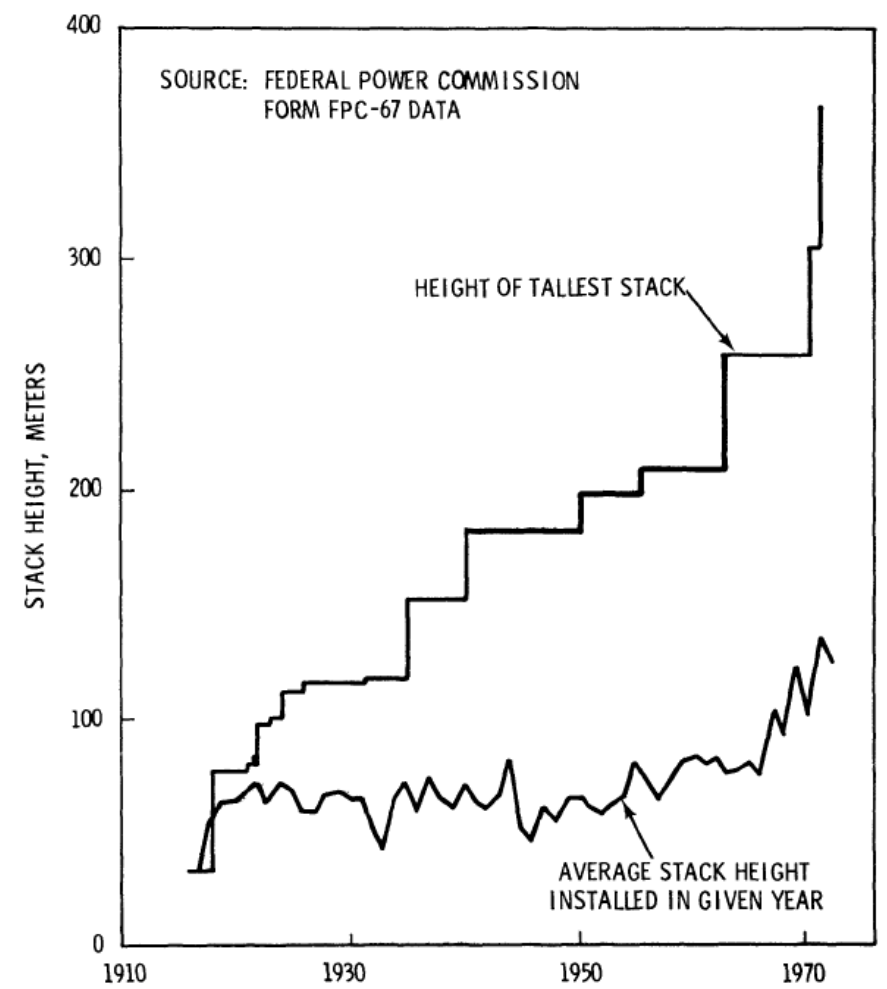

(a) Stack Height of Newly Installed Power Plants

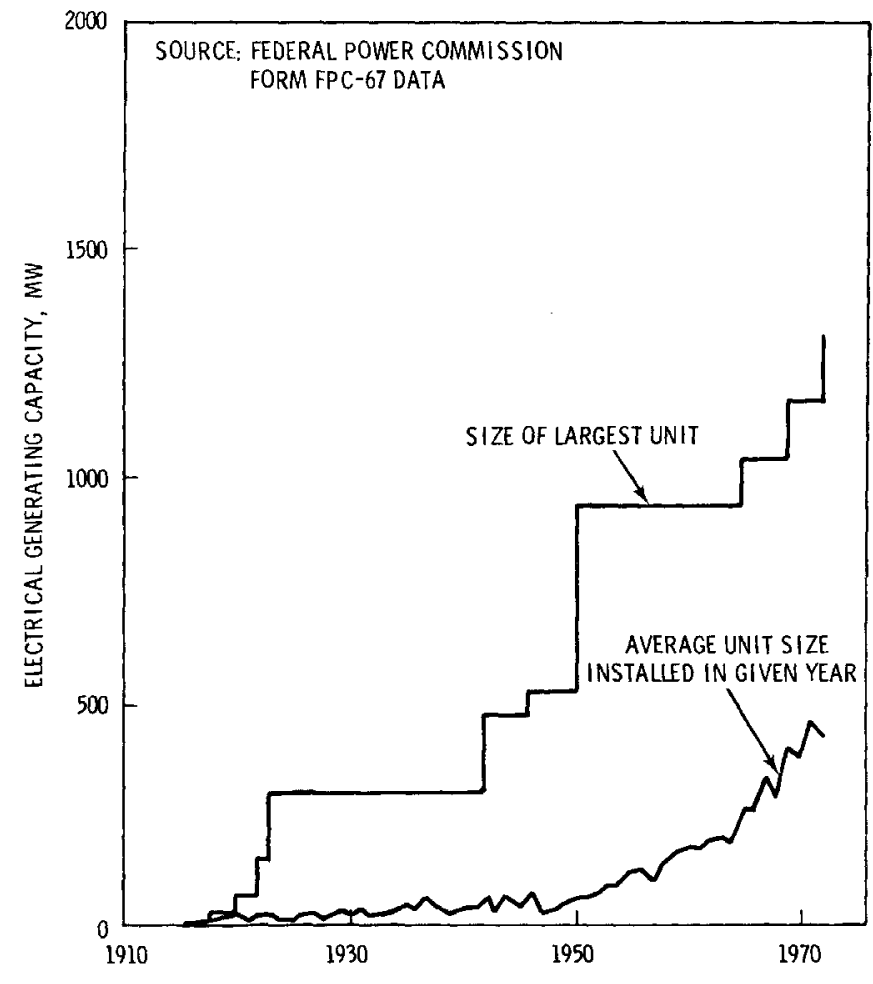

(b) Capacity of Newly Installed Power Plants

Notes: From Hales (1976). 
Figure A.3: Event Study Sample

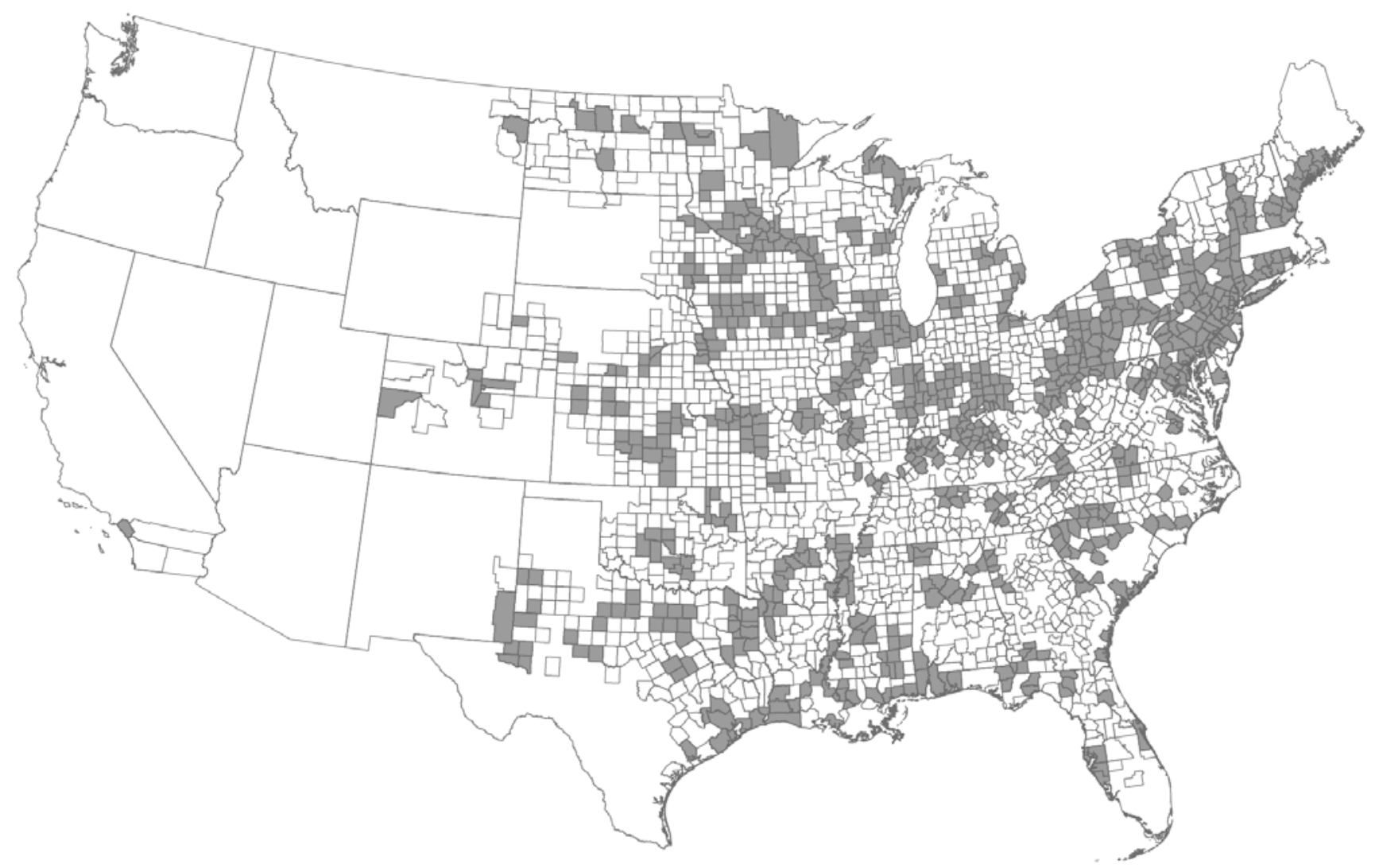

Notes: This figure depicts the sample for the event-study analysis. White outlines identify 'control' counties located 30 to 90 miles from a power plant opening. Grey shades identify 'treatment' counties located within 30 miles of a power plant opening from 1938 to 1962. 
Figure A.4: Coal Capacity Sample

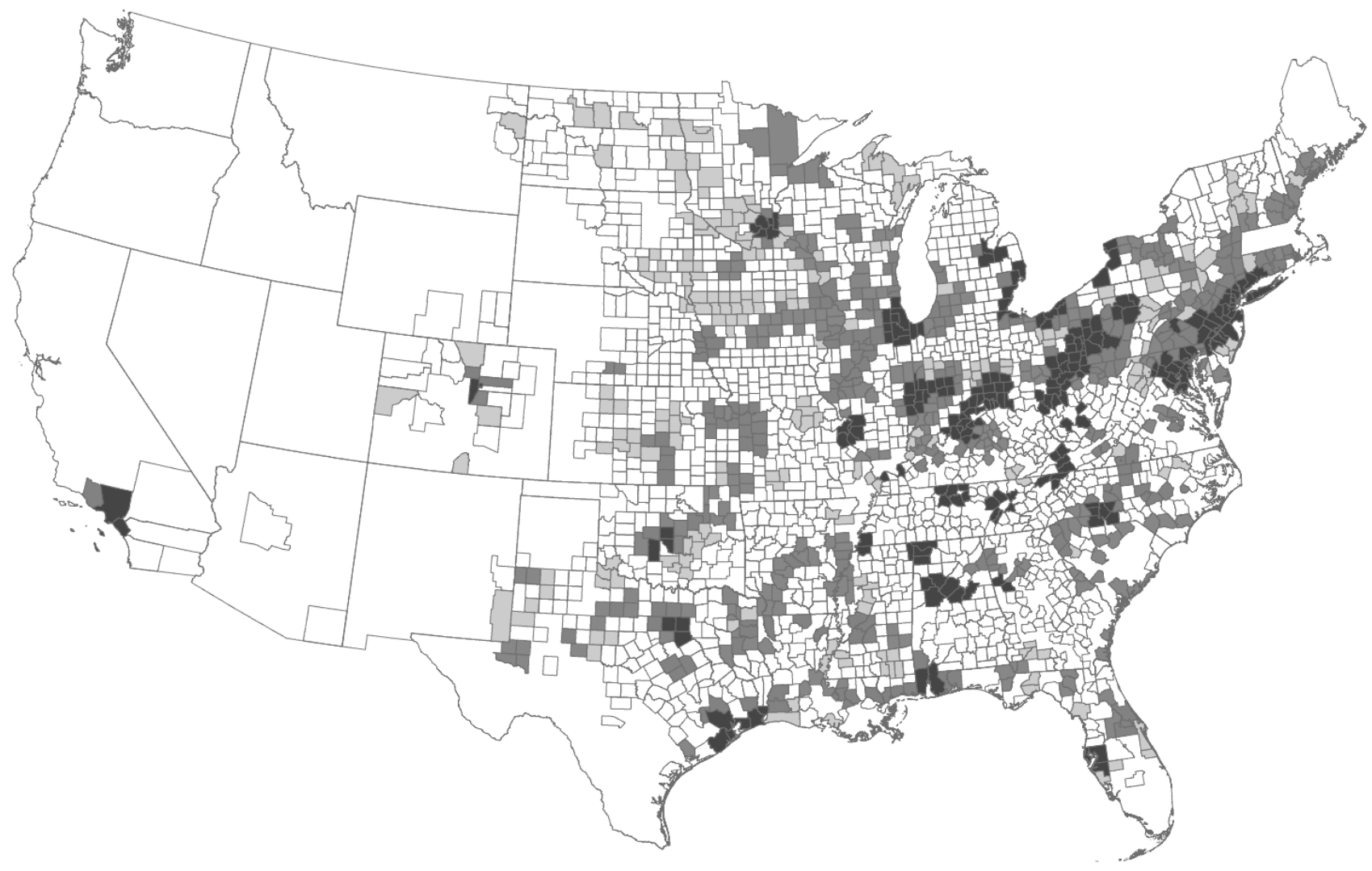

Notes: This figure depicts the sample for the difference-in-differences analysis. White outlines identify counties located 30 to 90 miles from a capacity change. Shaded counties identify counties within 30 miles of a capacity change from 1938 to 1962. Shaded counties are classified according to quartile of change ( $<88 \mathrm{MW}, 88-263 \mathrm{MW}, 263-617 \mathrm{MW},>617 \mathrm{MW})$, where darker shades indicate larger capacity increases. 
Figure A.5: Event Study: The Effect of Coal-Fired Power Plant Openings on Infant Mortality

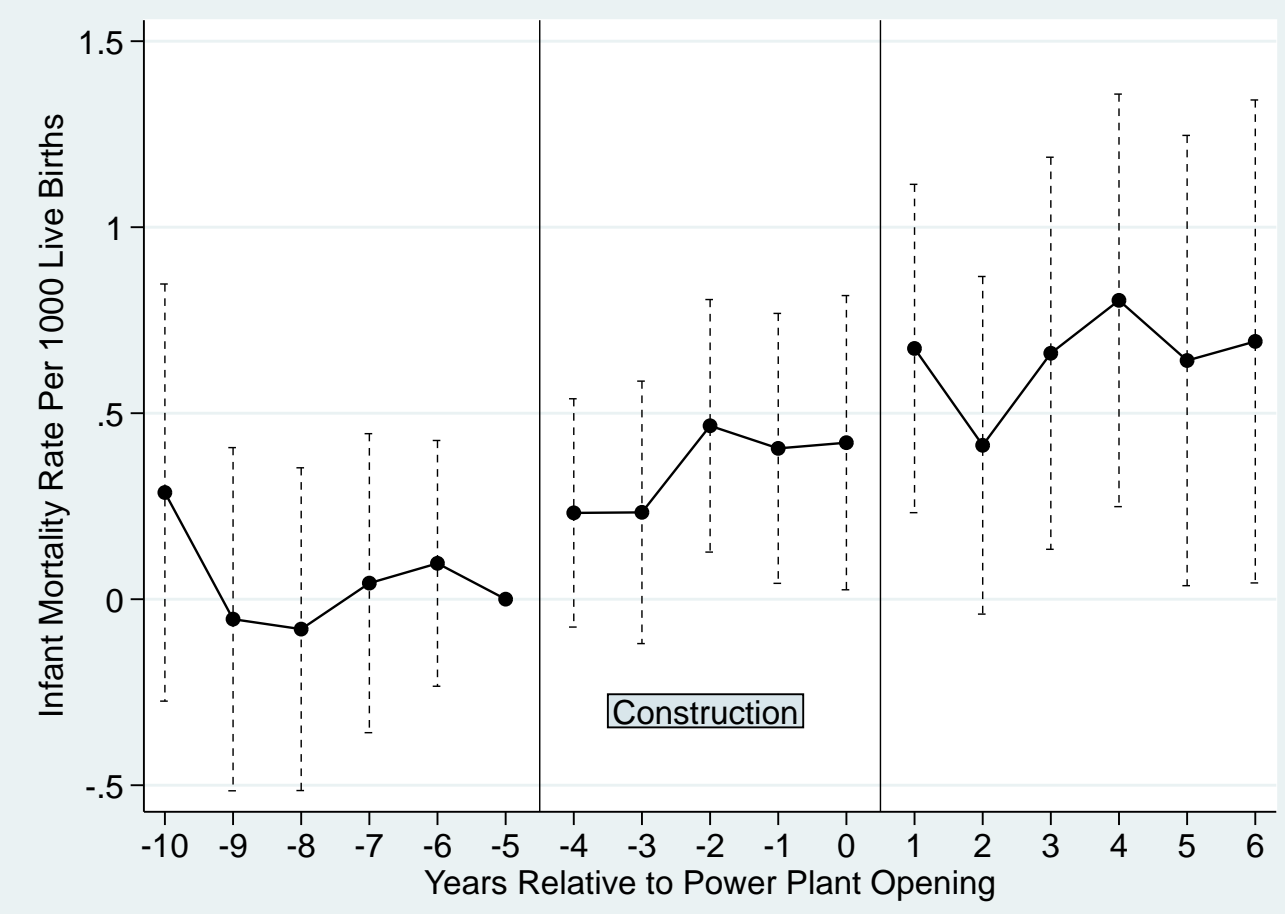

Notes: This figure reports the event study estimates based on equation (1). The coefficients plot the time path of infant mortality in 'treatment' counties $(<30$ miles from a power plant) relative to 'control' counties (30-90 miles from a power plant). The period $t \in\{-10,-5\}$ identifies pre-construction, $t \in\{-4,0\}$ identifies likely construction, and $t \in\{1,6\}$ identifies post-opening. Following (Kline, 2012), we estimate the regression for the period $t \in\{-11,7\}$ and suppress the endpoint coefficients. Vertical dashed lines denote the $95 \%$ confidence intervals based on standard errors that are clustered at the county-level. 
Figure A.6: Event Study: The Effect of Coal-Fired Power Plant Openings on Infant Mortality

(a) Below Median \% Households w/ Electricity Access in 194C

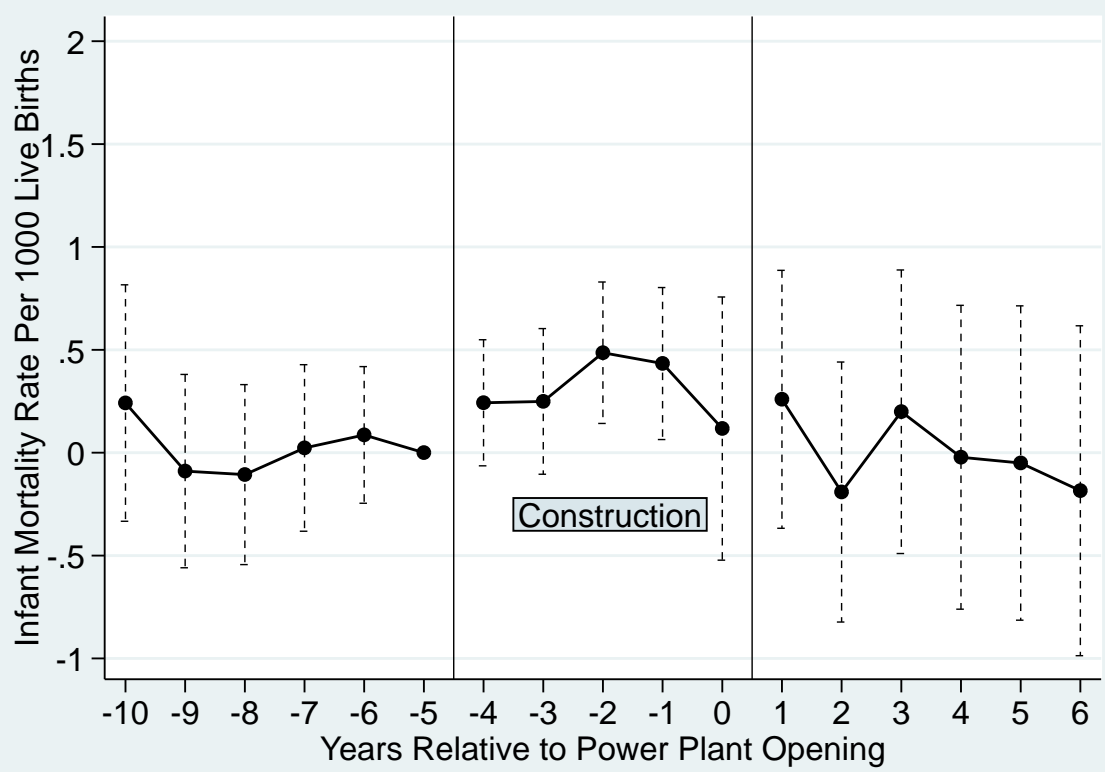

(b) Above Median \% Households w/ Electricity Access in 1940

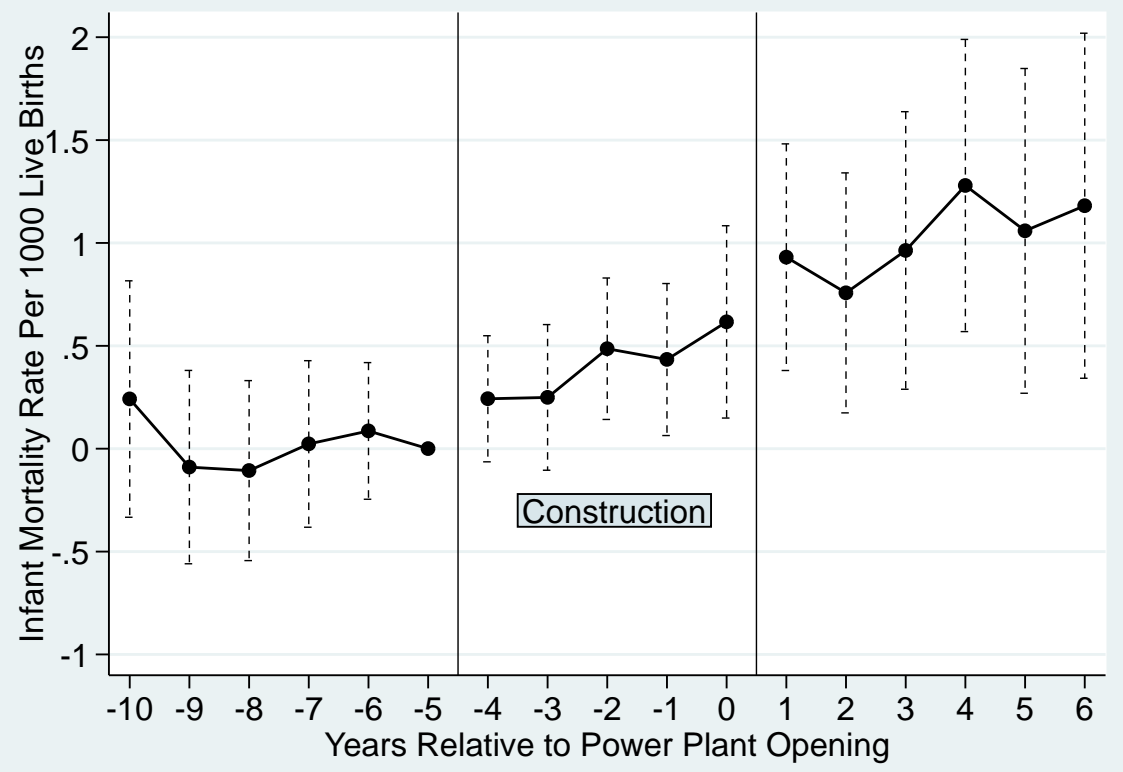

Notes: These figures report the event study estimates based on equation (1), separately for counties with below and above median percentage of households with electricity access in 1940. The coefficients plot the time path of infant mortality in 'treatment' counties $(<30$ miles from a power plant) relative to 'control' counties (30-90 miles from a power plant). The period $t \in\{-10,-5\}$ identifies pre-construction, $t \in\{-4,0\}$ identifies likely construction, and $t \in\{1,6\}$ identifies post-opening. Following (Kline, 2012), we estimate the regression for the period $t \in\{-11,7\}$ and suppress the endpoint coefficients. Vertical dashed lines denote the $95 \%$ confidence intervals based on standard errors that are clustered at the county-level. 
Figure A.7: Trends in Infant Mortality by Baseline Coal Capacity, 1938-1962

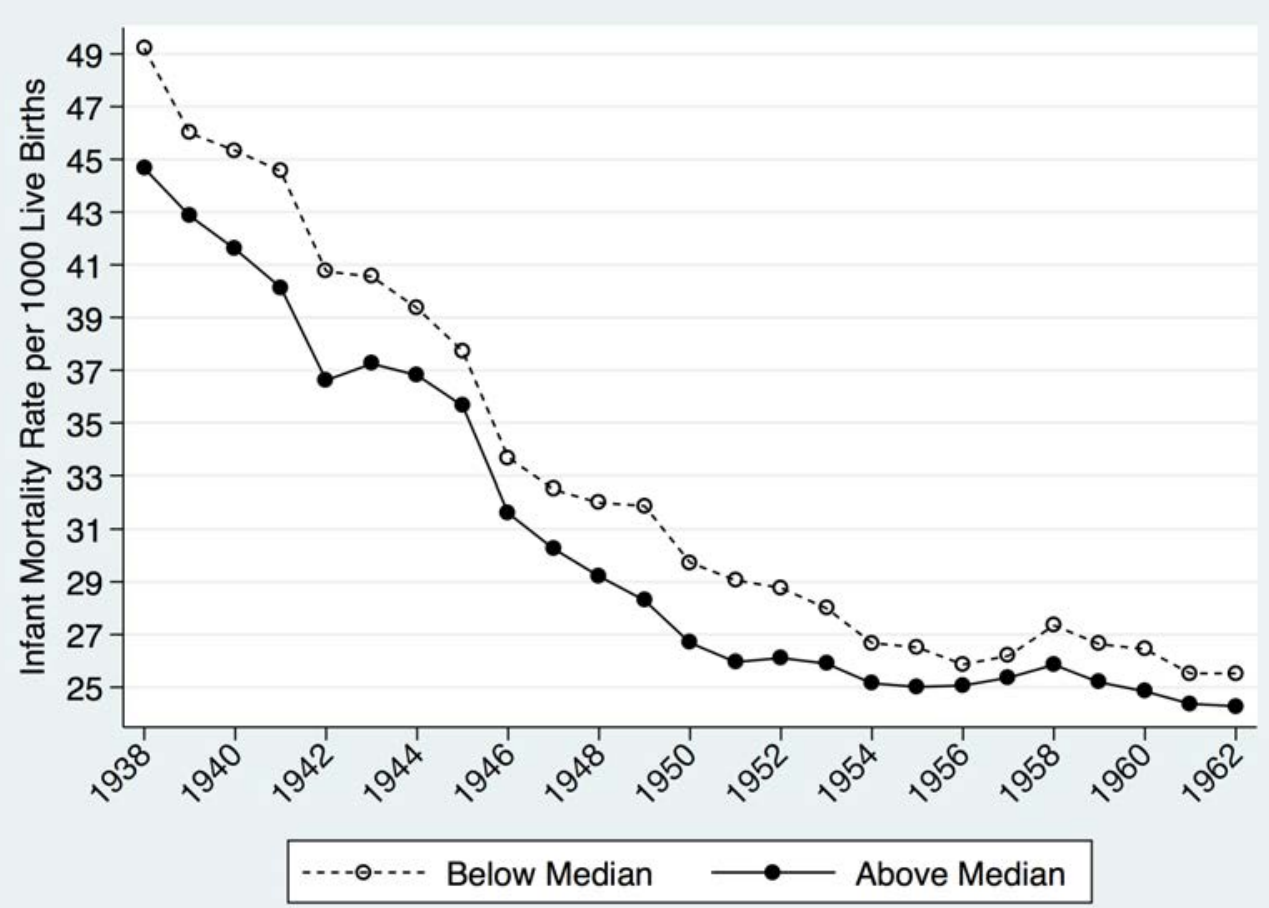

Notes: This figure plots the mean infant mortality rate from 1938 to 1962, separately for counties above and below the 1940 median coal-fired electricity generating capacity. Sample means are weighted by live births. 


\section{B Appendix: Additional Information}

\section{B.1 Conceptual Framework}

We develop a simple partial equilibrium model to study the health impacts of expansions in coal-fired generating capacity. We assume that a representative consumer of a U.S. county has a concave utility function over electricity $(E)$, health $(H)$, and a composite good that we call shelter $(S)$. We also assume that health is a function of air quality $(A)$ and access to electricity $(E)$, and that there is a market for electricity and shelter, but not for air quality. Finally, we assume that air quality is directly affected by coal-fired power generation. The consumer's problem is:

$$
\operatorname{Max}_{E, S \in \mathbb{R}_{+}^{2}} U(E, H, S) \quad \text { s.t. } \quad d E+r S=Y, \quad H \equiv H(A, E), \quad A \equiv A(E),
$$

where $d$ and $r$ represent prices of electricity and shelter, respectively, $Y$ income, $H_{A} \geq 0$ the slope of the pollution-mortality concentration-response function, $H_{E} \geq 0$ the marginal impact of electricity access on health, $A_{E} \leq 0$ the effect of a marginal increase in coal-fired power generation on air quality. To simplify, we define $E$ as the share of hours of the day that the representative consumer uses electricity. An expansion of coal-fired power generation allows the consumer to increase her use of electricity during the day.

The first order conditions to the consumer's problem are given by:

$$
U_{E}+U_{H} \cdot\left(H_{A} A_{E}+H_{E}\right)=\frac{d U_{S}}{r}
$$

Since $U_{E}, U_{H}$, and $U_{S}$ are all positive, a tradeoff between electricity access and air pollution exists only if $A_{E}$ and $H_{A}$ are both non-zero. ${ }^{53}$ That is, the tradeoff exists only if air pollution increases with electricity generation $\left(A_{E}<0\right)$, and health outcomes deteriorate with polluion $\left(H_{A}>0\right)$. When both conditions are met, the impact of welfare consequences of coal-fired generation will depend on the level of electricity access. At low levels of access, the marginal benefit of an increase in generation will tend to outweigh the pollution costs. As a result of concavity, the marginal benefit will decrease as electricity production increases, and eventually be outweighed by the pollution costs. This simple setup provides a microfoundation for the relationship depicted in Figure 3.

\footnotetext{
${ }^{53}$ Notice that this setup is a variation of Greenstone and Jack (2015)'s framework used to evaluate why developing countries have a low marginal willingness to pay for environmental quality. One of their leading explanation is that, due to low income levels, citizens of those countries value increases in income more than marginal improvements in environmental quality.
} 


\section{B.2 Power Plant Data Construction}

We have digitized power plant level data from the Federal Power Commission reports for the years 1938-1962. These are the titles of the reports:

1938-1947: Steam-Electric Plant Construction Cost and Annual Production Expenses, 19381947

1948-1962: Steam-Electric Plant Construction Cost and Annual Production Expenses (Annual Supplements)

As an example, we present a page from the 1957 report:

\begin{tabular}{|c|c|c|c|c|c|c|c|c|c|}
\hline \multirow{2}{*}{\begin{tabular}{l|} 
Nane \\
Line. \\
No.
\end{tabular}} & \multicolumn{3}{|c|}{$\begin{array}{l}\text { NEW BEDPCRD GAS } \\
\text { AND BDISOI LIGET } \\
\text { COMPNTY }\end{array}$} & \multicolumn{6}{|c|}{ CONBUNERS POUER COMPANY } \\
\hline & $\begin{array}{l}\text { Nenes of Plant } \\
\text { Region and Power Supply Area } \\
\text { Location of Plant }\end{array}$ & \multicolumn{2}{|c|}{$\begin{array}{c}\text { Cannon Stroet } \\
\text { I-2 } \\
\text { Nev Bedford, Mase. }\end{array}$} & \multicolumn{2}{|c|}{$\begin{array}{c}\text { B. C. Cobb } \\
\text { II }-11 \\
\text { Mukcegan, M1ch. }\end{array}$} & \multicolumn{2}{|c|}{$\begin{array}{l}\text { Bryce B. Morrow } \\
\text { II-11 } \\
\text { Kalnmaroo, M1ch. }\end{array}$} & \multicolumn{2}{|c|}{$\begin{array}{l}\text { 8aginav RIver } \\
\text { II-11 } \\
\text { 211waukee, Mich. }\end{array}$} \\
\hline $\begin{array}{l}1 \\
2 \\
3 \\
4 \\
5 \\
6 \\
7\end{array}$ & $\begin{array}{l}\text { Inatalled Generating Capacity-Nameplate-MT } \\
\text { Net Generation, Million Kilowatt-houra } \\
\text { Plant Factor, Percent, Based on Nameplate Rating } \\
\text { Peak Deand on Plant. Megavate ( } 60 \text { Minutes) } \\
\text { Net Continuous Plant Capability. Megavate: } \\
\text { (a) When not Lieited by Condenaer Water } \\
\text { (b) When Limited by Condenaer Water }\end{array}$ & \multicolumn{2}{|c|}{$\begin{array}{r}137.5 \\
555.7 \\
46 \\
126.4 \\
147.0 \\
147.0\end{array}$} & \multicolumn{2}{|c|}{\begin{tabular}{rr|}
510.5 & $1 /$ \\
$2,785.7$ & \\
523.9 & \\
504.0 & \\
$\mathrm{KR}$ & \\
\end{tabular}} & \multicolumn{2}{|c|}{$\begin{array}{r}186.0 \\
679.3 \\
42 \\
209.5 \\
192.0 \\
\end{array}$} & \multicolumn{2}{|c|}{$\begin{array}{r}140.0 \\
166.9 \\
14 \\
154.0 \\
151.0 \\
\mathrm{KR}\end{array}$} \\
\hline $\begin{array}{r}8 \\
9 \\
10 \\
11\end{array}$ & $\begin{array}{l}\text { COST OF PLANT: (Thousands of Dollers) } \\
\text { Lond and Land Rights } \\
\text { Structures and Improvements } \\
\text { Equipment }\end{array}$ & \multicolumn{2}{|c|}{$\begin{array}{r}613 \\
3,418 \\
13,061 \\
\end{array}$} & \multicolumn{2}{|c|}{$\begin{array}{r}143 \\
16,816 \\
46,637 \\
\end{array}$} & \multicolumn{2}{|c|}{$\begin{array}{r}291 \\
3,453 \\
11,641 \\
\end{array}$} & \multicolumn{2}{|c|}{$\begin{array}{r}9 \\
2,637 \\
10,019\end{array}$} \\
\hline $\begin{array}{l}12 \\
13\end{array}$ & $\begin{array}{l}\text { Total Coat } \\
\text { Coat per Kilowat of Inatalled Copacity }\end{array}$ & \multicolumn{2}{|c|}{$\begin{array}{r}17,092 \\
124\end{array}$} & \multicolumn{2}{|c|}{$\begin{array}{r}63,596 \\
125\end{array}$} & \multicolumn{2}{|c|}{$\begin{array}{r}15,385 \\
83\end{array}$} & \multicolumn{2}{|c|}{$\begin{array}{r}12,665 \\
90\end{array}$} \\
\hline 14 & PRODUCTION EXPENSES: & $\$ 1000$ & $\underset{k \in b}{M i l l .}$ & $\$ 1000$ & $\underset{x=h}{M i 11 .}$ & $\$ 1000$ & $\underset{k=h}{M i l l, ~}$ & $\$ 1000$ & $\underset{k=h}{M i l 1 .}$ \\
\hline $\begin{array}{l}15 \\
16 \\
17 \\
18 \\
19 \\
20\end{array}$ & $\begin{array}{l}\text { Operation Labor. Superviaion and Engineering } \\
\text { Operation Supplies and Expenses. Incl. Water } \\
\text { Maintenance (Labor, Material, and Expenaes) } \\
\text { Renta } \\
\text { Stean from Other Sources or Stean Tranaferred } \\
\text { Joint Expensea }\end{array}$ & $\begin{array}{r}424 \\
68 \\
361 \\
(23) \\
(10)\end{array}$ & $\begin{array}{l}.77 \\
.12 \\
.65 \\
(.04) \\
(. \infty 2)\end{array}$ & $\begin{array}{l}581 \\
136 \\
465 \\
(3)\end{array}$ & $\begin{array}{r}.21 \\
.05 \\
.16\end{array}$ & $\begin{array}{r}388 \\
49 \\
277\end{array}$ & $\begin{array}{l}.57 \\
.07 \\
.41\end{array}$ & $\begin{array}{r}441 \\
43 \\
377 \\
2\end{array}$ & $\begin{array}{r}2.64 \\
.26 \\
2.26 \\
.01\end{array}$ \\
\hline $\begin{array}{l}21 \\
22 \\
\end{array}$ & $\begin{array}{l}\text { Total, Exclusive of Fuel } \\
\text { Fuel }\end{array}$ & $\begin{array}{r}820 \\
3,424 \\
\end{array}$ & $\begin{array}{l}1.48 \\
6.16 \\
\end{array}$ & $\begin{array}{l}1.179 \\
8,801 \\
\end{array}$ & $\begin{array}{l}0.42 \\
3.16 \\
\end{array}$ & $\begin{array}{r}714 \\
2,918 \\
\end{array}$ & $\begin{array}{l}1.05 \\
4.30 \\
\end{array}$ & $\begin{array}{r}863 \\
1,089\end{array}$ & $\begin{array}{l}5.17 \\
6.52\end{array}$ \\
\hline 23 & Total Production Expenses & 4,244 & 7.64 & 9,980 & 3.58 & 3,632 & 5.35 & 1,952 & 11.69 \\
\hline 24 & Production Expenses (except fuel) per Kilowat & \multicolumn{2}{|c|}{5.96} & \multicolumn{2}{|c|}{-} & \multicolumn{2}{|c|}{3.83} & \multicolumn{2}{|c|}{6.16} \\
\hline
\end{tabular}

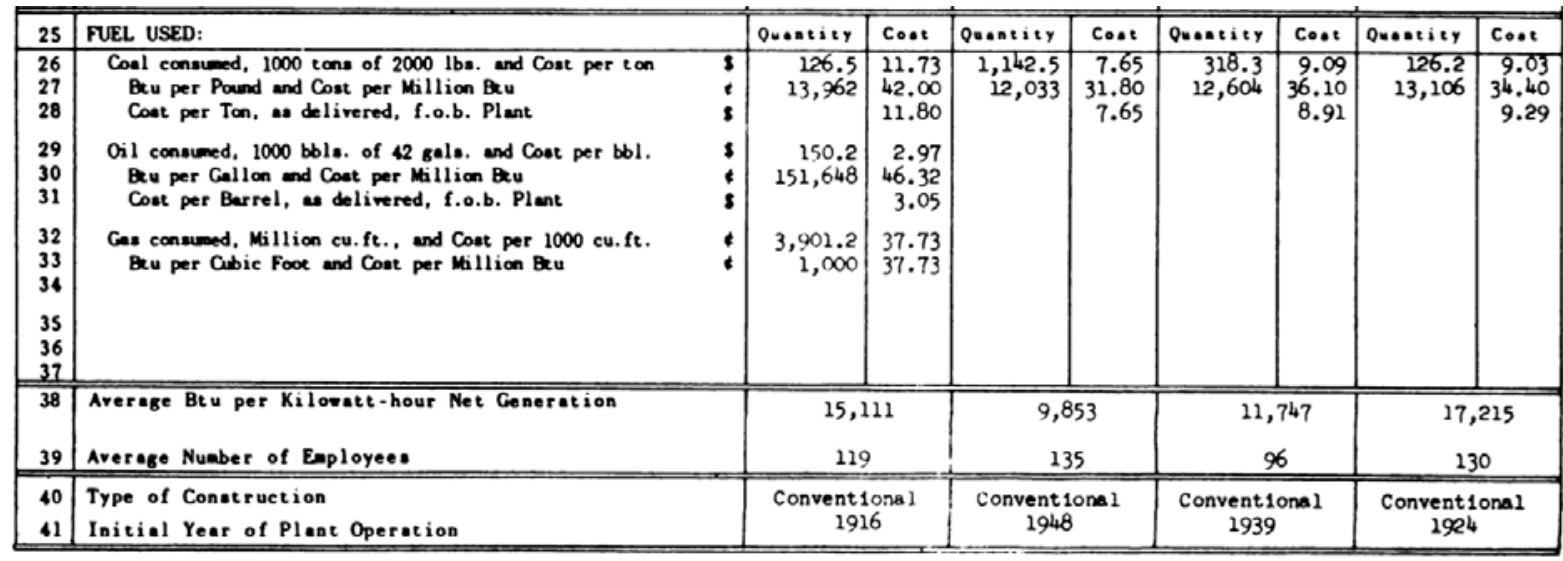

CHANGES OR ADDITIONS IN 195

\begin{tabular}{|c|c|c|c|c|c|c|c|c|c|c|c|c|c|}
\hline \multicolumn{7}{|c|}{ TURBO - GENERATOA CHARACTERISTICS } & \multicolumn{7}{|c|}{ BOILER CHLAACTERISTICS } \\
\hline Unite & $m$ & P.F. & P.S.t. & A.P.M. & Kv. & Yo.r & No. & $\begin{array}{l}\text { Poo lbs: } \\
\text { Por Howi }\end{array}$ & P.S.1. & Heat F. & Romet F. & Fuel & Yeor \\
\hline 1 & 156.2 & 85 & $\begin{array}{r}2,000 \\
\text { (Added }\end{array}$ & $\begin{array}{r}3,600 \\
\text { March, }\end{array}$ & $\begin{array}{c}18.0 \\
957)\end{array}$ & 1957 & 1 & $1,050.0$ & 2,300 & 1,050 & 1,000 & Pulv. Coul & 1957 \\
\hline
\end{tabular}




\section{B.3 AP3 model and counterfactuals}

\section{B.3.1 The AP3 model and $\mathrm{SO}_{2}$ emissions}

To examine the tradeoffs of coal fired power generation and a number of counterfactual scenarios, we use the air quality modelling embedded in AP3. The AP3 is a reduced-form integrated assessment model developed by Muller and Mendelsohn (2007, 2009) that links emissions of air pollution to exposures, physical effects, and monetary damages in the contiguous United States. This model has been widely used by researchers in economics and other fields, with publications in leading economic and general interest journals such as Michalek et al. (2011); Fowlie, Knittel and Wolfram (2012); Sandler (2012); Holland et al. (2016), and Sanders and Barreca (2021).

The air quality modeling module of AP3 makes use of a source-receptor matrix framework. That is, the marginal contribution of emissions in a source county ( $s$ ) to the ambient concentration in a receptor county $(\mathrm{r})$ is represented as the $(\mathrm{s}, \mathrm{r})$ element in a matrix. The source-receptor matrix requires emissions measured in grams per second $(\mathrm{g} / \mathrm{s})$, and produces air pollution concentration in micrograms per cubic meter $(\mathrm{g} / \mathrm{m} 3)$. We consider the AP3 scenario in which emissions arise from low point sources (effective height of less than 250 meters). The effective stack height is the sum of the actual physical height of the top of the smokestack, plus any plume rise. We had presented evidence in Appendix Figure A.2 that the average smokestack in our period of analysis was around 75 meters.

Our focus is on $\mathrm{SO}_{2}$ emissions, which the AP3 uses as inputs to produce estimates of atmospheric sulfates. $\mathrm{SO}_{2}$ emissions are a marker for the pollution produced by coal-fired power plants. In fact, in 1960 power plants produced $43 \%$ of $\mathrm{SO}_{2}$ emissions. In 1970 that number was $57 \%$ (NRC, 1975, Table 6-2, p.239). Atmospheric sulfates are an important component of particulate matter, which has been shown to harm human health. The U.S. EPA estimated the share of sulfates to be about a third of fine particulates (PM2.5) in 2003, when several policies to curb $\mathrm{SO}_{2}$ emissions were already in place (USEPA, 2004). Sulfates are derived principally from atmospheric transformations of gaseous $\mathrm{SO}_{2}$. Newman (1980) reviews historical and contemporaneous power plant and smelter plume studies examining the atmospheric oxidation of $\mathrm{SO}_{2}$. He concludes that "the average rate of oxidation of $\mathrm{SO}_{2}$ in plumes entering into and mixing with clean air is generally less than $1 \%$ per hour but with polluted urban air the rate can be at least twice as fast" (p.1).

$\mathrm{SO}_{2}$ emissions are estimated based on the total coal consumption that we have collected for each power plant in each year. We use the emission factors for coal-fired plants compiled by Smith and Gruber (1966) from the published literature and other sources up to the mid-1960s, which should reflect the combustion processes that determined the magnitude of air pollutant emissions of the power plants in our dataset.

Since the type of coal used in any area being studied is important, it is necessary to have information on coal distribution and utilization. The bituminous coal and lignite fields are organized into 23 producing districts as defined in the Bituminous Coal Act of 1937. Smith and Gruber (1966) provide information on the distribution of bituminous coal and lignite to the various states in 1962 from all districts of origin, and the percentage of coal supplied by each district.

The composition of the coal used in each state combined with the emission factors established in the 1960s and our plant-level coal consumption data aggregated at the county level allow us to estimate the county-level emissions of $\mathrm{SO}_{2}$. The AP3 uses these emissions as inputs to estimate air concentrations of sulfates. 


\section{B.3.2 The AP3 model over 1938-1962}

The AP3 model uses wind data to map emissions to ambient concentrations and so is not specific to a particular time period. The model is, however, typically used for studies in the contemporary period. We provide three pieces of evidence on its ability to produce estimates for our period. First, using monitor data for TSP and $\mathrm{SO}_{2}$ for 1957-1969, we compare the correlation between TSP and $\mathrm{SO}_{2}$ with the correlation between TSP and the AP3 estimate of sulfates. Second, we evaluate whether the AP3-derived sulfates are systematically related to color of the feathers of birds in the northern United States, an alternative measure of pollution available for the entire period of our analysis. Third, we show that the nationwide share of $\mathrm{SO}_{2}$ emissions by coal-fired power plants is very similar to the correlation between monitor data for $\mathrm{SO}_{2}$, which captures emissions from all sources, and our AP3-derived measures of atmospheric sulfates based on coal consumption by power generation.

The correlation between TSP and $\mathrm{SO}_{2}$ and the correlation between TSP and the AP3 estimate of sulfates is very similar. Before the passage of the Clean Air Act of 1970, TSP and $\mathrm{SO}_{2}$ were measured by a sparse network of pollution monitoring stations. The data was obtained through a FOIA request at the U.S. EPA and cover the period 1957-1969. The first correlation is 0.29, with 522 monitor-year observations. The second correlation is $0.24(\mathrm{~N}=2,753)$. Interestingly, the first correlation remains stable in the first decade of the Clean Air Act $(0.26, \mathrm{~N}=5,896)$, as expected. On the other hand, the second correlation decreases to $0.04(\mathrm{~N}=11,174)$, suggesting that our AP3derived measure of sulfates captures the strategies taken by power plants to curb $\mathrm{SO}_{2}$ emissions in response to the Clean Air Act.

AP3-derived sulfates are systematically related to color of the feathers of birds in the northern United States. DuBay and Fuldner (2017) use photometric reflectance data of over 1,300 bird specimens drawn from natural history collections to track relative ambient concentrations of atmospheric black carbon between 1880 and 2015 within the U.S. Manufacturing Belt, a region historically reliant on coal and dense with industry. Restricting the sample of bird specimens with information for our period of analysis (1938-1962), we have 194 specimens in 32 counties. In a simple regression model at the bird level controlling for year fixed effects because of the changes in the share of coal used by electricity generation over our period of analysis (see Figure 1), the coefficient of sulfates is statistically significant at the $0.1 \%$ level. A standard deviation increase in our measure of sulfates raises the feather-derived pollution measure by about a quarter of a standard deviation. This is consistent with the share of coal consumption by electric utilities depicted in Figure 1. It was less than 0.2 in 1950 , but over 0.4 by 1960 . Similarly, it is consistent with the contribution of coal-fired power generation for the nationwide emissions of $\mathrm{SO}_{2}$, which have been estimated to be about $23 \%$ in 1950 and 44\% in 1960 (Cavender, Kircher and Hoffman, 1973).

The AP3-derived measure of atmospheric sulfates tracks $\mathrm{SO}_{2}$ concentrations associated with emissions by coal-fired power plants. In 1960, electric utilities used about $44 \%$ of the total coal consumption in the United States and produced about $44 \%$ of the nationwide emissions of $\mathrm{SO}_{2}$ (Cavender, Kircher and Hoffman, 1973). The correlation between monitor level $\mathrm{SO}_{2}$ concentrations between 1958-1962 and our AP3-derived measure of sulfates is 0.38. One limitation is that the number of monitor-year observations is 40 . If we add a couple of years, which increases the number of monitor-year observations to over a hundred, that correlation increases to 0.42 . 


\section{B.3.3 Empirical analysis and counterfactuals}

We use the AP3 generated measure of sulfates to do empirical analysis and conduct counterfactuals. We define a 60-mile buffer surrounding the plant as the treated area and run a difference-indifferences specification examining Post Plant Opening and the interaction Post Plant Opening $\mathrm{x}$ Local Pollution Exposure, all evaluated relative to control counties 60 to 90 miles away. We use the 60-mile buffer because Lewis (2018) has estimated that households benefit from electricity access over the period 1940-1960 if they reside up to 60 miles from a power plant. Transmission constraints usually preclude households living farther than 60 miles from obtaining access. We use the control counties in the ring 60-90 miles for consistency with our other approach.

In Table 7, the "Post Plant Opening" variable captures the health benefits of electrification with no additional pollution, and the interaction term identifies the harmful effects of air pollution. These two parameters are at the heart of the tradeoff between electricity access and local air pollution. The estimated coefficient for Post Plant Opening is -0.4985, and for Post Plant Opening x Local Pollution Exposure 0.4410. Both are statistically significant and in the expected direction. The main effect is negative, indicating that electrification reduces infant mortality, and the interaction effect is positive, indicating that local pollution exposure may undo the benefits of electrification. The coefficients are used to plot the tradeoff in Figure 7.

With the AP3 we conduct the three counterfactuals: 1) installation of tall smokestacks (at least 200 meters tall), 2) replacement of coal plants with hydroelectric dams, and 3) installation of baghouses, an emission control technology. For comparability, all monetary values have been converted to 1990 dollars.

Suppose the U.S. government mandated that power plant smokestacks were at least 200 meters tall. The 200-meter height is more than double the average height in the period of our analysis (75 meters), but the technology to build them had already been developed by the late 1940s (see Appendix Figure A.2 for the tallest smokestack in each year during our study period). The 200meter height is also the prevalent height of power plant smokestacks in operation in the United States since the 1980s (Trimble, 2011). It is important to recall, however, that the effective stack height is the sum of the actual physical height of the top of the stack, plus any plume rise. A contemporaneous study for the Tennessee Valley Authority (TVA) area showed the at low wind speeds the effective height could more than double the physical height (Thomas, Carpenter and Gartrell, 1963). Thus, for our tall smokestack counterfactual, we rely on historical calculations comparing ground-level sulfur dioxide concentrations based on an effective height of 500 versus 100 meters (USHEW, 1968). Those calculations show that sulfur dioxide concentrations would be reduced by over $95 \%$ throughout the dispersion area. The rate of conversion between sulfur dioxides and sulfates is approximately linear for low levels of sulfur dioxide concentrations, and theoretically concave for medium and high concentrations, although the level at which nonlinearities set in was not known at least up to 1975 (NRC, 1975, p.xxxv) ${ }^{54}$ We assume a one-to-one relationship in our calculations based on the patterns of the correlation between historical measures of sulfur dioxide concentrations and the AP3-derived measures of sulfates, as discussed above.

Taking the reduction in average sulfate levels in counties treated by electrification driven by coal-fired power plants, together with the average number of births in those counties, our backof-the-envelope calculations suggest that 1,709 infant lives per year would have been saved by a

\footnotetext{
${ }^{54} \mathrm{NRC}(1975)$ argued against this strategy because [t] he application of tall stacks ... will not reduce total emissions of sulfur oxides to any significant degree; thus, this strategy does not decrease the total amount of sulfate in the regional atmosphere. The potential for increasing ambient sulfate concentrations in downwind areas should be carefully considered in advance, and effects on ambient concentrations monitored, if such a strategy is implemented.
} 
mandate of tall smokestacks on coal plants. The operating and capital costs of tall smokestacks were 0.27 to $0.4 \mathrm{mill} / \mathrm{kwh}$ and $\$ 10$ to $\$ 26 / \mathrm{kw}$ (1990 USD), respectively. In these calculations, we assume that the lifespan of stacks is approximately 40 years, which is the typical lifespan of a coalfired power plant. We also assume the realized electricity generation during our sample period, as opposed to the potential generation associated with the total electricity generating capacity. Lastly, we assume that the totality of the capacity installed over our study period would be covered by this pollution abatement strategy. Our back-of-the-envelope calculations imply that the cost per infant life saved associated with operational smokestacks would be about $\$ 520,000$. This is an ambitious scenario, but even in such a case, installation of tall smokestacks would have passed a cost-benefit analysis using the $\$ 1$ million value of a statistical life estimated for the period by Costa and Kahn (2004).

The second counterfactual exercise regards the displacement of coal by the hydroelectric dams that ended up being built in the post-1962 period. If electrification had been fueled by hydropower, no air pollution would have been produced in electricity generation, so there would be no health tradeoff. In this case, 1,035 infant lives would have been saved per year. Using the 2010 data from the EPAs Emissions \& Generation Resource Integrated Database (eGRID), we observe that about 75 percent of the coal-fired electricity generating capacity developed in our period of analysis 19381962 could have been replaced by hydroelectric capacity (including pumped storage). Nevertheless, the 75th percentile of distance from the hydro dams to the counties that built coal plants was about 250 miles. Therefore, assuming that the levelized cost of electricity was similar for coal and hydro, as it is the case today (USEIA, 2021), hydro would still be more expansive because it would require the construction of transmission lines to bring electricity to the original county with coal plants, and it would incur in transmission losses. The maximum transmission voltages in the United States in 1954 was $345 \mathrm{kv}$ (FPC, 1964, p.14). The representative investment per mile of $345 \mathrm{kv}$ transmission line, including right-of-way, was $\$ 324,641.94$ (FPC, 1964, p.151). We assume the lifespan of transmission lines is approximately 40 years. Transmission losses per 100 miles are estimated to be 4.1 percent, and electricity prices in 1960 were about $\$ 0.01$ (USEIA, 2011, Table 8.10). For the 194 coal plants that were less than 250 miles from hydroelectric dams, the average distance was 125 miles. Taking all this information into consideration, we calculate that the cost per life saved by the replacement of coal with hydroelectric dams is about $\$ 670,000$, again passing a cost-benefit analysis using the $\$ 1$ million value of a statistical life estimated by Costa and Kahn (2004).

In our third counterfactual, we consider mandating the installation of baghouses, a fabric filter technology still used today to control the emissions of particulate matter, but already available during our study period. About 1,781 infant lives would have been saved by such a mandate, and the cost per life saved would have been approximately $\$ 170,000$. Baghouses remove over 99 percent of particle pollution (USHEW, 1969), even fine particulates (PM2.5) (Turner et al., 1998). A reduction in average sulfate levels of the same magnitude implies the 1,781 infant lives saved per year if all coal plants installed baghouses. There are two primary costs associated with baghouses: installation costs and fly ash disposal. For a typical large power plant in our historical context, the installation costs, annualized over the expected 15-year lifespan, could range from $\$ 110,000$ to $\$ 750,000$ per year depending on the desired airflow (USHEW, 1969). The cost of fly ash disposal for electric utilities was $\$ 3.70$ per ton, and the typical power plant in the sample produced between 165,000 and 198,000 tons of fly ash per year. Thus, the annual cost of pollution abatement ranged from $\$ 720,000$ to $\$ 1.48$ million per plant. Hence, our back-of-the-envelope calculation suggest that the cost per life saved would have been between $\$ 109,000$ and $\$ 225,000$, with a midpoint of $\$ 170,000$. Of the three counterfactuals, this has the lowest cost per life saved. 
We summarize the key information from these three counterfactuals in Table 7. 